\title{
Subsurface stratigraphy of the Upper Devonian Bradford Group in the Greater Punxsutawney area, Pennsylvania
}

Anthony G. Johnson

West Virginia University

Follow this and additional works at: https://researchrepository.wvu.edu/etd

\section{Recommended Citation}

Johnson, Anthony G., "Subsurface stratigraphy of the Upper Devonian Bradford Group in the Greater Punxsutawney area, Pennsylvania" (2008). Graduate Theses, Dissertations, and Problem Reports. 4386. https://researchrepository.wvu.edu/etd/4386

This Thesis is protected by copyright and/or related rights. It has been brought to you by the The Research Repository @ WVU with permission from the rights-holder(s). You are free to use this Thesis in any way that is permitted by the copyright and related rights legislation that applies to your use. For other uses you must obtain permission from the rights-holder(s) directly, unless additional rights are indicated by a Creative Commons license in the record and/ or on the work itself. This Thesis has been accepted for inclusion in WVU Graduate Theses, Dissertations, and Problem Reports collection by an authorized administrator of The Research Repository @ WVU. For more information, please contact researchrepository@mail.wvu.edu. 
Subsurface Stratigraphy of the Upper Devonian Bradford Group in the Greater Punxsutawney Area, Pennsylvania

\author{
Anthony G. Johnson \\ Thesis submitted to the \\ Eberly College of Arts and Sciences \\ at West Virginia University \\ in partial fulfillment of the requirements \\ for the degree of
}

Master of Science

In Geology

\author{
Richard Smosna, Ph.D., Chair \\ Thomas Kammer, Ph.D. \\ Doug Reif, M.S. \\ Department of Geology and Geography \\ Morgantown, West Virginia \\ 2008
}

Keywords: Upper Devonian, Bradford Group, West-central Pennsylvania, Sequence stratigraphy, Bradford, Balltown

Copyright 2008 Anthony G. Johnson 


\section{ABSTRACT \\ Subsurface Stratigraphy of the Upper Devonian Bradford Group in the Greater Punxsutawney Area, Pennsylvania}

\section{Anthony G. Johnson}

The Upper Devonian Bradford Group of west-central Pennsylvania is a commonly targeted natural gas reservoir. The Greater Punxsutawney area covers parts of Jefferson, Indiana, and Clearfield counties, and within this area the Bradford Group is composed of nine separate drillers' sandstones. These sandstones are interpreted in outcrop to have been deposited in a range of depositional environments from sandy turbidites of the prodelta to muddy shoreface and sand-ridge complexes of the delta front. This study referenced gamma ray and bulk density e-logs from 269 wells to generate a data base from which maps and cross sections were generated for these beds in the subsurface, and allow for the application of sequence stratigraphic principles.

In this study, the Bradford Group is interpreted to be composed of two fourth order sequences. These sequences are subdivided into individual systems tracts based upon both the sequence stratigraphic surfaces observed in cross section and trends seen in map view. Porosity maps within the study area show that reservoir quality is generally influenced by the proximity of the sandstones to shoreline and dependent on the volume of lithic fragments which controls both the volume of primary porosity that was preserved during compaction as well as the volume of secondary porosity that might have been created by the dissolution of these lithic grains. 


\section{ACKNOWLEDGEMENTS}

I would like first like to thank the members of my committee for allowing me the use of their knowledge and understanding in order to complete this document and all of the work entailed. Especially, Dr. Smosna for his seemingly endless patience and understanding. Secondly, I would like to express my gratitude to Roy Lynch for the concepts and inspiration for this project as well as his guidance and leadership at the onset of my professional career. I would also like to thank both Dr. Allen and Dr. Matchen for inspiring me to pursue my interests in geology during my undergraduate years at Concord University.

My thanks also go out to those at Dominion E \& P, Inc. who have helped see me through this process. Rick Goings for his support and understanding of what this process has involved; Brenda Snyder for her enormous efforts in bringing me up to speed on both the collection and implementation of data for my study; and many others in the geology department who have lent me their advice and empathy.

Finally, and most importantly I would like to thank my family. Mom and Dad, I can never thank you enough for raising me right, and for all you have given to me. Thank you for your endless support, love, and guidance as I have ventured out into the world, and for allowing me to pursue my passion for the gas and oil business.

"Education without values, as useful as it is, seems rather to make man a more clever devil."-Clive Staples Lewis 


\section{TABLE OF CONTENTS}

$\begin{array}{lll}\text { ABSTRACT } & \text { ii }\end{array}$

$\begin{array}{ll}\text { ACKNOWLEDGMENTS } & \text { iii }\end{array}$

LIST OF FIGURES

INTRODUCTION 1

Area of Investigation 3

$\begin{array}{ll}\text { Methods of Investigation } & 7\end{array}$

GEOLOGIC SETTING AND BACKGROUND 14

DESCRIPTION AND INTERPRETATION OF BRADFORD ZONE 27

Kane Beds $\quad 30$

Third Bradford Beds 36

Second Bradford Beds $\quad 43$

First Bradford Beds $\quad 47$

T1 Shale Beds $\quad 53$

DESCRIPTION AND INTERPRETATION OF BALLTOWN ZONE 55

Balltown D Beds $\quad 58$

Balltown C Beds 64

Balltown B Beds $\quad 69$

Balltown A Beds $\quad 74$

Speechley Beds $\quad 79$

DESCRIPTION AND INTERPRETATION OF NET-PAY MAPS 84

$\begin{array}{ll}\text { CONCLUSIONS } & 95\end{array}$

$\begin{array}{ll}\text { REFERENCES } & 98\end{array}$ 


\section{LIST OF FIGURES}

Figure 1-Location of Study Area 4

Figure 2-Greater Punxsutawney Base Map 5

$\begin{array}{ll}\text { Figure 3-Greater Punxsutawney Structure } & 6\end{array}$

Figure 4-Gamma Ray and Bulk Density Curves of Balltown D 8 Sandstone in .LAS Format

Figure 5-Well \#37-065-24390 Balltown Zone 10

Figure 6-Well \#37-033-25824 Bradford Zone 11

Figure 7-Evolution of a Foreland Basin 15

Figure 8-Late Devonian Delta Systems 17

Figure 9-Acadian Clastic Wedge 19

Figure 10-Late Devonian Sea Level Curve 20

Figure 11-Stratigraphic Column of Bradford Group 21

Figure 12-Facies Map of Bradford Group and Stratigraphic Equivalents 23

Figure 13-Foreland Ramp Setting $\quad 24$

Figure 14-Devonian Stratigraphy of Council Run Field, 26 Centre and Clinton Counties

Figure 15-Isopach of Bradford Zone 28

Figure 16-Bradford Zone Net-sandstone Map 29

Figure 17-Kane Net-sandstone Map 31

Figure 18-A-A’ Dubois Dip Trending Bradford Zone Cross Section 32

Figure 19-B-B' McGees Mill Dip Trending Bradford Zone Cross Section 33

Figure 20-Kane Isopach Map 35

Figure 21—D-D' Southern Punxsutawney Dip Trending Bradford 37 Zone Cross Section 
Figure 22-C-C' Northern Punxsutawney Dip trending Bradford

Zone Cross Section

Figure 23-Third Bradford Net-sandstone Map

Figure 24-E-E' Strike Trending Bradford Zone Cross Section 40

Figure 25-Third Bradford Isopach Map $\quad 42$

Figure 26-Second Bradford Net-sandstone Map $\quad 44$

Figure 27-Second Bradford Isopach Map 46

Figure 28-First Bradford Net-sandstone Map $\quad 48$

Figure 29—Composite Core Graph of First Bradford (Murin, 1988) 50

Figure 30-First Bradford Isopach Map $\quad 52$

Figure 31-Isopach Map of the T1 Shale $\quad 54$

Figure 32-Isopach of Balltown Zone $\quad 56$

Figure 33-Balltown Zone Net-sandstone Map $\quad 57$

Figure 34-Balltown D Isopach Map $\quad 59$

Figure 35-Balltown D Net-sandstone Map $\quad 60$

Figure 36-A-A’ Dubois Dip Trending Balltown Zone Cross Section 62

Figure 37-C-C' Northern Punxsutawney Dip Trending Balltown 63 Zone Cross Section

$\begin{array}{lr}\text { Figure 38-Balltown C Isopach } & 65\end{array}$

Figure 39-Balltown C Net-sandstone Map 66

Figure 40-B-B' McGees Mill Dip Trending Balltown Zone Cross Section 68

$\begin{array}{lr}\text { Figure 41-Balltown B Net-sandstone Map } & 70\end{array}$

$\begin{array}{ll}\text { Figure 42_Balltown B Isopach Map } & 71\end{array}$

Figure 43-D-D’ Southern Punxsutawney Dip Trending Balltown 72 Zone Cross Section 
Figure 44-Balltown A Isopach Map $\quad 75$

Figure 45-Balltown A Net-sandstone Map 76

Figure 46-E-E’ Balltown Zone Strike Cross Section 77

Figure 47-Speechley Isopach Map $\quad 80$

Figure 48-Speechley Net-sandstone Map $\quad 81$

Figure 49-Drillers' Log of Well \#37-033-24694 82

$\begin{array}{lr}\text { Figure 50-Bradford Zone Net-pay map } & 85\end{array}$

Figure 51-Kane Net-pay $\quad 86$

Figure 52-Third Bradford Net-pay Map 86

$\begin{array}{ll}\text { Figure 53-Second Bradford Net-pay Map } & 87\end{array}$

$\begin{array}{lr}\text { Figure 54-First Bradford Net-pay Map } & 87\end{array}$

Figure 55-Balltown Zone Net-pay Map $\quad 89$

Figure 56-Balltown D Net-pay Map $\quad 90$

Figure 57-Balltown C Net-pay Map 90

Figure 58-Balltown B Net-pay Map $\quad 91$

Figure 59-Balltown A Net-pay Map $\quad 91$

Figure 60—Speechley Net-pay Map $\quad 92$

Figure 61-Bradford Group Net-pay Map $\quad 94$

Figure 62-Sequence Stratigraphic Diagram of the Upper Devonian 97 Bradford Group 


\section{INTRODUCTION}

Exploration and development of natural gas fields within the Appalachian basin have been a major part of Pennsylvania's history over the last century, and the Upper Devonian Bradford Group of west-central Pennsylvania is one of the more prolific reservoirs. Bradford sandstones have porosity values that range from 7-16\%, gas saturations as high as $83.2 \%$ (Laughrey et al.., 2004), and an estimated 250 billion cubic feet of recoverable gas (Gautier et al.., 1995). The reservoirs pinch out laterally creating stratigraphic traps within the surrounding Upper Devonian shales. The Bradford Group is located at a relatively shallow depth, about 2200-3600 feet within the study area, and wells have a relatively low drilling cost (about $\$ 300,000$ ). Collectively, these features make the Bradford Group one of the main targets for development within the Appalachian basin. However, the linear geometry of the sandstones make them a difficult target to locate and map in the subsurface.

Previous studies in the Appalachian basin have been lithostratigraphic in nature, interpreting the Bradford Group to have been deposited on a shallow muddy ramp. Specific facies include turbidite, slope, shelf, and muddy shoreface; the sediments were transported primarily by storm processes from eastern fluvial and estuarine systems (Walker, 1971; Glaeser, 1974, 1979; Woodrow and Isley, 1983; Craft and Bridge, 1987; Slingerland and Loule, 1988). Johnson et al.. (1985) used conodont biostratigraphy to define sea-level fluctuations across the Euramerican continent during Devonian time, and Boswell and Donaldson (1988) used their published sea-level curve to define major sequence-stratigraphic boundaries within the Appalachian basin, including those of the Bradford Group. However, little sequence-stratigraphic work has been done with respect 
to the Bradford Group. Previous lithostratigraphic correlations of the drillers' sandstones have led to inconsistent picks in the subsurface because of their laterally discontinuous nature. When these formations are identified in the subsurface, it is often done on the basis of stratigraphic order as they would appear in an ideal stratigraphic column. Therefore, if a particular sandstone is locally absent, the one below it in stratigraphic order may be named incorrectly. Thus sandstones can be misidentified, miscorrelated, and inaccurately mapped. The purpose of this study is to apply the concepts of sequence stratigraphy, as defined by VanWagoner et al. (1990) and Catuneanu (2006), to the Bradford Group of west-central Pennsylvania. This will allow for more accurate mapping of individual drillers' sandstones by using regionally correlative shales and other marker beds to identify and subdivide stratigraphic sequences. Accurate mapping of these sandstones will allow for interpretation of the depositional environment of the Bradford Group within the study area as well as improve stepout prospects and further development of target reservoir rocks by identifying sandstone trends in west-central Pennsylvania. 


\section{Area of Investigation}

The study area covers approximately 350 square miles of rural countryside in north-central Pennsylvania and is located within what is termed, for the purpose of this study, the Greater Punxsutawney Area (Figure 1). The Greater Punxsutawney area consists of the Luthersburg, DuBois, Reynoldsville, Punxsutawney, McGees Mill, and few other surrounding U.S.G.S. 7.5 minute topographic quadrangles. These are located within Jefferson, Indiana, and Clearfield Counties. Geologically, the study area is bound to the northwest by the Sabinsville (Boone Mountain) anticline, to the southeast by the Chestnut Ridge anticline, to the northeast by a lack of well control, and to the southwest by the encroachment of this study into a different study area as specified by Dominion E $\&$ P, Inc. (Figure 2). Structurally the study area is located within a broad, gently dipping syncline (Figure 3) on the Pennsylvanian Plateau province and lacks any complicated structure.

The study area, like much of Appalachia, is an area that has been actively developed for petroleum for many years and will continue to be developed for many more. New wells tend to be drilled on a spacing of 1000-1500 feet and are typically completed within Lower Mississippian and Upper Devonian strata. Within the study area the Bradford Group is located at a depth of 2200-3600 feet below the surface, and is typically the deepest unit penetrated. 


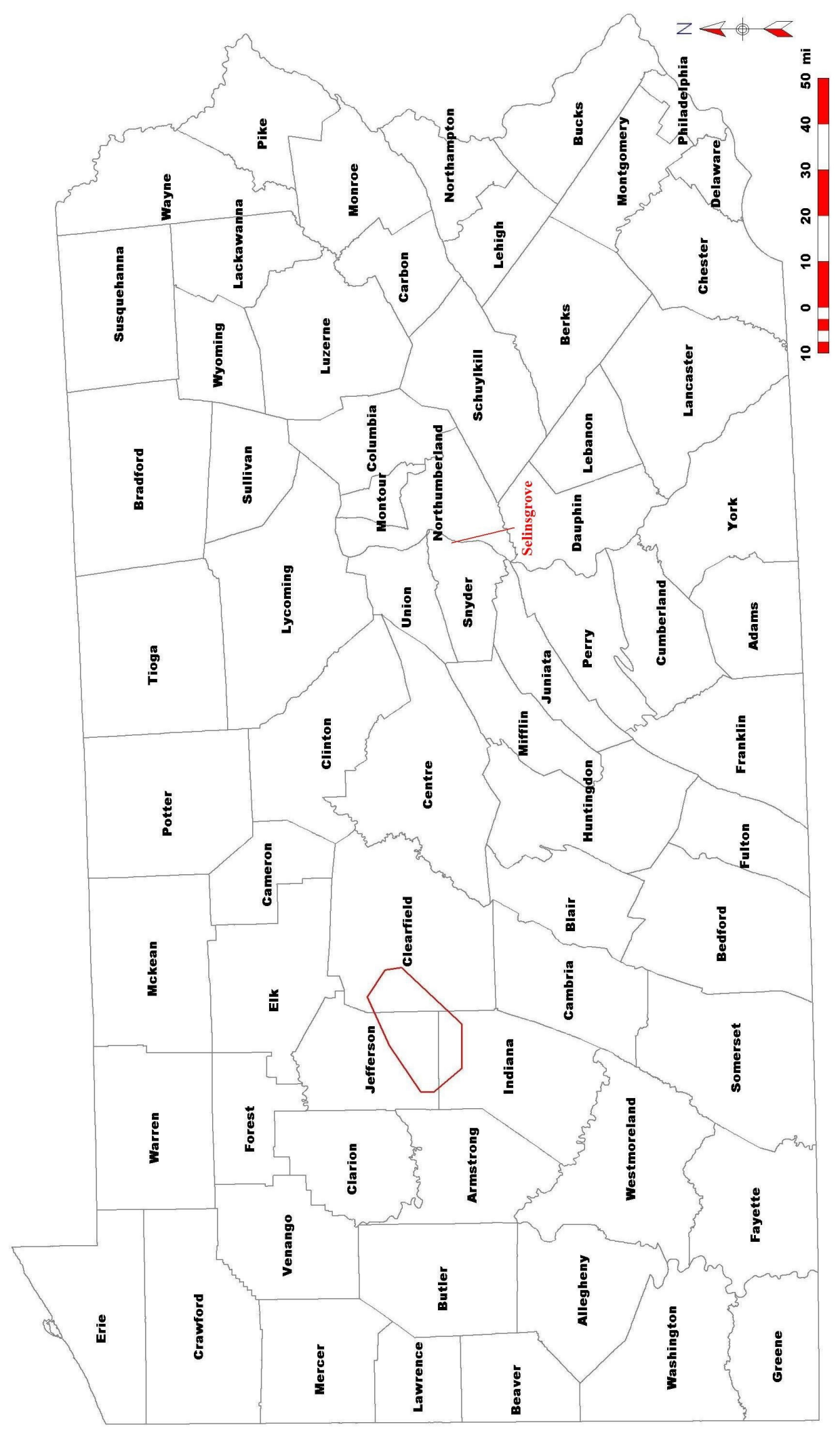

Figure 1-Location of Study Area 


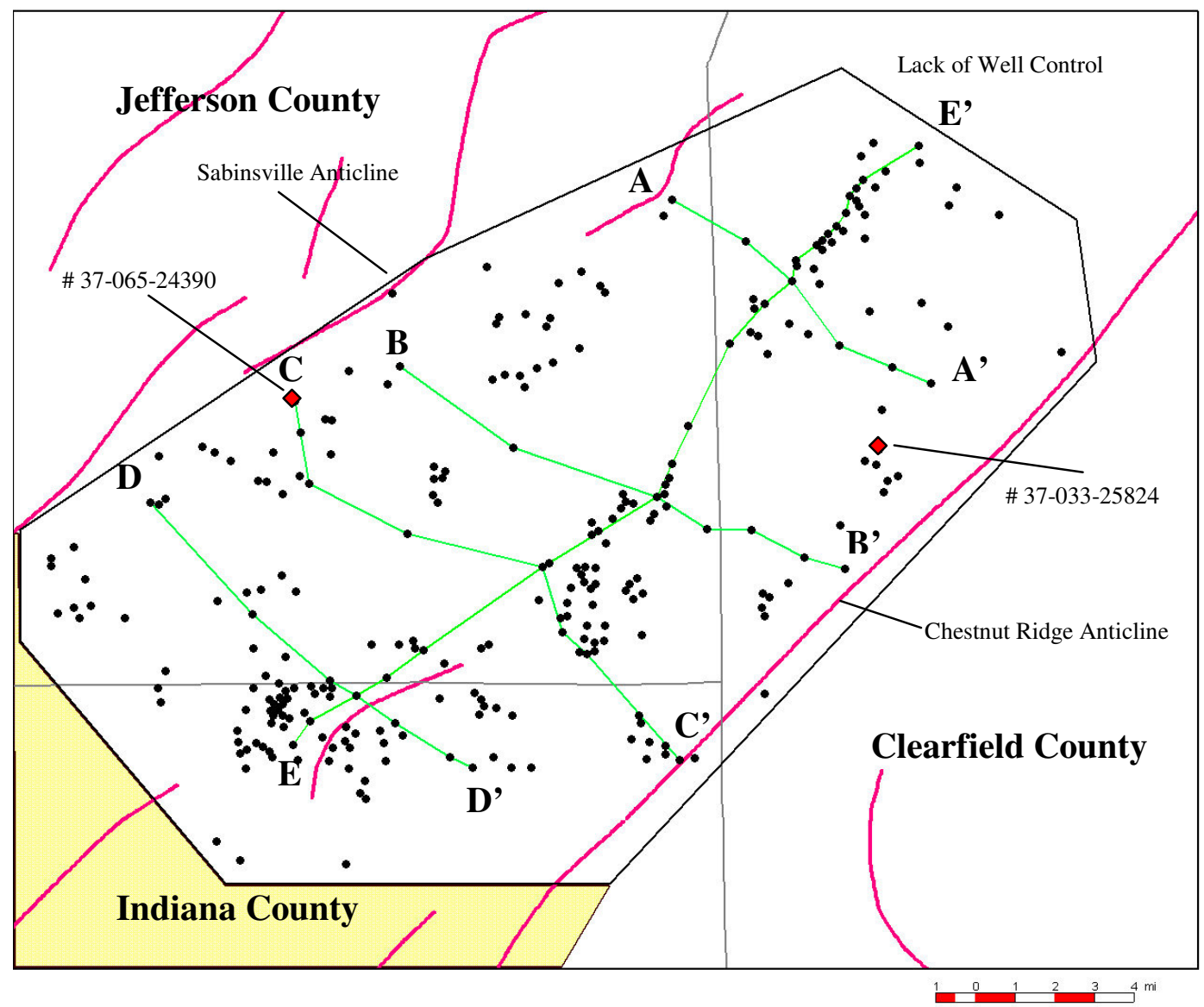

Figure 2-Greater Punxsutawney Base Map

$\underline{\text { Map Key }}$

Well

1) Type Section Wells (Figures 5 \& 6)

- Anticlinal Axis

Cross Section

— Field Area Boundary

County Border

Adjacent Field Area

\section{Cross Sections}

A-A' Dubois Cross Section

B-B' McGhees Mill Cross Section

C-C' North Punxsutawney Cross Section

D-D' South Punxsutawney Cross Section

E-E' Strike Cross Section 


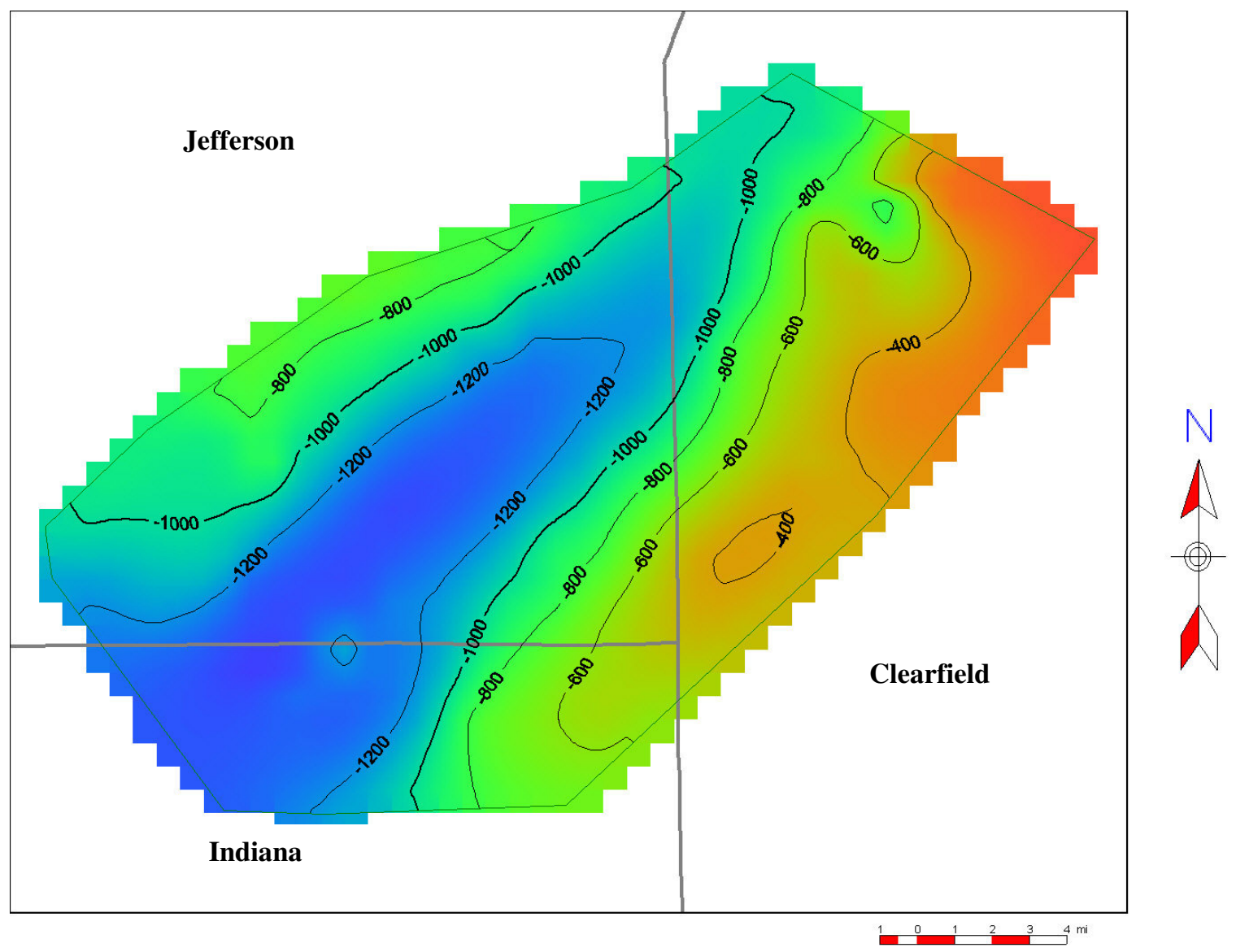

Figure 3-Greater Punxsutawney Structure

Geological structure of the Greater Punxsutawney Area as derived from the sub-sea level values for the top of the Speechley driller's sandstone. Blue indicates a structural low and red, a structural high. 


\section{Methods of Investigation}

The data set for this study consists of 269 gamma-ray and compensated bulkdensity logs in the Greater Punxsutawney Area (Figure 2), which were made available primarily by Dominion E \& P, Inc. Some additional logs needed to help establish well control were provided by the Pennsylvania Geological Survey’s web page (www.pairis.state.pa.us). The logs were compiled into GeoGraphix (GGX) and displayed as either a raster or digital image (.LAS file) (Figure 4). In order to do this, the paper copy of the logs had to be scanned and then either depth registered, to be displayed as a raster image, or digitized by hand, to be entered as a .LAS file. New well logs in the study area that were drilled during the course of this study were received from the service company as .LAS files and automatically entered into GGX. 


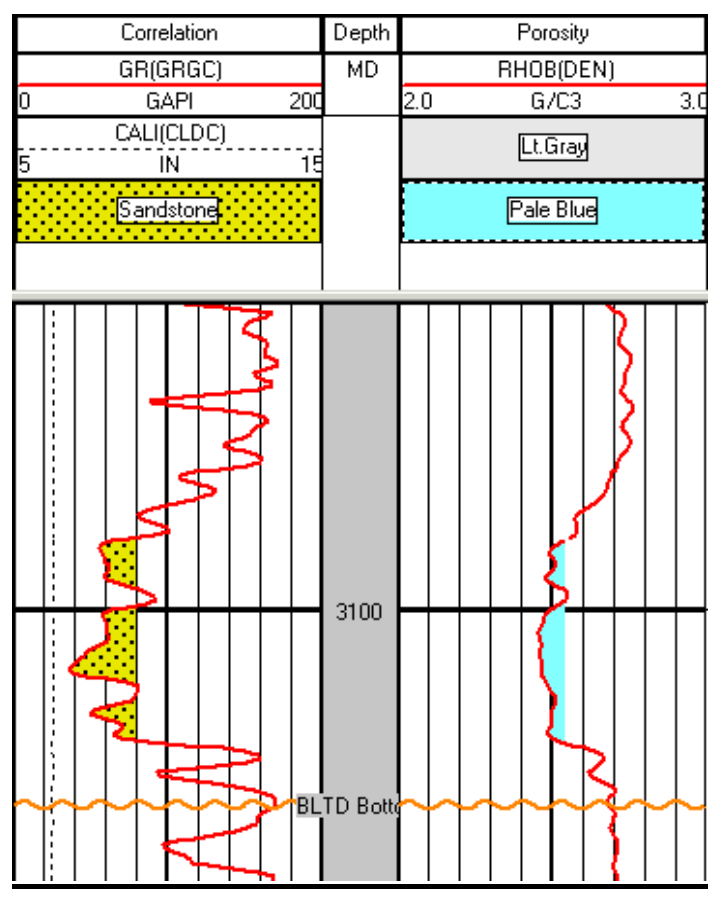

Figure 4-Gamma Ray and Bulk Density Curves of Balltown D Sandstone in .LAS Format

Yellow $=<80$ API Gamma Ray Units

Blue $=<2.55 \mathrm{~g} / \mathrm{cc}$ 
Once entered into GGX the well logs were opened in the cross section module, and stratigraphic picks (tops and bottoms) were made across the field for the individual drillers' sandstones of the Bradford Group. In an effort to eliminate misidentification of individual drillers' sandstones, known marker beds were used to help correlate picks across the study area (Figure 5 and 6). These include the sandstone at the base of the Bradford zone, a shale unit between the Balltown and Bradford sections with a high reading on the gamma ray logs (called the T1 marker bed), the sandstone at the base of the Balltown zone, and the high density unit (bulk-density log) at the top of the Balltown A drillers' sandstone. Within the finer intervals created by these picks, it was easy to accurately identify and correlate the individual drillers' sandstones. The drillers' sandstones were correlated across the field by opening multiple wells in the GGX cross section module and using shale beds as a guide for making picks of separate horizons. These shale beds are indicated by a higher API value on the gamma-ray track of the well $\log$, and they are more laterally extensive across the study area than the sandstones. These shale beds combined with the other known marker beds allowed for more consistent correlation, even in areas where individual sandstones are absent. 


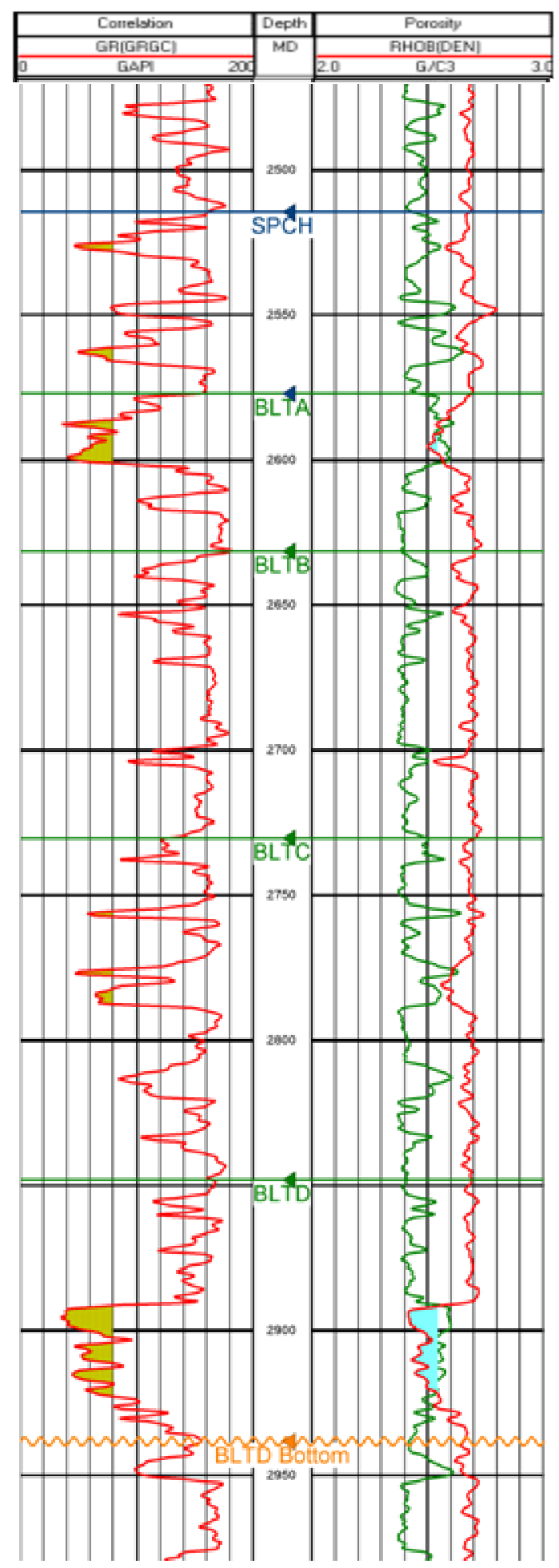

Abbreviation of Drillers' Sandstones

SPCH = Speechley

BLTA = Balltown A

BLTB = Balltown B

BLTC = Balltown C

BLTD = Balltown D

BLTD Bottom = Balltown D Bottom

Figure 5-Well \#37-065-24390 Balltown Zone

The area shaded yellow indicates rock with less than 80 API units (sandstone), and blue indicates a bulk density of less than $2.55 \mathrm{~g} / \mathrm{cc}(\Phi>7 \%)$. (Location of well shown on Figure 2) 


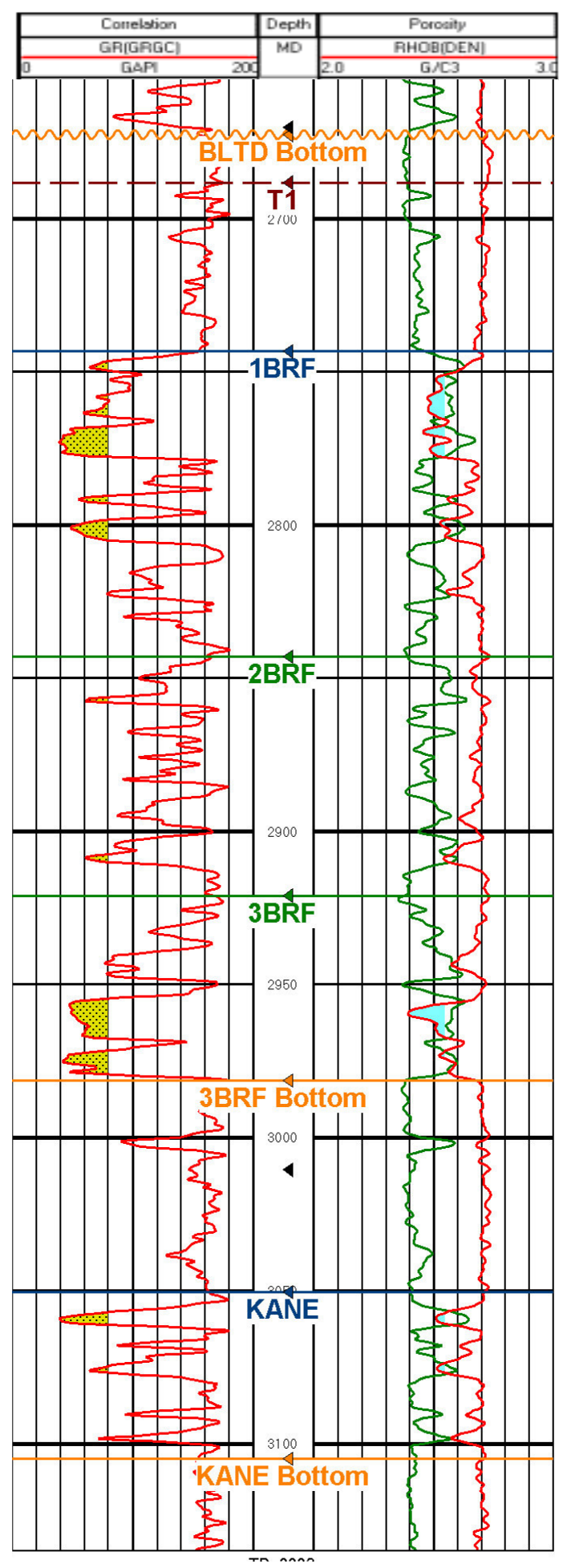

Abbreviation of Drillers' Sandstones

$$
\text { 1BRF }=\text { First Bradford }
$$

$2 \mathrm{BRF}=$ Second Bradford

3BRF $=$ Third Bradford

3BRF Bottom $=$ Third Bradford Bottom

KANE = Kane

KANE Bottom = Kane Bottom

Figure 6-Well \#37-033-25824 Bradford Zone

The area shaded yellow indicates rock with less than 80 API units (sandstone), and blue indicates a bulk density of less than $2.55 \mathrm{~g} / \mathrm{cc}(\Phi \geq 7 \%)$. (Location of well shown on Figure 2) 
With all of the picks completed, GGX was used to generate a series of maps based on net-sandstone values (isolith maps), net-pay values, and the total thicknesses between marker beds (isopach maps). Net-sandstone values were calculated from the gamma-ray curve. The gamma-ray reading is considered to be representative of sandstone where the value is 80 API gamma ray units or less on the curve. The total vertical section with less than 80 API units for each drillers' sandstone is then summed for that well (Figure 4). Likewise, the net-pay value is a measure of the total vertical section for each drillers' sandstone displaying a bulk density of $2.55 \mathrm{~g} / \mathrm{cc}$ or less. These rocks are considered to be porous enough ( $7 \%$ or greater) to allow for the economic storage of hydrocarbons. The isopach maps were generated using measured thicknesses of the Balltown and Bradford zones. The values for the Bradford zone isopach map were measured from the top of the First Bradford drillers' sandstone down to the base of the Kane drillers' sandstone. The Balltown zone isopach values were measured from the top of the Speechley drillers' sandstone to the base of the Balltown D drillers' sandstone.

The maps for this study were generated using the Isomapping software within GGX. The grid spacing for the maps was kept as small as necessary to allow GGX to accurately contour around all data points, but was also kept large enough to prevent common problems in computerized contouring, such as crossing contour lines. Generally, the grid space had a smallest feature radius of about 300 feet with a radius of influence of about 3000 feet, and used a minimum curvature gridding algorithm. Features such as bias trend and z-value projection were not used; therefore, the trends seen in these maps are accurately representative of the data. 
Cross sections constructed across the study area show the trends of sandstones in the dip and strike directions as well as vertical variation. Four dip-oriented and one strike-oriented cross section were spaced across the study area in a grid-like fashion (Figure 2). Each cross section was then split into the Bradford and Balltown zones in order to make them easier to see. This also showed well the continuity of the drillers' sandstones in the subsurface. GGX interpolated sandstone and shale bodies between wells and displayed them at an equal spacing rather than in true space.

The trends observed in the maps and in cross sections were used to locate sandstone deposits on the foreland ramp, to correlate between deposits of sandstone and porosity values, to display the relationships between chronostratigraphic surfaces, and to establish relative sea-level changes across the Greater Punxsutawney area. 


\section{GEOLOGICAL SETTING AND BACKGROUND}

During Late Devonian time the North American continent was located about 15 to 20 degrees south of the equator and had a warm subtropical climate with seasonably wet and dry conditions (Woodrow, 1985; Kent, 1985; van der Voo, 1988). Sediments of the Bradford Group are part of the Catskill clastic wedge and were the result of erosion of the highlands to the east (modern azimuth) that formed as the result of the Acadian Orogeny. The Acadian Orogeny was second of the three major orogenies that formed the Appalachian foreland basin, and was the result of the collision of Laurentia (proto-North American continent) with the Avalonian Island Arc (Hibbard in van der Pluijm and Marshak, 2004). This collision occurred about 410-360 million years ago and resulted in the accretion of the Avalon terrain onto the eastern margin of North America and uplift of the Acadian Highlands (Hibbard in van der Pluijm and Marshak, 2004). The downward flexure of the North American lithosphere, due to tectonic loading, allowed for the accumulation of sediment of the Catskill clastic wedge (Figure 7) (Quinlan and Beaumont, 1984). 


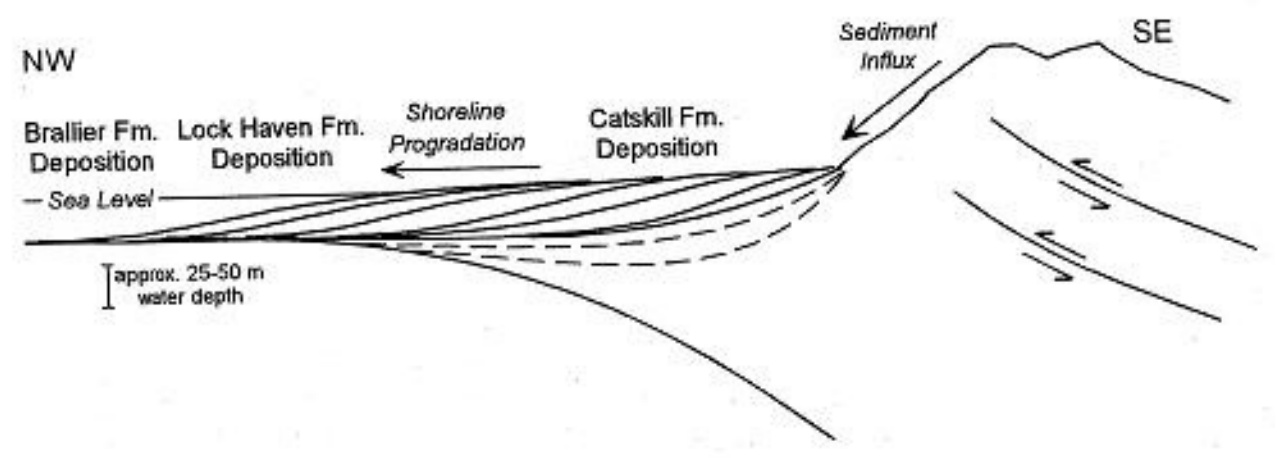

Figure 7-Evolution of a Foreland Basin

Subsidence of the foreland basin and the creation of accommodation space occurred because of tectonic loading of the Acadian fold-thrust belt plus sediment loading within the basin (Castle, 2000). 
The Appalachian basin, located between the Appalachian Mountains and the North American craton, is classified as a peripheral foreland basin. Peripheral foreland basins form on the cratonward side of a continent-to-continent collision (Allen and Allen, 2005). Immediately following the Acadian Orogeny, the basin was filled with sediments transported to the basin by a series of river systems (Sevon, 1985). These river systems began as braided streams in the Acadian Highlands and flowed westward across a broad, relatively flat alluvial plain. The streams increased in size, sinuosity, and competence as they merged and decreased in number to form more meandering patterns downslope (Sevon and Woodrow, 1985; Laughrey and Harper, 1986; Boswell and Donaldson, 1988). At the sea they deposited their sediment as part of one of many delta systems located on the foreland ramp (Boswell and Donaldson, 1988; Boswell and Jewell, 1988; Castle, 2000).

The foreland ramp of the Appalachian basin is seen to have had a large amount of accommodation space, both laterally and vertically, because of tectonic subsidence and eustacy which allowed for the deposition of a thick fine grained succession of rock without a definitive shelf break (Castle, 2001). Deltas that formed along this ramp were rather elongate in the seaward direction, laterally restricted, and separated by large muddominated interdeltaic regions (Dennison, 1985; Boswell and Donaldson, 1988). The influence of fluvial processes combined with significant tidal and wave modification dominated the shoreline of the foreland ramp (Woodrow et al.., 1988). During Late Devonian time there were four major delta systems that dominated the Catskill coastal plain (Figure 8). The Elk and Indiana delta systems in Pennsylvania were responsible for 
transport of sediment to the foreland ramp and development of the Bradford Group in the study area (Boswell and Donaldson, 1988; Boswell et al.., 1996).

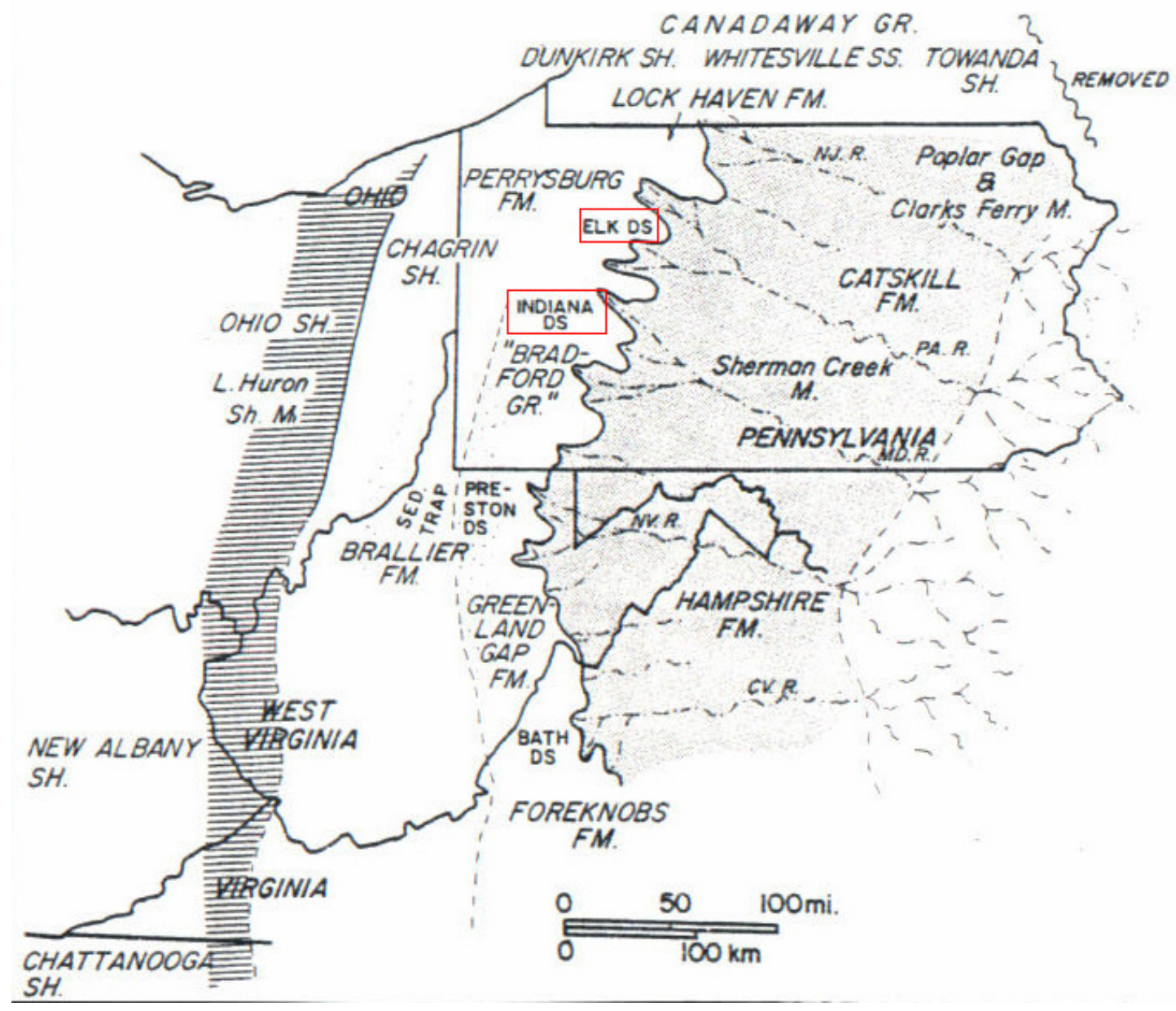

Figure 8-Late Devonian Delta Systems

The Elk and Indiana delta systems of Pennsylvania comprise the deposystems of the Bradford Group. DS = Delta System (Boswell and Donaldson, 1988) 
The Upper Devonian Bradford Group was deposited in the middle of the Catskill delta complex during Frasnian and Famennian time (Figure 9). The contact between the Frasnian and Famennian was marked by a 'rapid, short-lived regression' followed by a transgression and succeeding period of global cooling and glaciation during the Famennian (Johnson et al., 1985; Cecil et al., 2004). During this time tectonism was ending, and relative sea-level changes within the basin were controlled more by eustacy and sedimentation rate (Boswell and Donaldson, 1988; Castle, 2000; 2001). The curve of shoreline position (Boswell and Donaldson, 1988) shows the fourth-order trends of sealevel change during Late Devonian time (Figure 10). During this time eustatic sea-level was relatively high but beginning to fall. The Bradford group lies beneath the Venango group (including the Warren drillers' sandstones), above the Elk group (including the Riley), and contains nine separate drillers' sandstones (Figure 11). The drillers' sandstones are the most common terms used within west-central Pennsylvania for dividing the Bradford Group. From top to bottom these sands are the Speechley and Balltowns A-D (Balltown zone), and the first through third Bradfords and the Kane (Bradford zone) (Figures 5 and 6). 


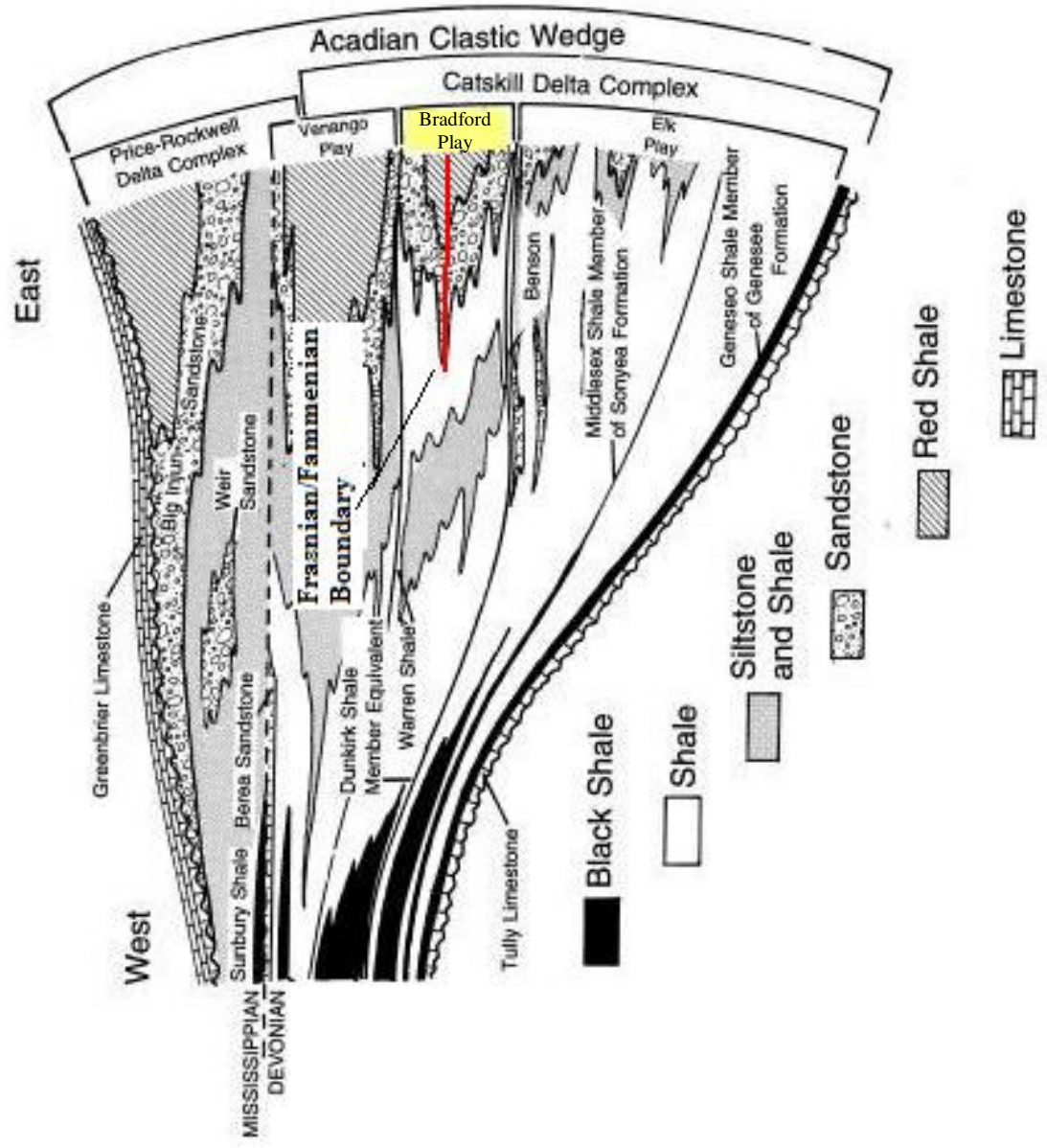

Figure 9-Acadian Clastic Wedge

Upper Devonian Bradford Group lies in the middle of the Catskill delta complex. (Modified from Boswell et al., 1996) 


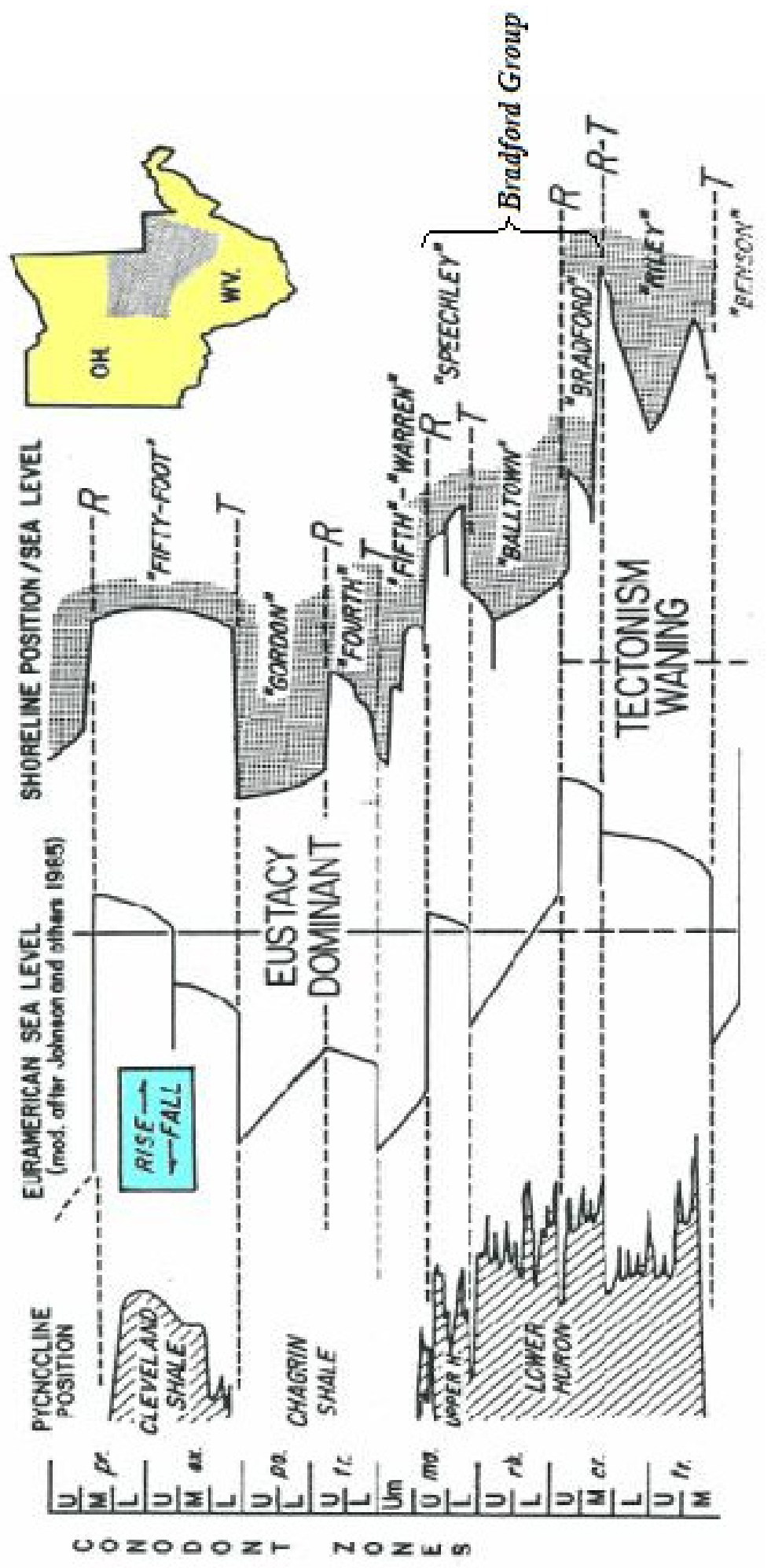

Figure 10-Late Devonian Sea Level Curve

The Bradford Group was deposited during a fourth-order fluctuation of relative sea-level when Acadian tectonism was waning. (Boswell and Donaldson, 1988; modified from Johnson et al., 1985) 

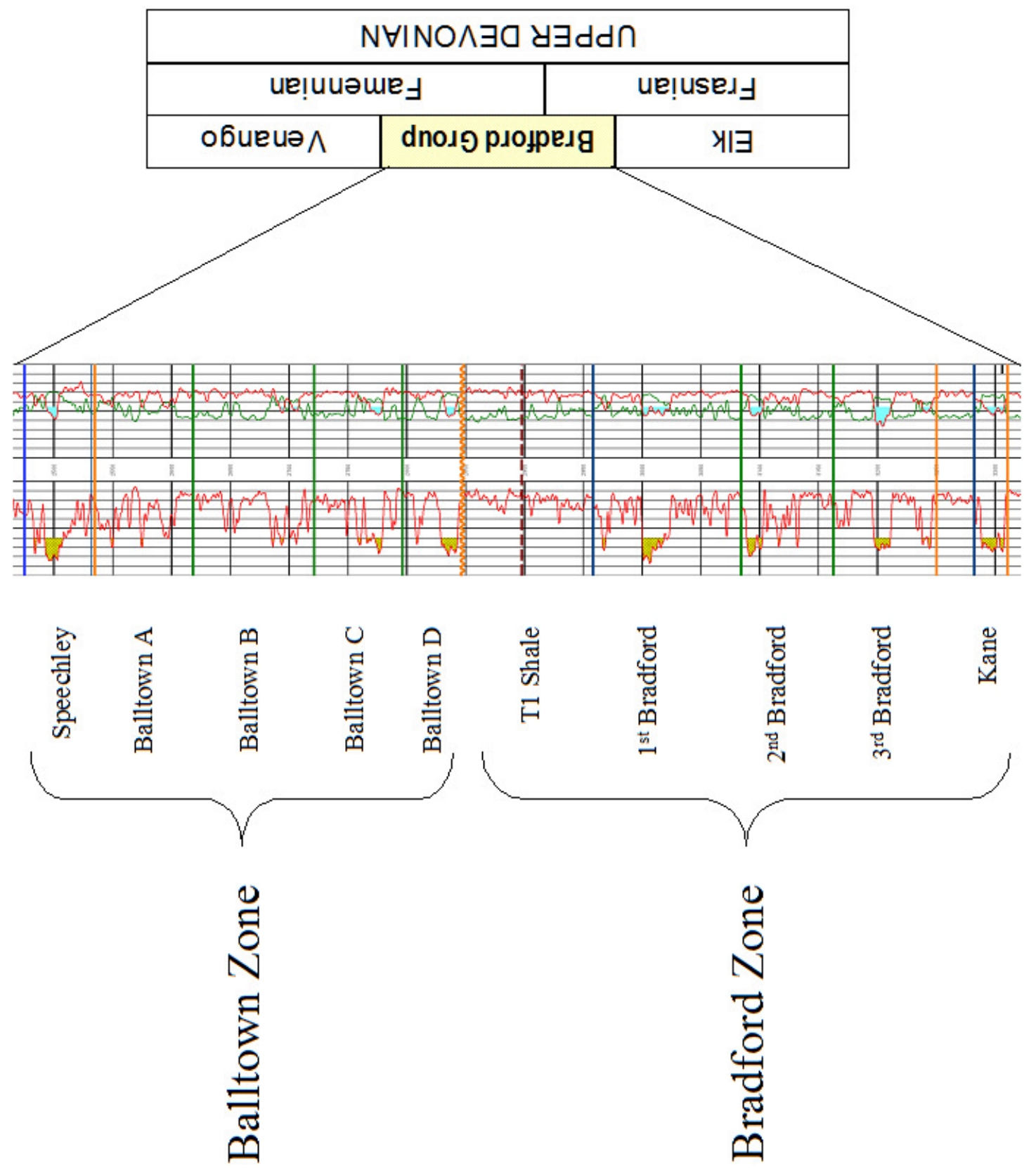

Figure 11-Stratigraphic Column of Bradford Group

Green lines on log mark shale beds used to pick individual drillers' sands, orange lines depict base of Bradford and Balltown zones, and blue lines represent the top of the zones. (Boswell et al., 1996) 
The Bradford Group correlates to the Lock Haven Formation in eastern outcrops of Pennsylvania and to the Scherr and Foreknobs Formations in West Virginia (Sevon and Woodrow, 1985; Woodrow et al., 1988; Warne and McGhee, 1991). Near Port Matilda, Centre County, PA, and Altoona, Blair County, PA, about 30 miles southeast of the study area, the Lock Haven Formation has been interpreted as having been deposited in shelf sand-ridge complex, ridge-margin, muddy-shoreface, tidal-flat, and estuarine environments (Slingerland and Loule, 1988; Warne and McGhee, 1991) (Figure 12). In the subsurface of Clinton and Centre counties, Smosna and Bruner (1997) interpreted the Bradford Group sandstones to be representative of distributary-mouth bars and offshore sand-ridges. Southeast of the study area the Kane sandstone was interpreted to be composed of distributary mouthbar and lower fluvio-deltaic plain deposits (Hussing, 1994). Southwest of the study area the Bradford Group is typically not recognized in the subsurface, and is composed primarily of siltstone and shale with the majority of sandstones in the section being thin and discontinuous (Laughrey and Harper, 1986). These rocks are typical of deeper water deposition than those of Clinton and Centre counties, and the Second Bradford sandstone is the only unit of the Bradford Group that is still mappable. The lack of sandstone to the southwest and west combined with more fluvial environments to the east indicate that within the study area the Bradford Group is representative of an intermediate or mid-ramp environment where turbidites and deltaic deposits are likely to accumulate (Figure 13). In fact, along strike, the First Bradford has been interpreted as longshore bars deposited along the delta front (Murin, 1988). 


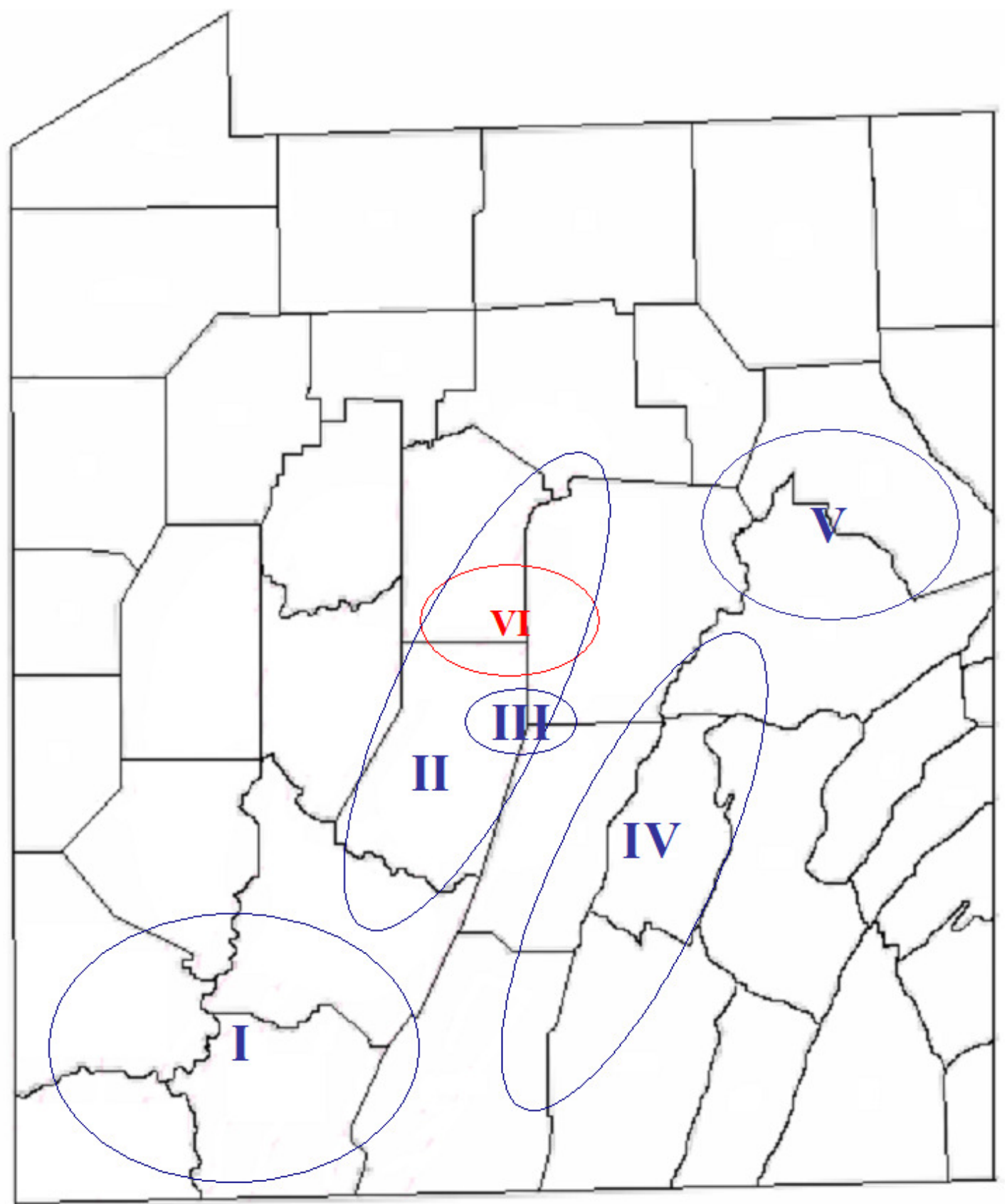

Figure 12--Facies Map of Bradford Group and Stratigraphic Equivalents

I. Laughrey and Harper (1986)—Bradford Group_-Sands pinch out due to lateral extent of Indiana delta system

II. Murin (1988)—First Bradford-Long-shore bars on delta front

III. Hussing (1994)_Kane-Distributary mouthbar and lower fluvio-deltaic plain

IV. Slingerland and Loule (1988); Warne and McGhee (1991)_Lock Haven-Shelf sandridge complex, ridge-margin, muddy-shoreface, tidal-flat, and estuarine environments

V. Smosna and Bruner (1997) — Lock Haven_Distributary mouth bars and off-shore sandridges.

VI. My study 


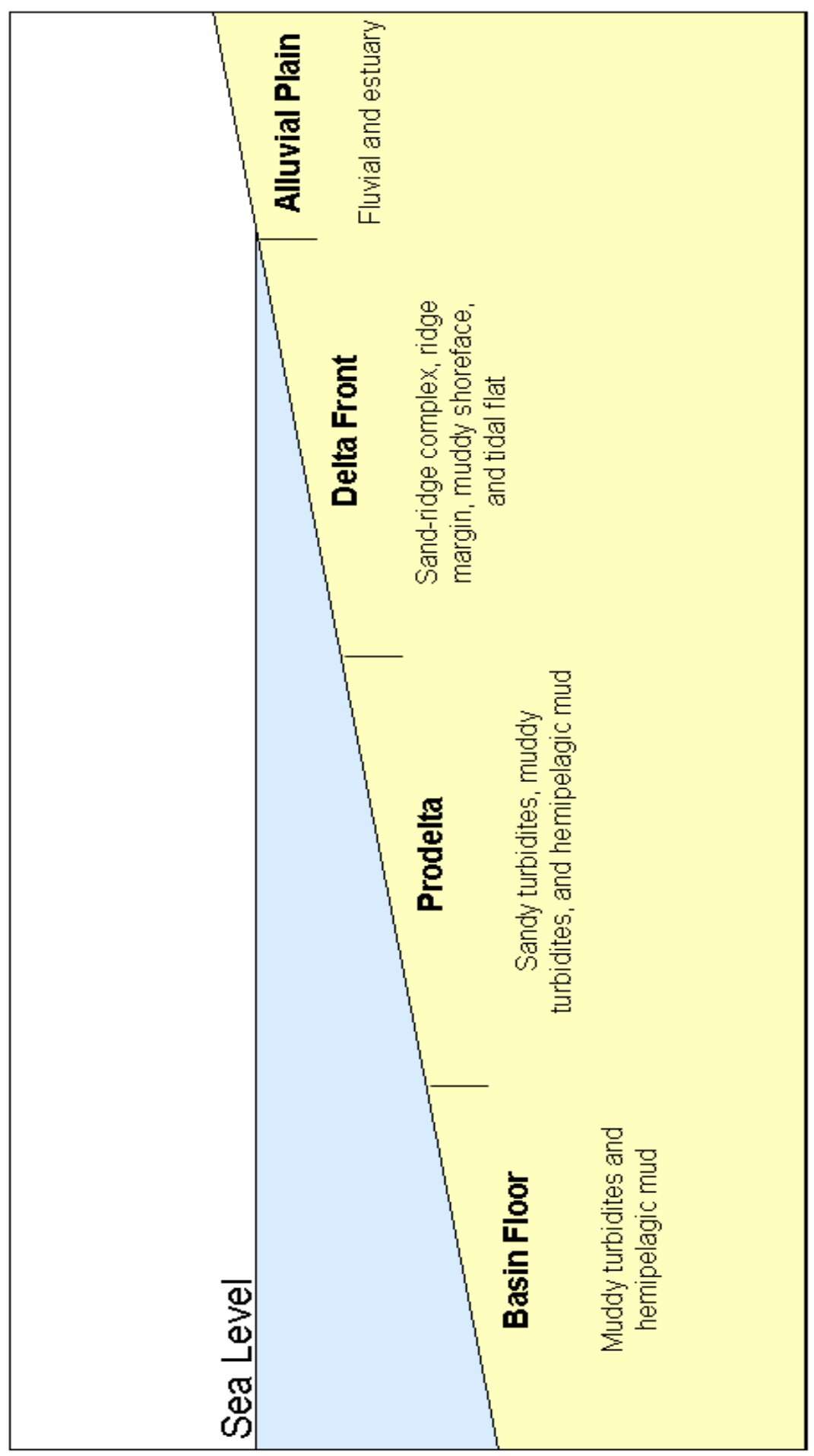

Figure 13-Foreland Ramp Setting (Based on Prothero and Schwab, 1996). 
The underlying Brallier Formation is composed of basinal deep-water deposits, and the overlying Catskill Formation is interpreted as deltaic deposits (Sevon and Woodrow, 1985; Woodrow et al., 1988). This overall shallowing-upward trend from the Brallier Formation through the Lock Haven Formation to the Catskill Formation is the result of the deposition of sediment occurring faster than creation of accommodation space (Boswell and Donaldson, 1988; Castle, 2000).

The fine-grained sandstones of the Bradford Group are the primary drilling target for gas wells in west-central Pennsylvania (Figure 14). Source beds are thought to be the Upper Devonian Burket and Middle Devonian Marcellus Formations (Laughrey et al., 2004). These black shales contain oil-prone kerogens with very mature vitrinitereflectance values ranging from $2.81-3 \%$ in the Council Run Field to the east (Laughrey et al., 2004). Upper Devonian rocks experienced burial deep enough to be exposed to temperatures between $150-200{ }^{\circ} \mathrm{C}$, and long enough to allow the cracking of the kerogens to oil and further to allow for the secondary cracking of the oil to gas within the reservoirs themselves. Structure within the Bradford Group consists of discontinuous anticlines and synclines, but trapping mechanisms are primarily stratigraphic in nature with the best reservoirs being the thicker cleaner sandstones (Boswell et al., 1996). 


\begin{tabular}{|c|c|c|}
\hline \multirow{6}{*}{ DEVONIAN } & \multirow{3}{*}{ Upper } & Hock Hayen Fm \\
\hline & & Btollier $\mathrm{Fm}_{\mathrm{m}}$ \\
\hline & & Harroll $\mathrm{Fm}_{\mathrm{m}}$ \\
\hline & \multirow[b]{2}{*}{ Middle } & Mahantango $\mathrm{Fm}$ \\
\hline & & 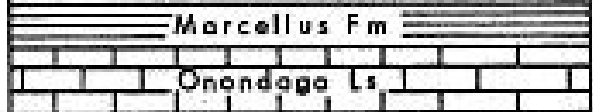 \\
\hline & Lower & $\mid I_{\text {Helderberg } G_{p} \perp}$ \\
\hline
\end{tabular}

Figure 14-Devonian Stratigraphy of Council Run Field, Centre and Clinton Counties (Laughrey et al., 2004) 


\section{DESCRIPTION AND INTERPRETATION OF THE BRADFORD ZONE}

The Bradford zone is composed of the Kane and 3rd through 1st Bradford sandstones from bottom to top. The Bradford zone averages about 350 feet thick (Figure 15) with the thickest portions being located in the northwestern part of the study area. However, the net-sandstone map (Figure 16) shows that the thickest percentage of sandstone was deposited in the central part of the study area with average values of around 50-60 feet thick. In the net-sandstone two trends are visible. One is in the strikeoriented direction and the other is in the dip-oriented direction. These trends seen in the Bradford zone as a whole exist in some of the individual drillers' sandstones but not in others. 


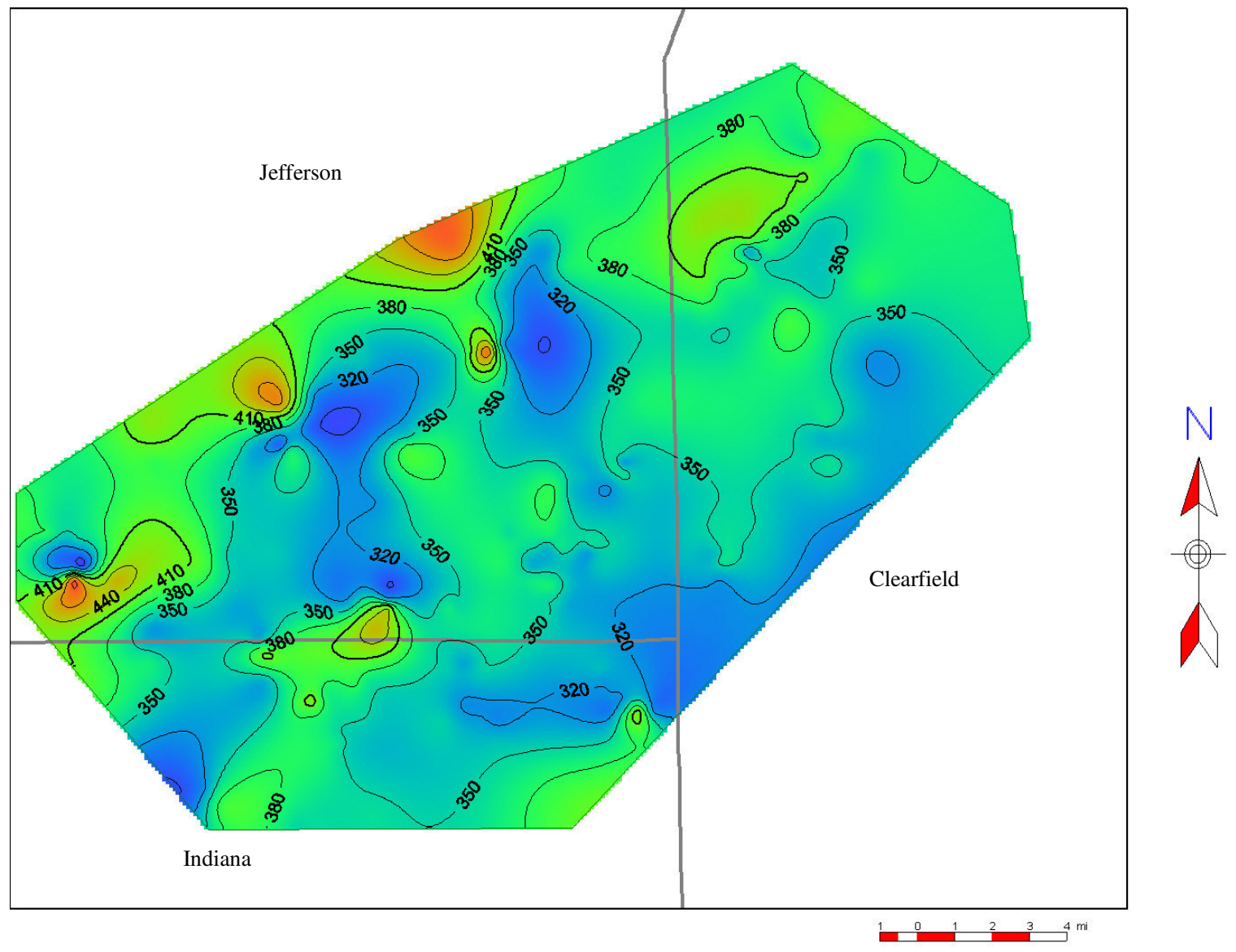

Figure 15-Isopach of Bradford Zone

Red indicates thicker section of the Bradford zone, and blue indicates a thinner section. Contour Interval $=30 \mathrm{ft}$ 


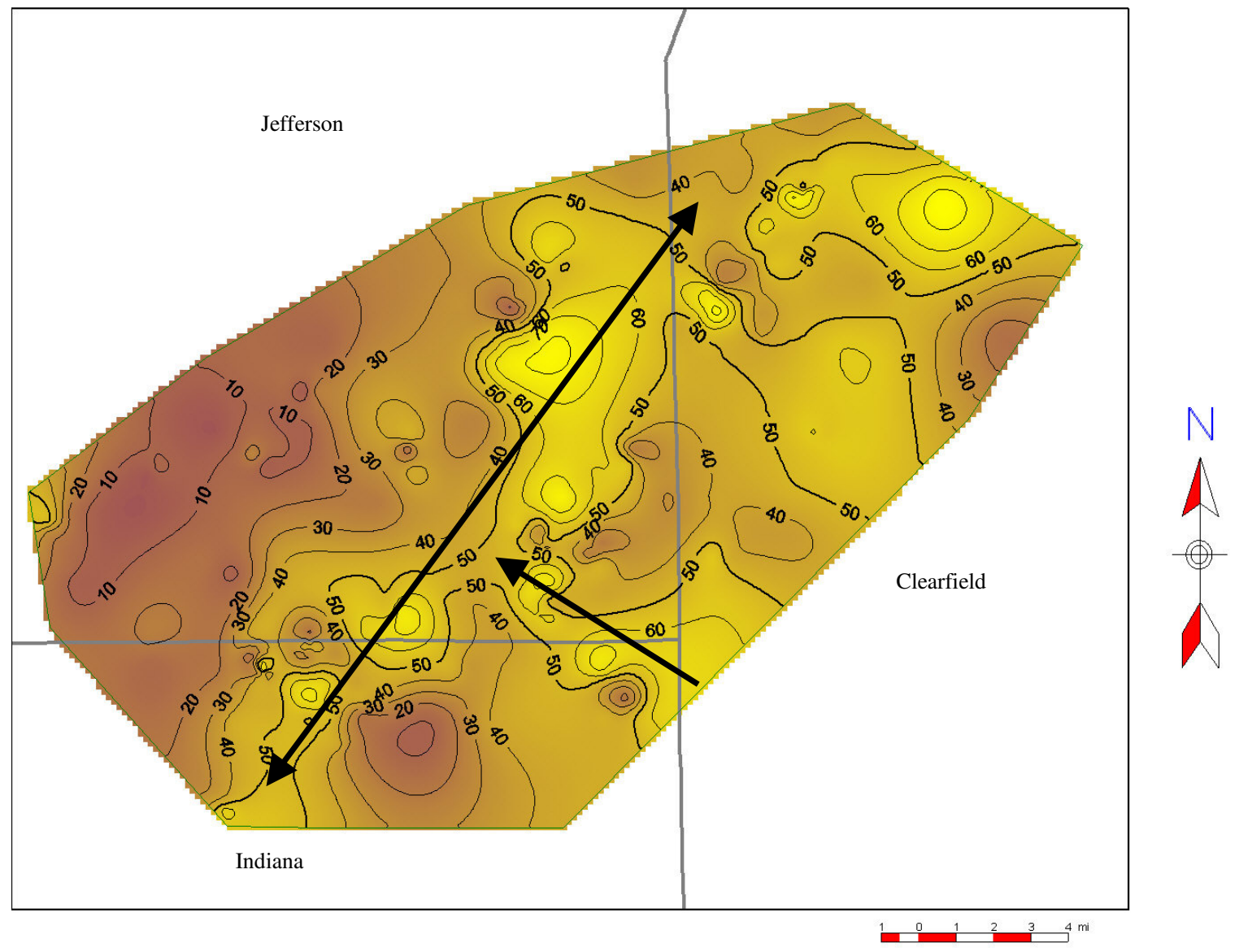

Figure 16-Bradford Zone Net-sandstone Map

Contour Interval $=10 \mathrm{ft}$ 


\section{Kane Beds}

The Kane sandstone is the basal sandstone within the Bradford zone. The Kane has just one narrow trend as seen on the net-sandstone map (Figure 17). The trend of this sandstone is in the strike direction. Net-sandstone thicknesses range from zero to 30 feet but average about 15 feet thick along the trend axis. However, to the west and east the net-sandstone values drop to zero where the Kane passes laterally to shales overlying the Brallier Formation. This lenticular shape can also be observed in cross section (Figures 18 and 19). 


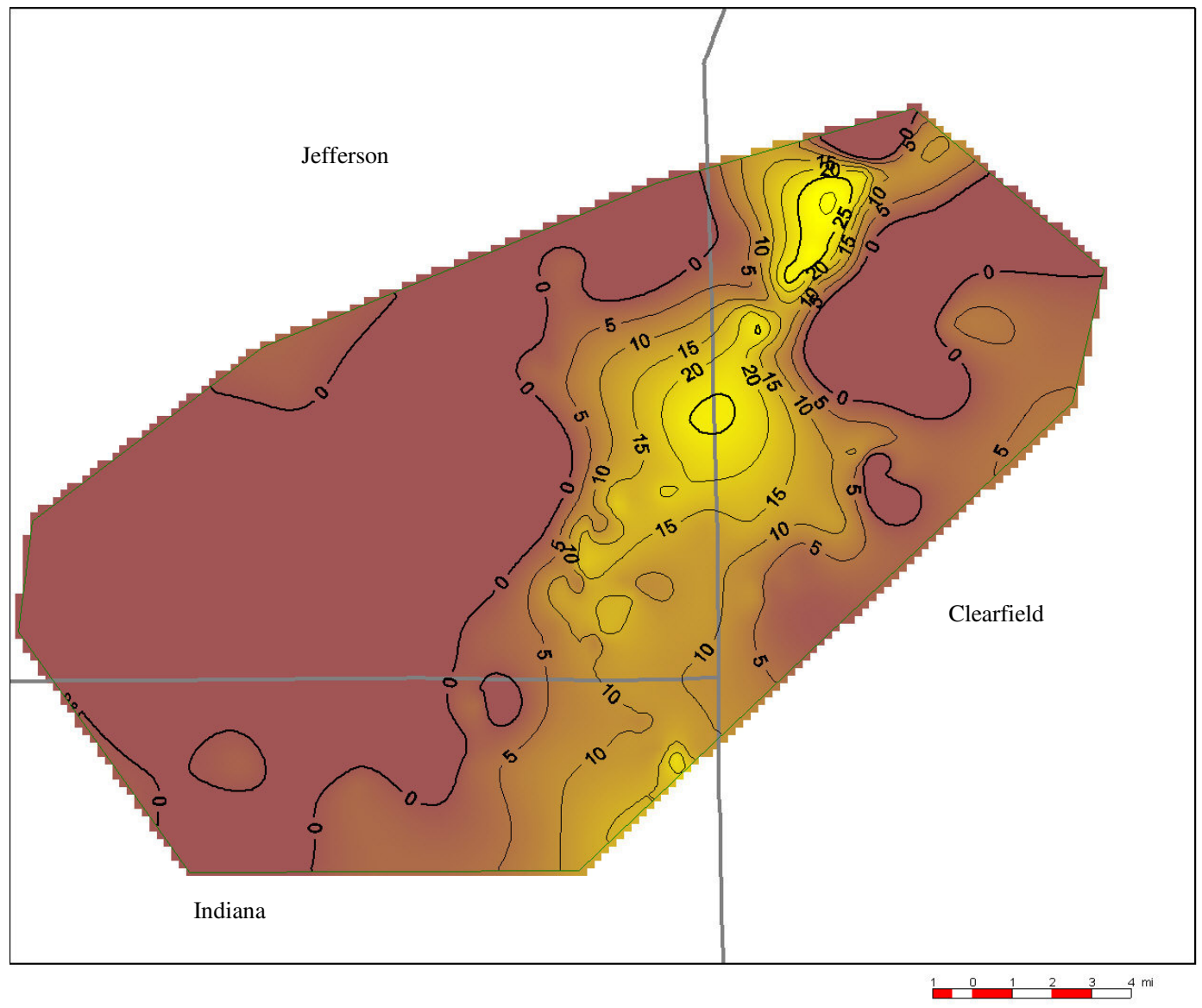

$N$
$\Lambda$

Figure 17-Kane Net-sandstone Map

Contour Interval $=5 f t$ 


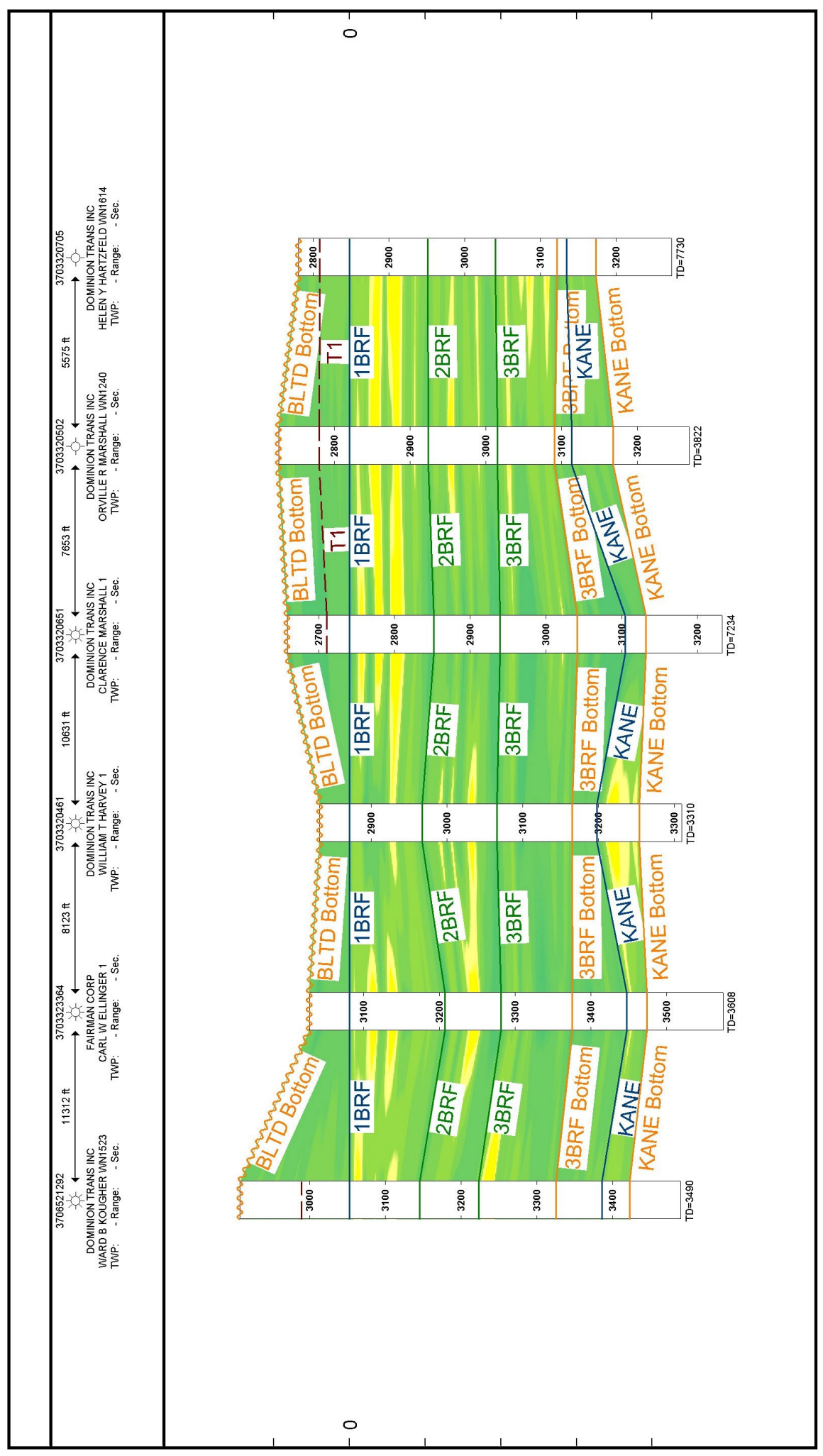

Figure 18-A-A'Dubois Dip Trending Bradford Zone Cross Section

See figure 12 for location of the cross section. 


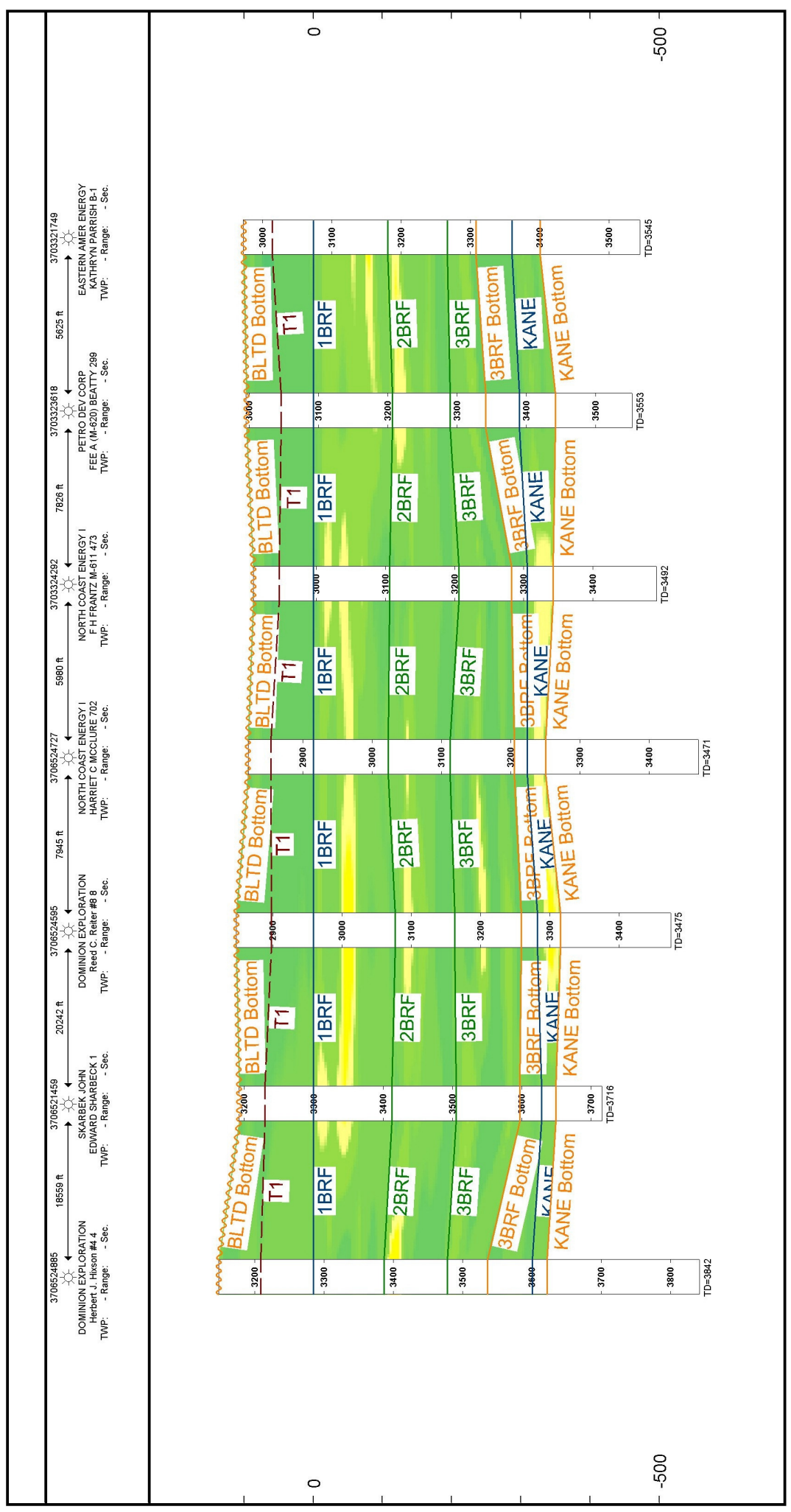

Figure 19-B-B' McGees Mill Dip Trending Bradford Zone Cross Section

See figure 12 for location of cross section. 
Hussing (1994) interpreted the Kane to be a type SD2 sandstone (Boswell and Jewell, 1988), in the Cush Cushion field, 15-20 miles to the southeast of the Greater Punxsutawney area. Boswell and Jewell (1988) defined SD2 sandstones as those that show both strike and dip trends and were deposited in near shore environments. There the Kane shows both strike and dip trends which are typical of distributary mouth bar and lower fluvial-deltaic plain deposits (Boswell, 1985). In the study area I interpret the Kane bed to be representative of deep-water mudflow and turbidite deposits. There is one main lobe of sediment accumulation in the study area (Figure 20). The lobe is up to 80 feet thick with as much as 25 feet of sandstone, as is seen by the net-sandstone values in Figure 18. To the east of this sandy lobe is a shale thick that is interpreted as being representative of a slump or semi-consolidated mud flow. The thicker values seen in Figure 20 entering from the southeast are interpreted as a feeder channel through which sediment from turbidity currents was transported into the study area. To the west of these deposits is the basin floor where the basinal shales representative of the Brallier Formation were deposited. The occurrence of these turbidites and gravity flows in the study area was the result of the onset of a forced regression that resulted in the build up and increasing instability of sediment along the delta front as accommodation space decreased (Catuneanu, 2006). The occurrence of storms within the basin would have lowered wave base, and caused the unstable accumulations of sediment to cascade down the delta front and accumulate on the underlying deep-water shales of the Brallier formation (Harper and Laughery, 1987). Therefore, the base of the Kane sandstone within the study area represents the basal surface of forced regression and the onset of the 
falling stage systems tract (FSST) (Catuneanu, 2006) that caused sediment to accumulate within the study area.

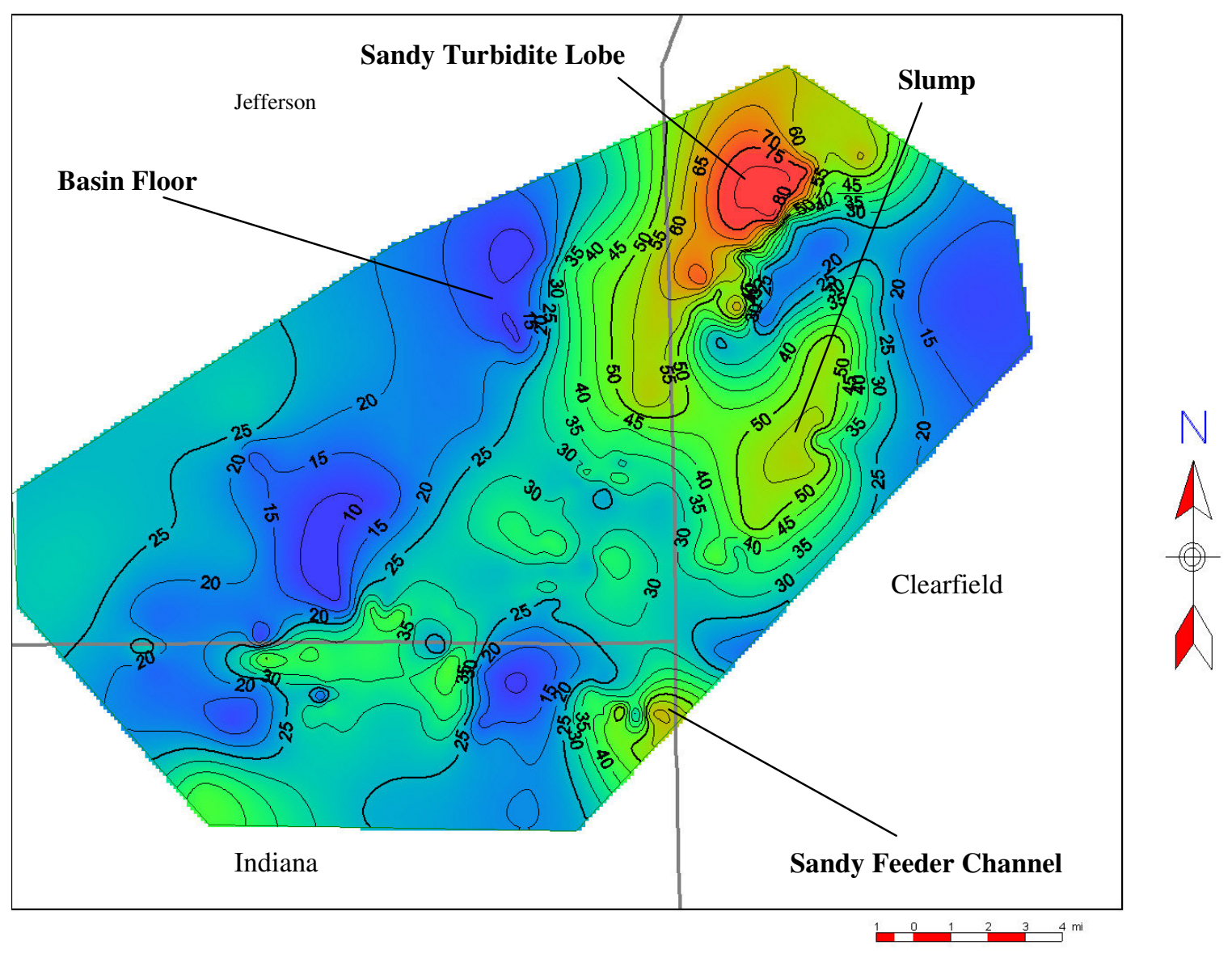

Figure 20-Kane Isopach Map

Contour Interval $=5 f t$ 


\section{Third Bradford Beds}

Above the Kane sandstone is the Third Bradford sandstone. The base of the Third Bradford is most easily observed overlying the Kane within the south Punxsutawney cross section (D-D' Figure 21) near well 37-063-21568, but where there is no basal sandstone a regionally correlative shale is used. The basal sandstone unit within the Third Bradford is a silty sandstone on the gamma-ray log, and is relatively continuous across the study area. The upper part of the Third Bradford horizon contains a lower-API unit sandstone that is easily observed within the northern Punxsutawney cross section (CC' Figure 22). In map view the Third Bradford is seen to have net-sandstone values that average around 15-20 feet thick and two distinct trend directions; a trend in the east and a second through the middle of the study area (Figure 23). These trends are parallel to the dip (west-northwest), and the strike directions (east-northeast to west-southwest) of the Appalachian foreland ramp (Boswell and Jewell, 1988). In cross section the Third Bradford is composed of multiple sandstone beds stacked on top of one another and separated by shale breaks. The thickest sandstone units are present at the top of the Third Bradford (Figures 18, 19, 21, and 22). Figure 22 also show the Third Bradford stepping seaward or offlapping over time with the majority of sandstone being located in the northern and southern ends of the study area (Figures 23 and 24). 


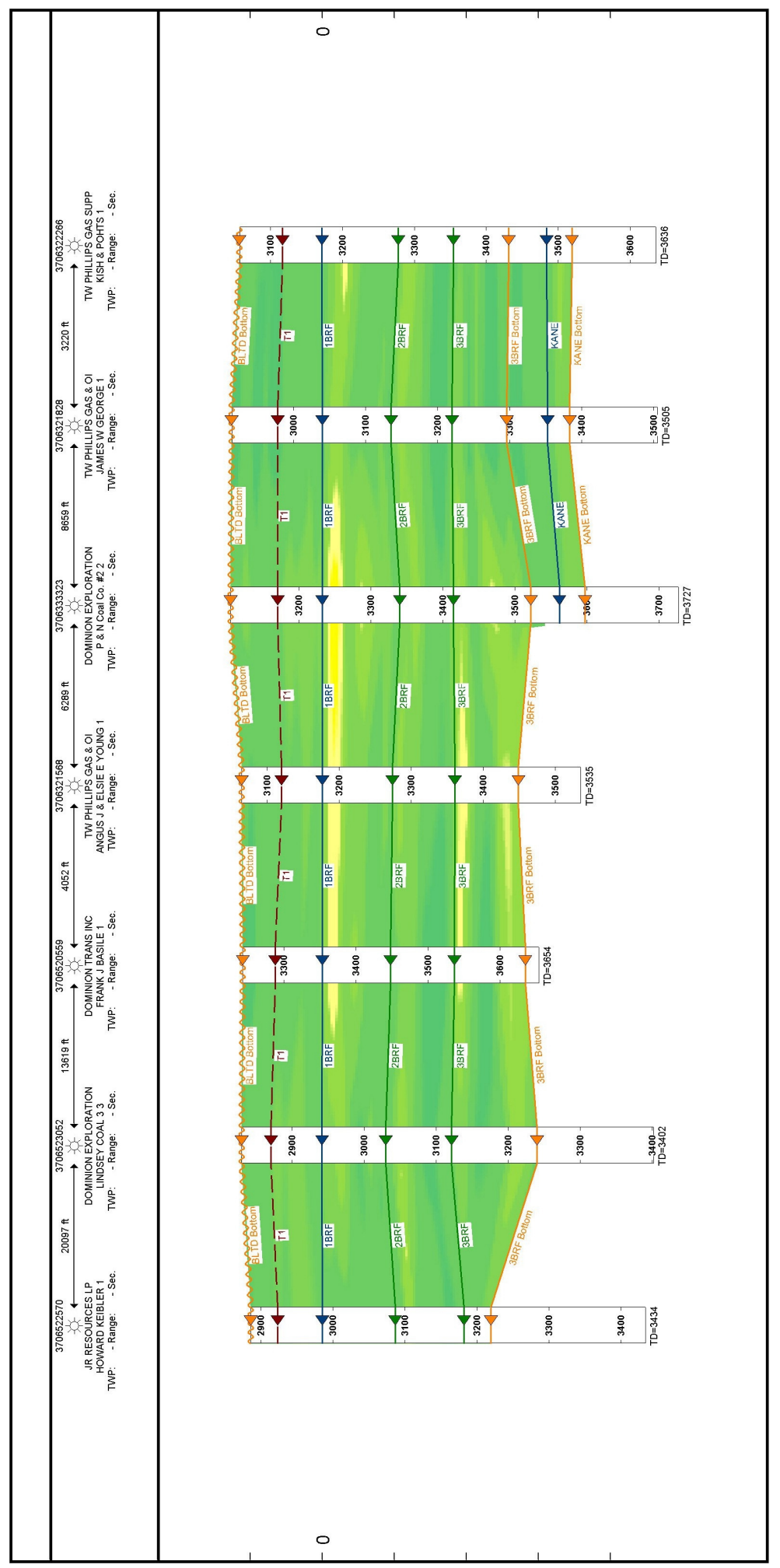

Figure 21-D-D' Southern Punxsutawney Dip Trending Bradford Zone Cross Section

See Figure 12 for the location of the cross section. 


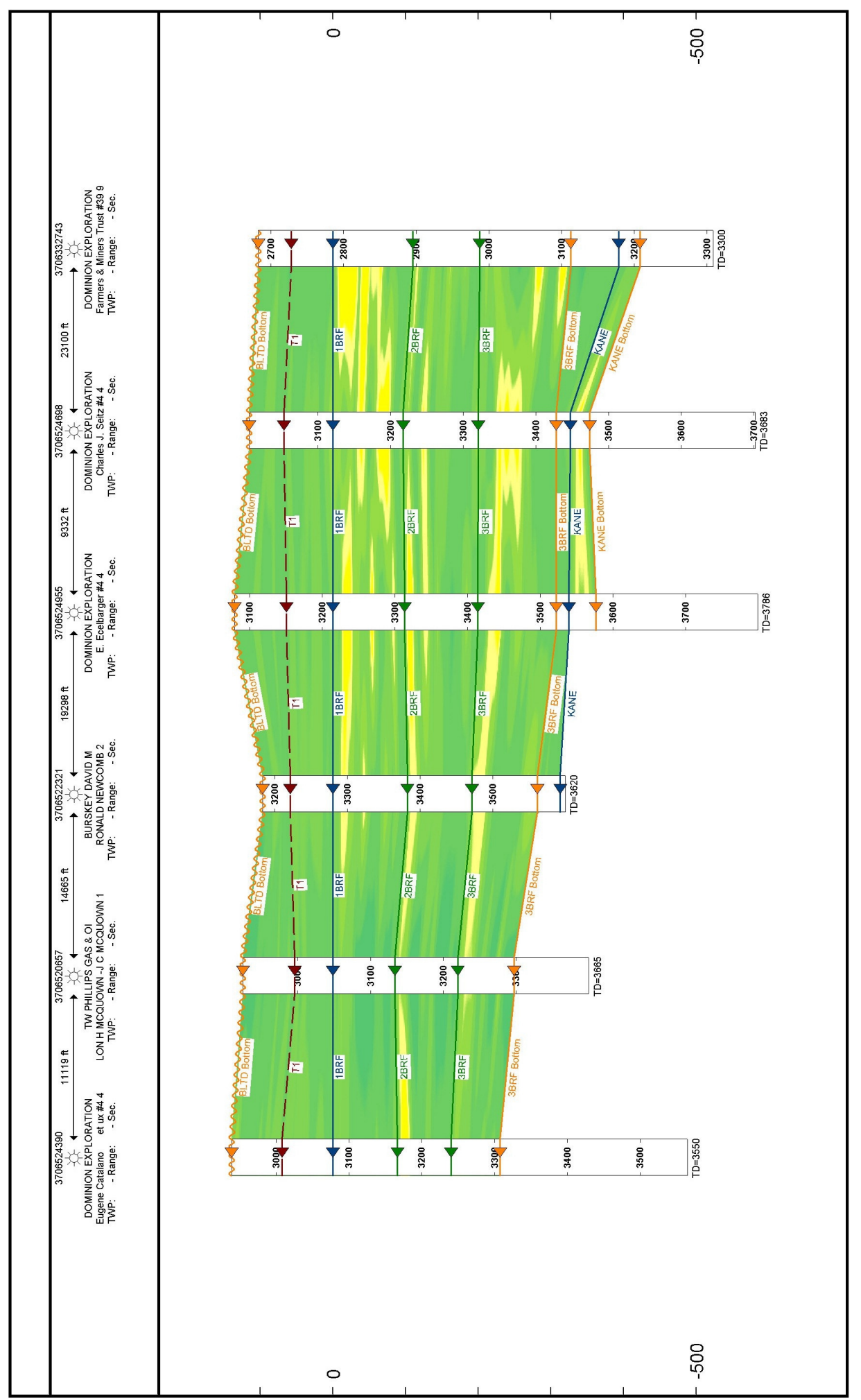

Figure 22-C-C' Northern Punxsutawney Dip Trending Bradford Zone Cross Section

See Figure 12 for the location of the cross section. 


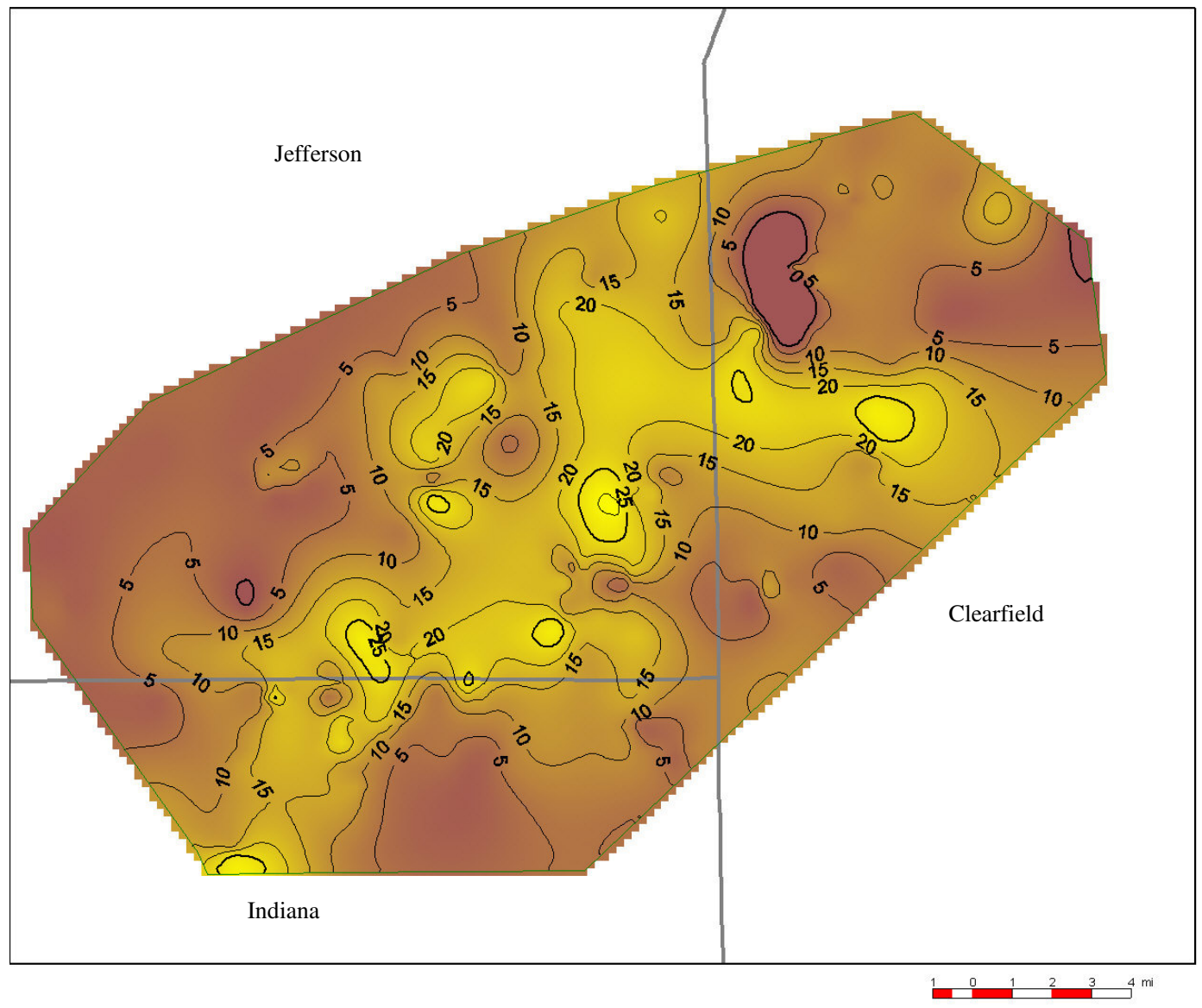

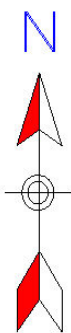

Figure 23-Third Bradford Net-sandstone Map

Contour Interval $=5 f t$ 


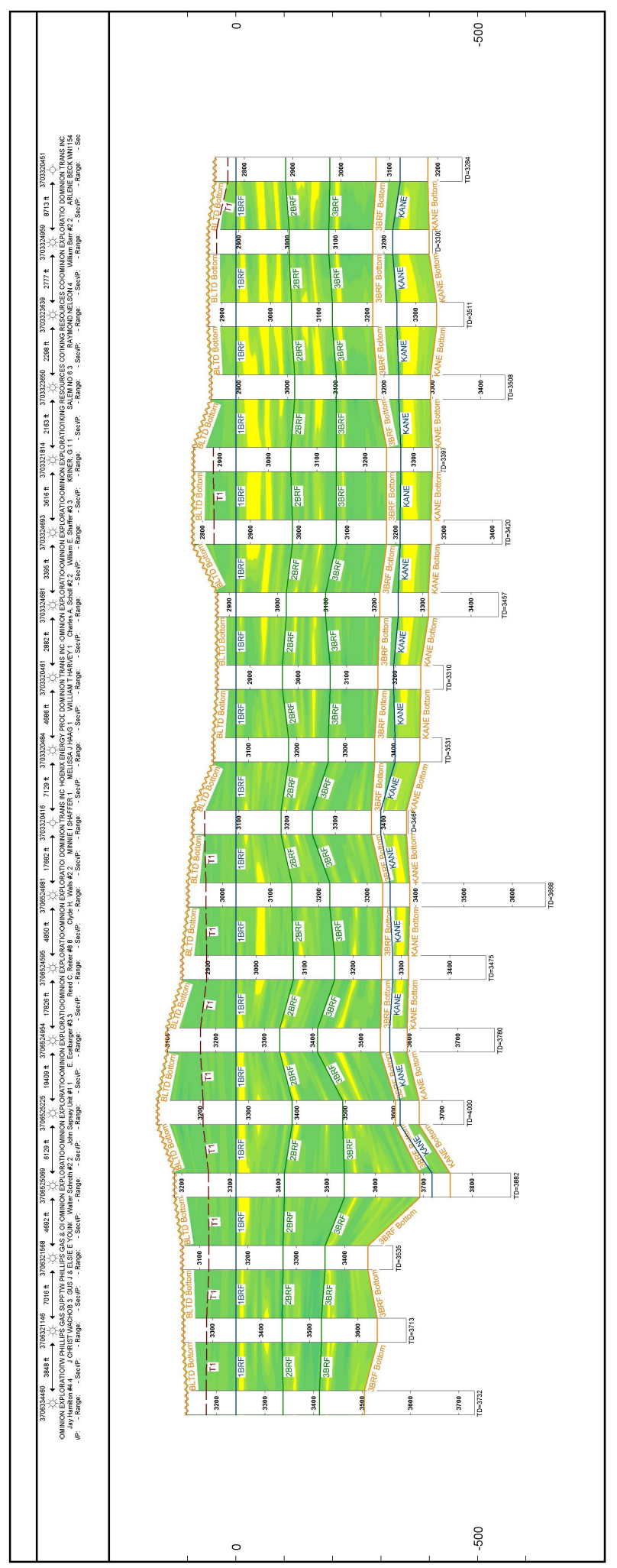

Figure 24-E-E' Strike Trending Bradford Zone Cross Section

See Figure 12 for the location of the cross section. 
The Third Bradford is a continuation of the falling stage systems tract, during which sediment was fed into the study area via two separate feeder channels (Figure 25). Through the eastern most feeder channel both sand and mud were transported into the study area. However, the southeastern feeder channel transported primarily mud into the study area. The sediment being transported into the study area during this time was composed primarily of mud that accumulated in two major lobes at the toe of the slope. The strike trending sandstones observed in Figure 23 were deposited as the result of turbidites that cut across the muddy fan and then turned to move along the toe of the fan when they reached the base of the slope and lost energy. However, these turbidites compose only a small percentage of the sediment being transported into the study area during this time. The turbidites of the Third Bradford are of the same facies as the Kane, but are sandier, coarser, and they increase in thickness near the top of the Third Bradford. This is evidence to the further progradation of sediment basinward as sea level continued to fall during this time. 


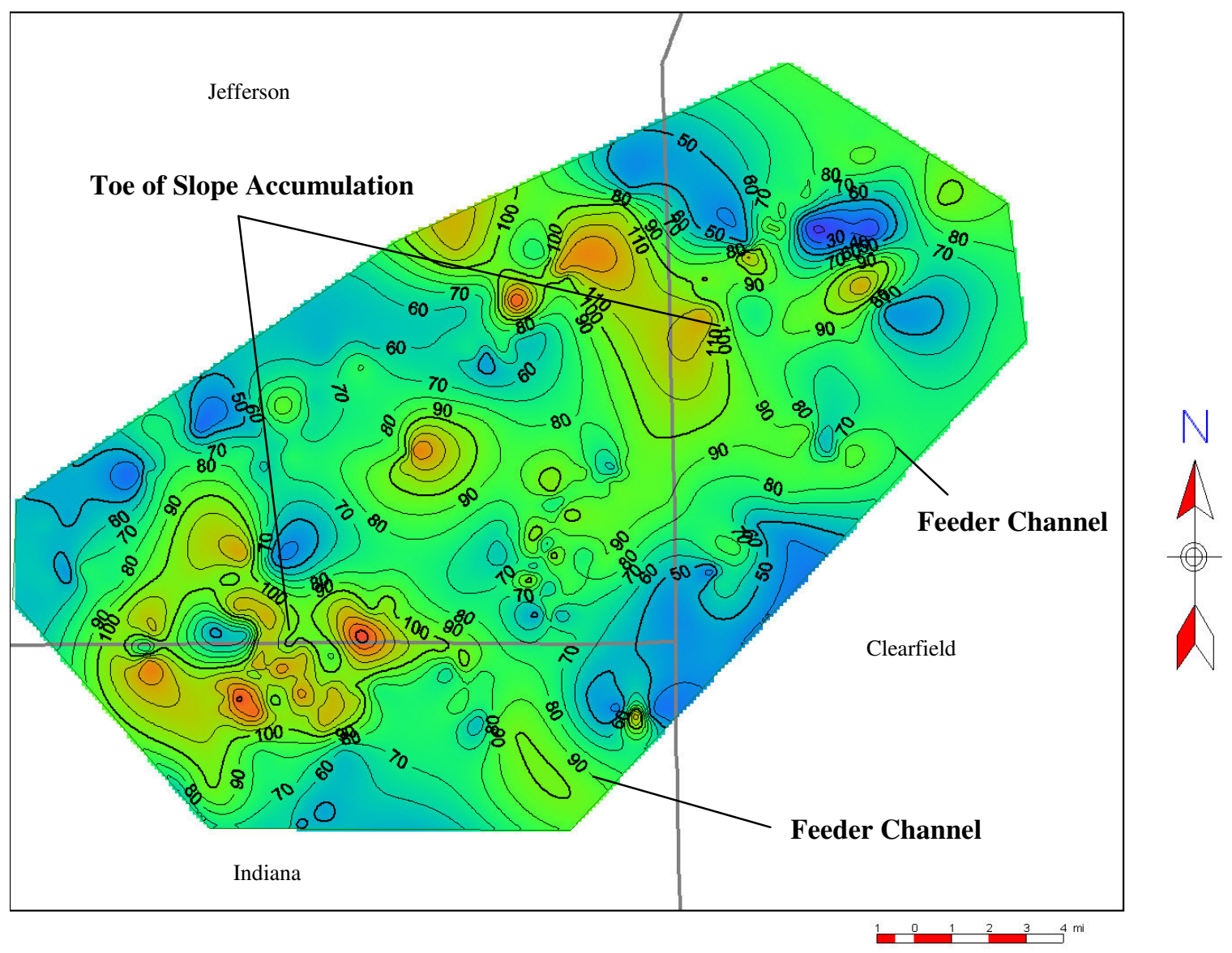

Figure 25-Third Bradford Isopach Map

Contour Interval $=10 f t$ 


\section{Second Bradford Beds}

The Second Bradford net-sandstone map (Figure 26) does not readily display the definite trends seen in the Third Bradford. It is much more dispersed across the Greater Punxsutawney Area, averaging about 10 to 15 feet thick. This is approximately 10 feet thinner than the net-sandstone values of the Kane and Third Bradford sandstones. The McGees Mill and Northern Punxsutawney cross sections (Figures $19 \& 22$ ) show that the thickest sections of sandstone within the Second Bradford horizon are found higher in the stratigraphic section and in the southern part of the field (Figure 24). However, in the northern part of the field, sandstone is found in the middle of the Second Bradford interval. 


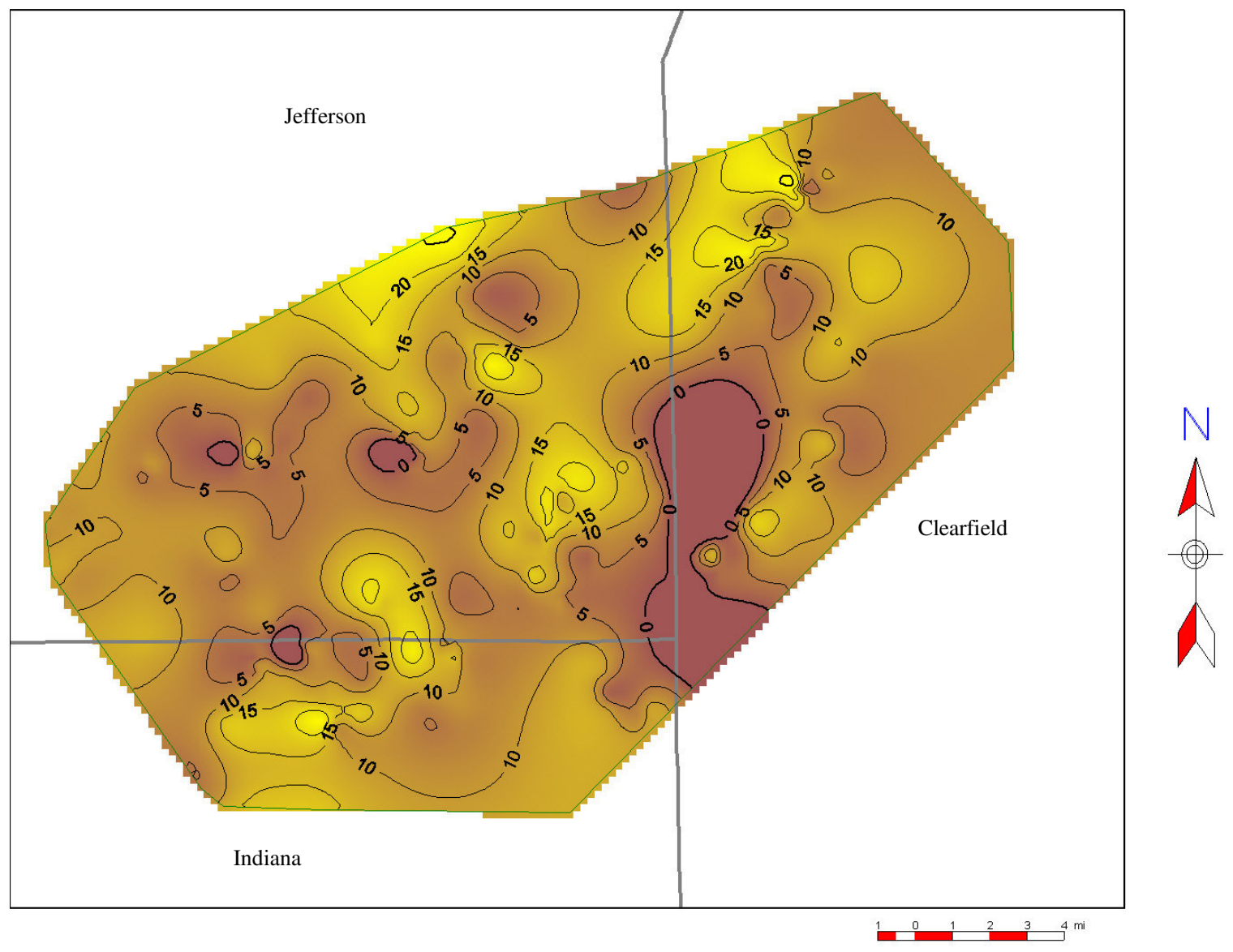

Figure 26-Second Bradford Net-sandstone Map

Contour Interval $=5 f t$ 
The distribution of these sandstones shows that much of the sediment deposited during Second Bradford time consisted primarily of mud which filled two separate feeder channels (Figure 27). This distribution means that at this time coarser sediment was either carried farther out into the basin via these feeder channels or was trapped along fluvial and nearshore environments (Catuneanu, 2006), therefore reducing the sand thickness within the study area. I interpret the deposition of the Second Bradford to be representative of the early lowstand systems tract. It was during this time that eustatic sea level stopped falling and slowly began to rise, but was outpaced by the sedimentation rate. This resulted in the normal regression of sea level within the study area. The occurrence of more sandstone within the uppermost section (coarsening-upward sequence) of the Second Bradford interval is evidence of this. The trapping of coarse sediment near the shore permitted only finer-grained sediments to extend farther offshore, and resulted in the deposition of primarily mud within the study area during this time. 


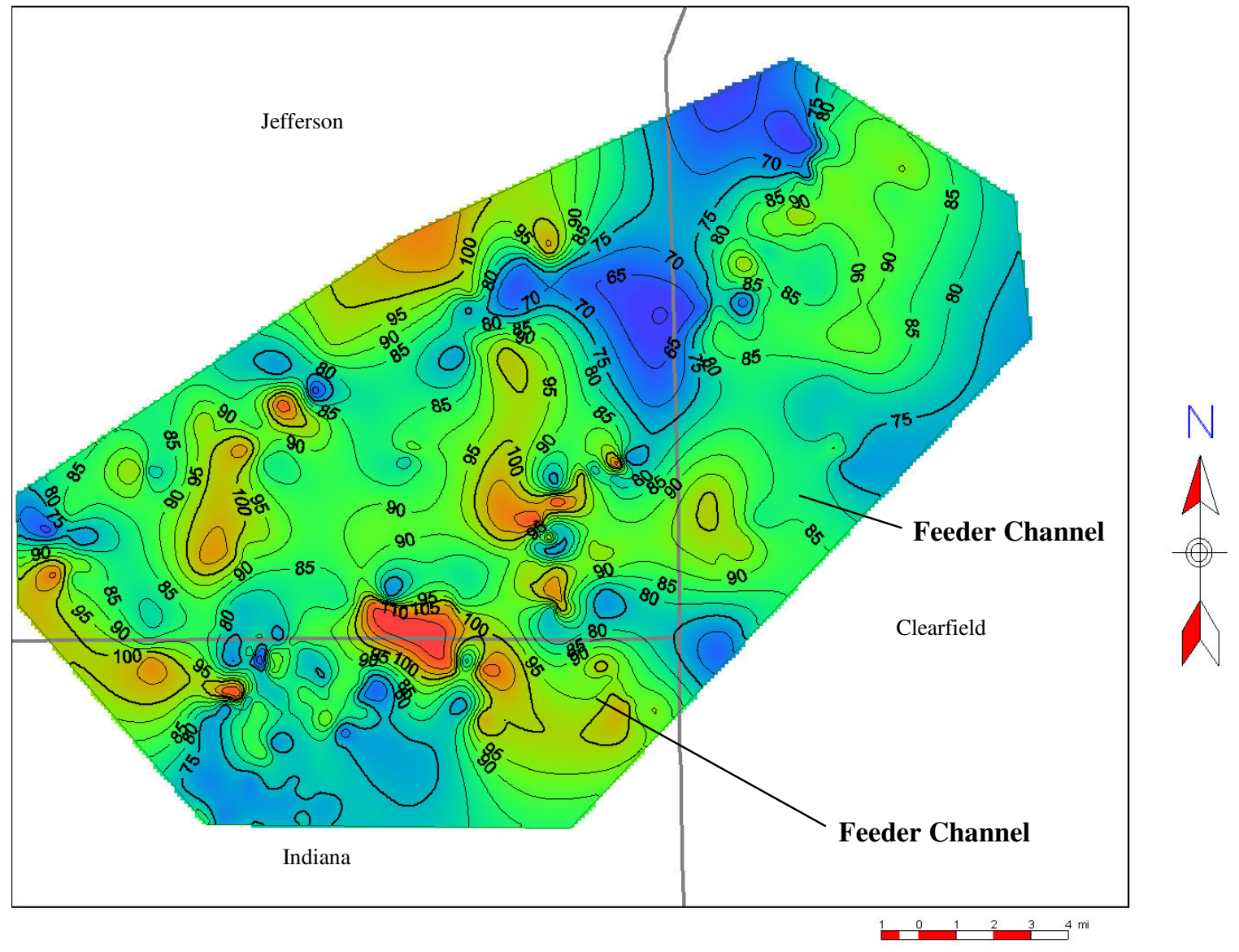

Figure 27-Second Bradford Isopach Map

Contour Interval $=5 f t$ 


\section{First Bradford Beds}

The First Bradford is the uppermost sandstone of the Bradford zone and lies directly above the Second Bradford. Within the Greater Punxsutawney area, the netsandstone map shows that the First Bradford sandstone is widespread and is present in most of the eastern part of the study area (Figures 28). Typical values for the First Bradford net-sandstone map are around 25 to 30 feet thick, but are as thick as 45 feet. These are the thickest net-sandstone values seen within the Bradford zone. The occurrence of sandstone primarily within the eastern part of the study area is also seen in cross section (Figures 20 and 24) with little or no sandstone being found to the west. 


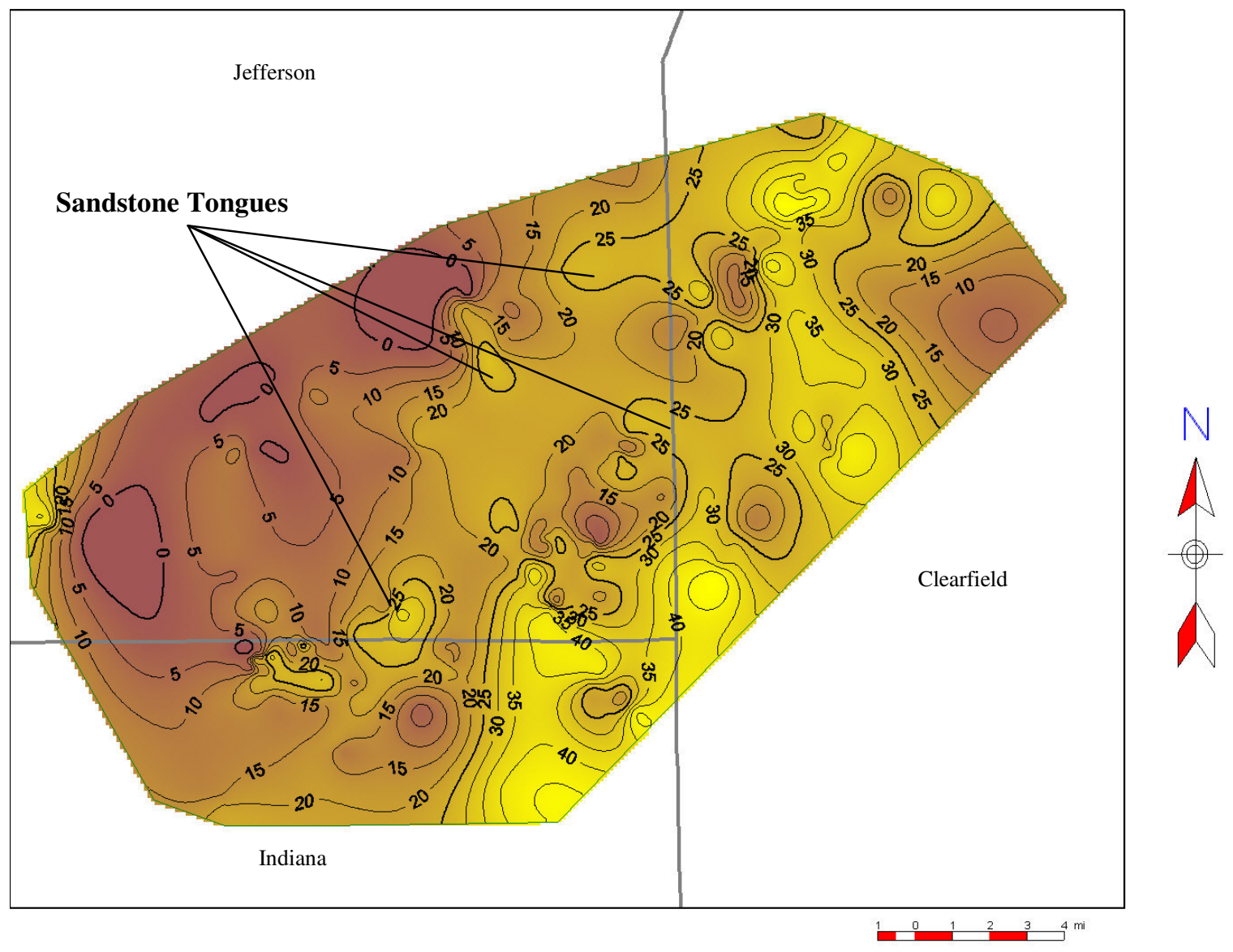

Figure 28-First Bradford Net-sandstone Map

Contour Interval $=5 f t$ 
The study of the First Bradford in west-central Pennsylvania by Murin (1988) interpreted the First Bradford drillers' sandstone in the Greater Punxsutawney area from a full-bore coring of well 37-033-21356 and e-log mapping (Figure 29). Murin (1988) concluded that the First Bradford is composed of longshore bars of a delta front reworked by storm waves. The sedimentary structures of sandstones in the First Bradford include high and low angle cross bedding, massive bedding, load structures, and burrows. Porosity values within the First Bradford are around 8\%, and permeabilties around 0.01md in unfractured core plugs (Murin, 1988). These sandstones are separated by thin dark organic-rich shale beds interpreted as anoxic lagoonal deposits. Sedimentary structures within these shales include lenticular bedding, wavy and parallel laminae, and horizontal bedding. The core of the First Bradford within this well also allowed for the description of a basal shell bed containing bryozoans and brachiopods representative of a lag deposit. 


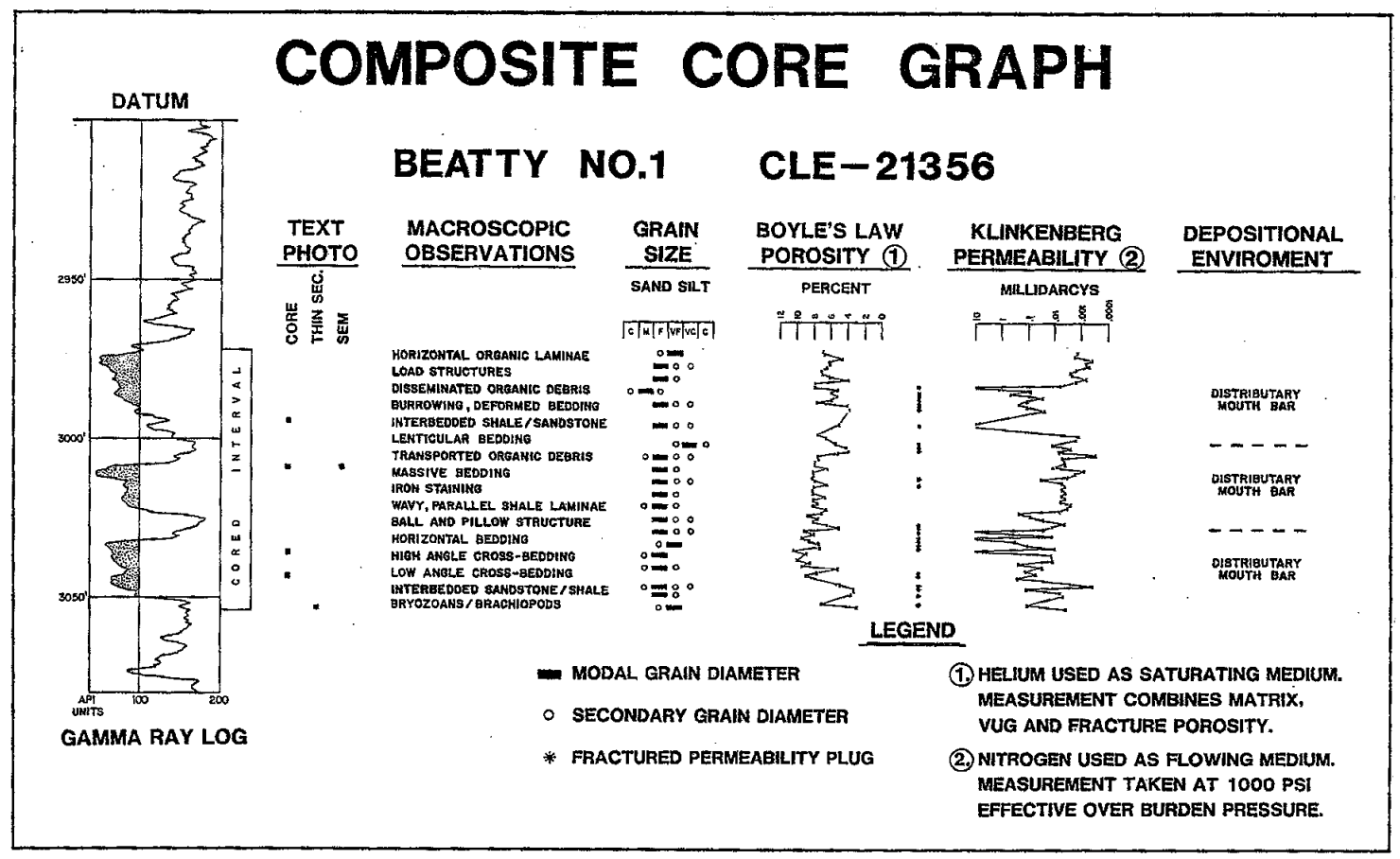

Figure 29-Composite Core Graph of First Bradford (Murin, 1988) 
I interpret the First Bradford as being deposited as longshore sandbars of the delta front (Figure 30) during the latest part of the lowstand systems tract. This was a continuation of the normal regression that began during Second Bradford time. During First Bradford time the shoreline had moved into the eastern part of the study area due to the large influx of sediment, and the sea floor was now shallow enough to be affected by storm wave base. The continuing normal regression of sea level allowed large volumes of sand (up to $45 \mathrm{ft}$. thick) to accumulate along the delta front where storms reworked them into the longshore bars. Sandstone tongues seen in the western part of the study area are interpreted as possible offshore sand ridges, and sandstone to the east of the study area are primarily lagoonal deposits located behind the sand bars of the delta front. Basinal shales and previously observed turbidite lobes are now located to the west beyond the study area. 


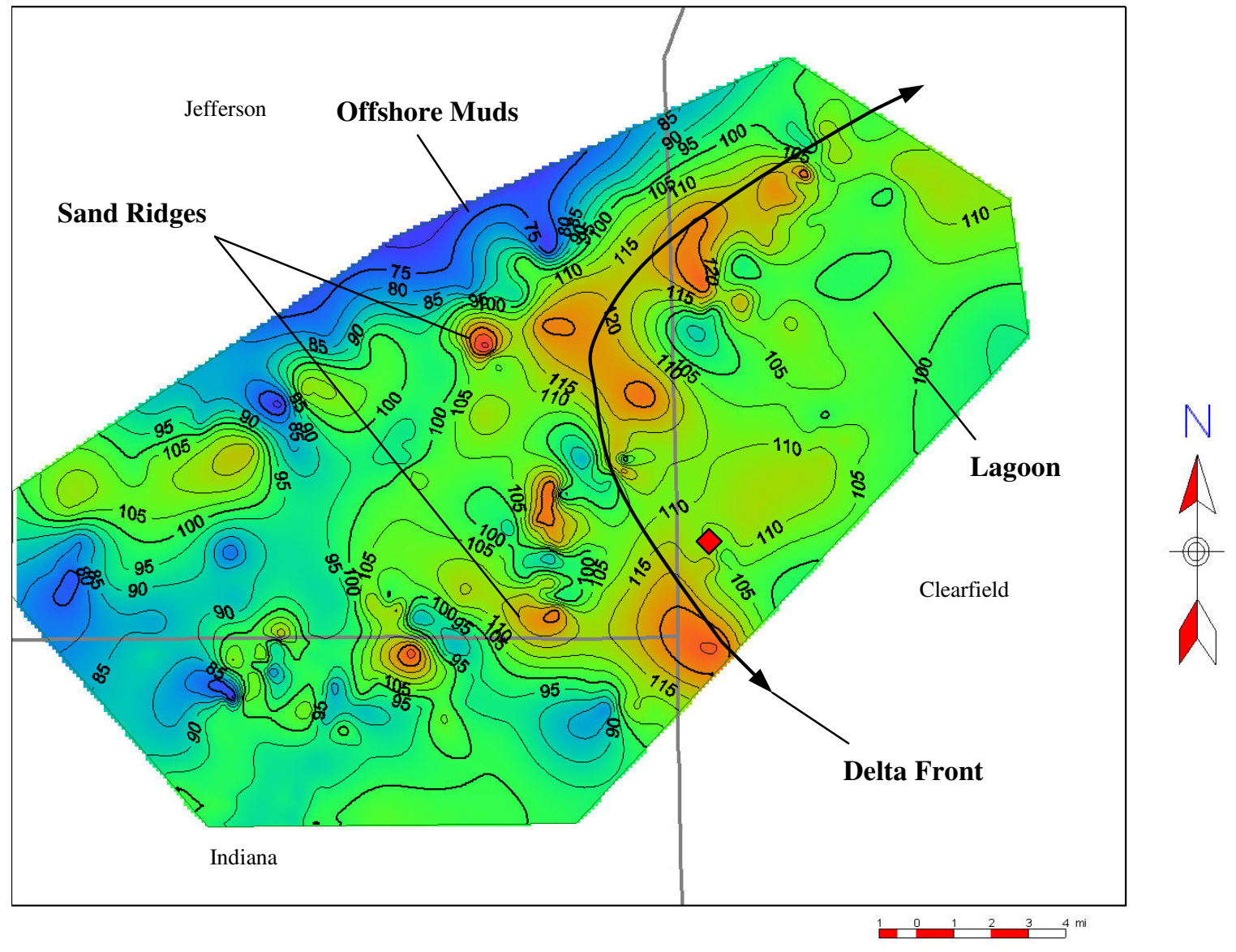

Figure 30_First Bradford Isopach Map

\Cored Well \# 37-033-21356 (Murin, 1988)

Contour Interval $=5 f t$ 


\section{T1 Shale Beds}

The top of the First Bradford is marked by a distinct change from sandstone to shale, which for purposes of this study is called the T1 (informal industry term) shale beds, and indicates a rapid increase in relative sea level. The surface at the top of the First Bradford marks the point of maximum regression of sea level within the study area and the point at which relative sea-level rise began to outpace the rate of sedimentation. This caused coarser sediments to be trapped in coastal and fluvial environments as the transgressive systems tract began. Within the study area the transgressive systems tract is composed primarily of shale that was deposited on the basin floor (Figure 13).

The $\mathrm{T} 1$ beds contain a radioactive marker across much of the study area (Figures $6 \& 11)$. This radioactive bed is interpreted as a condensed section and marks the highest position of sea level or the maximum flooding surface within the Bradford zone.

Therefore, the $\mathrm{T} 1$ beds represent the end of the transgressive systems tract, and the onset of the highstand systems tract (HST). Directly above the T1 are the shales of the HST of the Bradford zone. The HST of the Bradford zone varies from a typical HST in that the normal regression of sea level and progradation of sediment back into the study area is not seen. However, in the northeastern part of the study area, the cross section shows that the overlying Balltown D of the Balltown zone has scoured into the shales of the Bradford zone (Figure 24). The T1 isopach map (Figure 31) also shows evidence of this erosion where in the eastern part of the study area the $\mathrm{T} 1$ is markedly thinner in areas interpreted as incised channels based on the presence of the basal sandstone of the Balltown D and absence of the uppermost T1 shale beds. Therefore, the top of the T1 is 
interpreted as an unconformity. This unconformity marks the top of the Bradford zone, the end of the highstand systems tract, and the end of the first stratigraphic sequence.

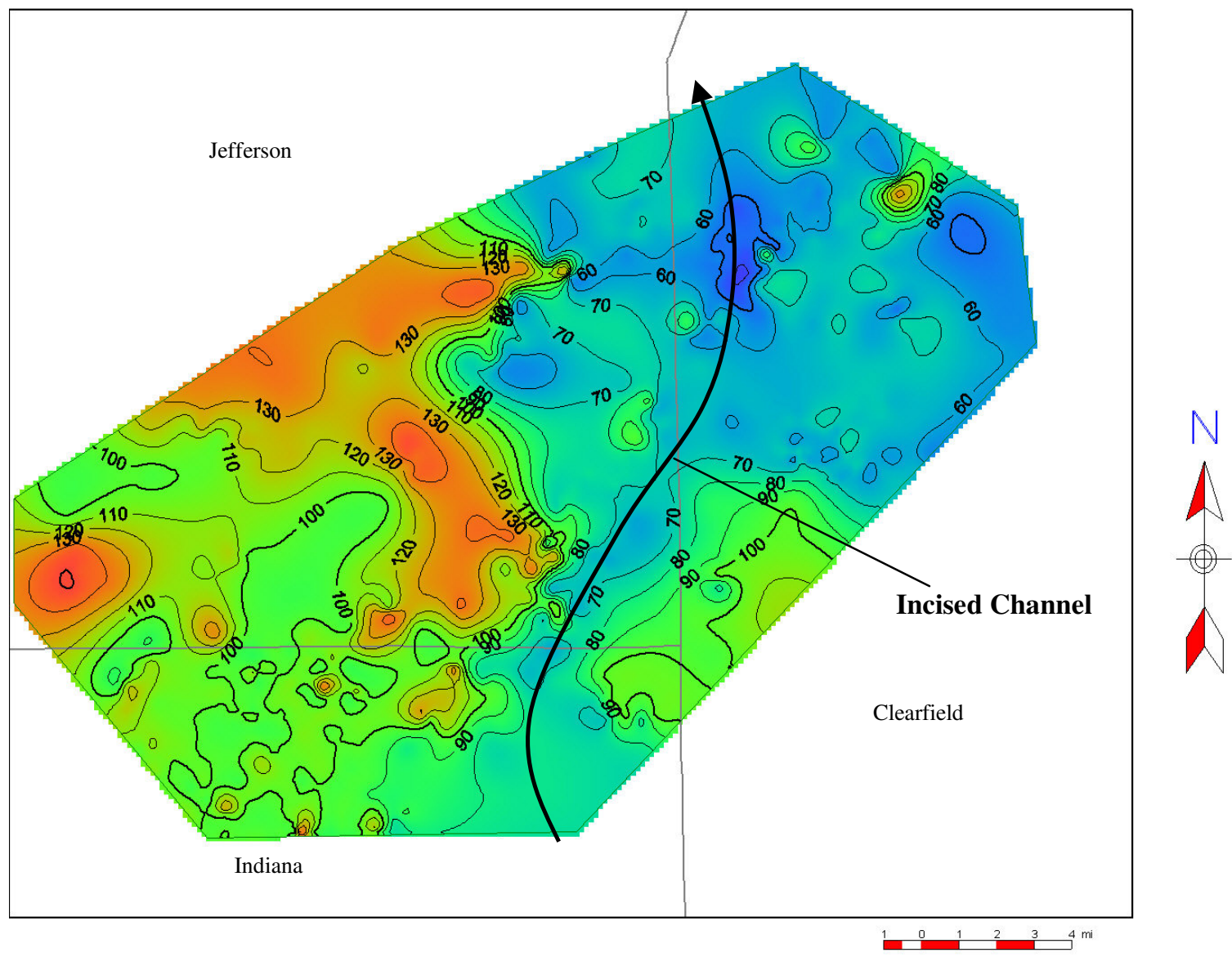

Figure 31-Isopach Map of the T1 Shale

Contour Interval $=10 \mathrm{ft}$ 


\section{DESCRIPTION AND INTERPRETATION OF THE BALLTOWN ZONE}

The Balltown zone is composed of the Balltown D through A and Speechley beds (from bottom to top). The Balltown zone averages about 400 feet thick across much of the study area with a thickness of up to 450 feet (Figure 32). Net-sandstone values of the Balltown zone average about 40 feet thick with maximum values of 80 feet thick (Figure 33). The thickest sandstone is located in the west-central and eastern parts of the study area with thinner sandstone elsewhere. The thickest net-sandstone packages show two NE-SW parallel trends.

Sandstone and shale of the Balltown zone are stratigraphically equivalent to the upper Lock Haven Formation and have been interpreted in outcrop to be representative of shoreline, deltaic, estuarine, and tidal flat environments (Walker, 1971; Walker and Harms, 1971; Glaeser, 1974; Slingerland and Loule, 1988; Warne and McGhee, 1991). Cotter and Driese (1998) identified incised channels, estuarine fill, fluvial channels, exposed mud flats, and shallow-marine deposits in outcrop approximately 80 miles due east of the study area near Selinsgrove, PA in Snyder County (Figure 1). 


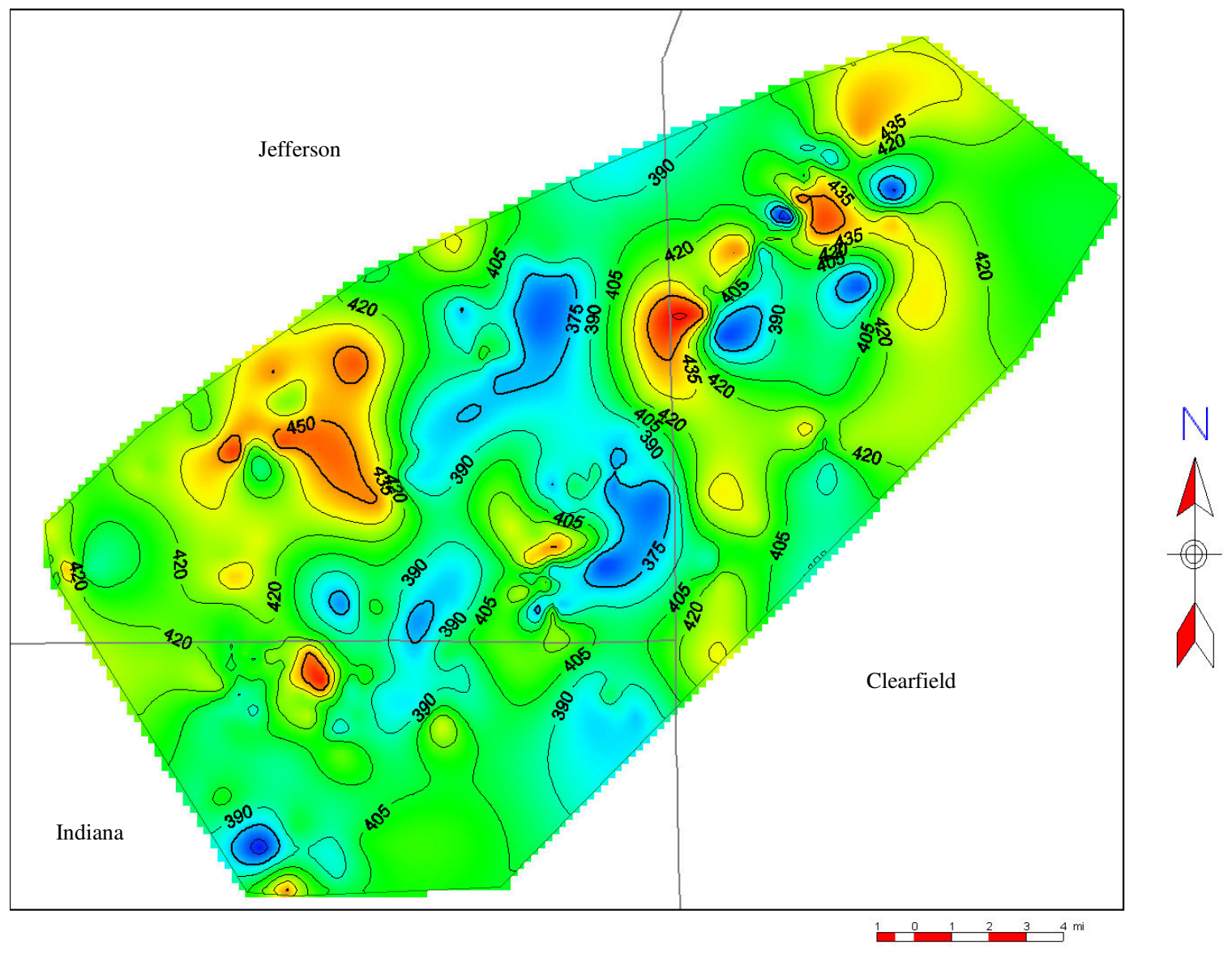

Figure 32-Isopach of Balltown Zone

Red indicates thicker section of the Balltown zone, and blue indicates a thinner section. Contour Interval $=15 \mathrm{ft}$ 

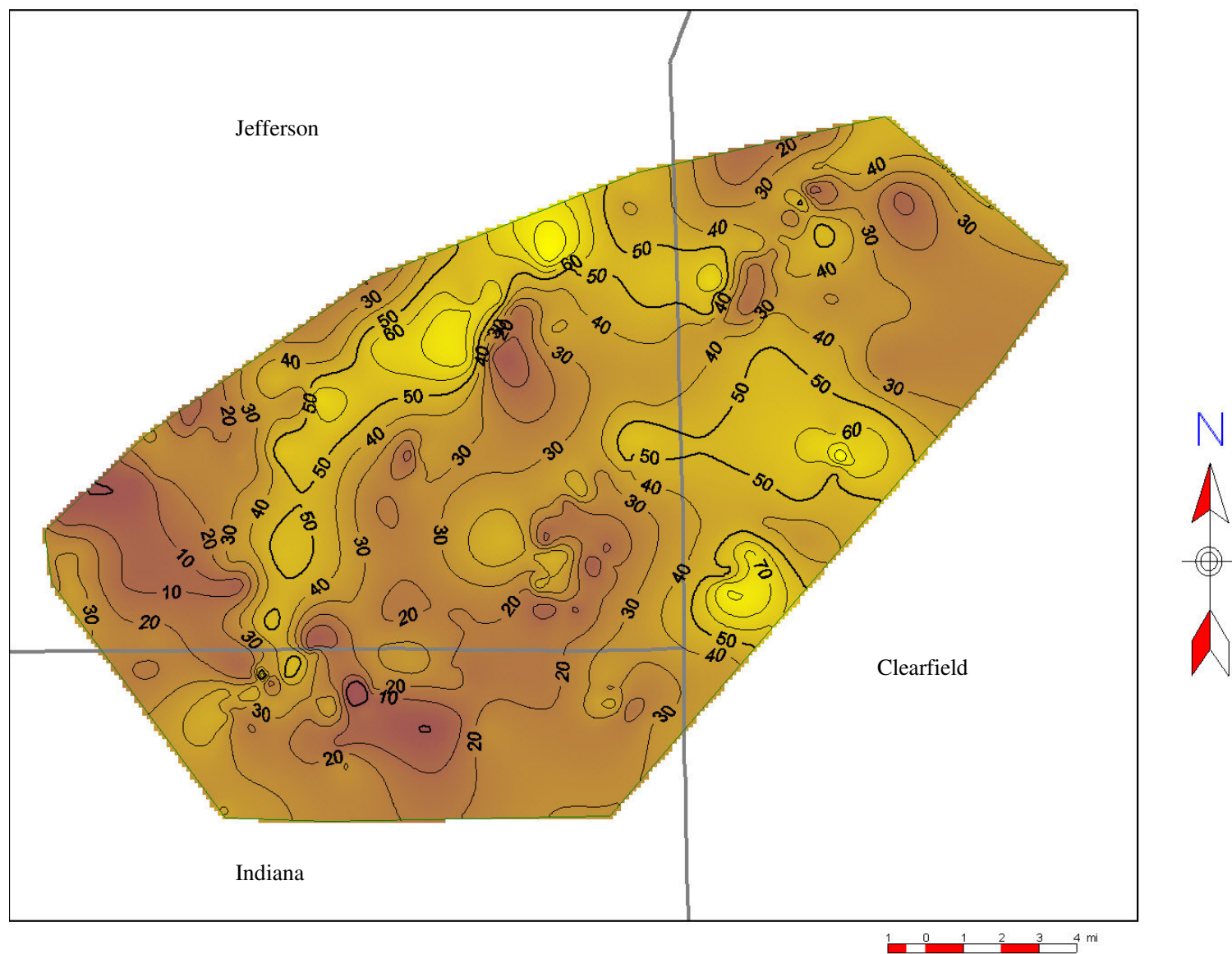

Figure 33-Balltown Zone Net-sandstone Map

Contour Interval $=10 f t$ 


\section{Balltown D Beds}

The Balltown D beds are the lowermost of the Balltown zone, and are up to 110 feet thick (Figure 34). The net-sandstone values of the Balltown D average 15-20 feet thick with a maximum thickness of over 35 feet (Figure 35). Sandstone in the Balltown $\mathrm{D}$ is located in two distinct north-south trends. The net-sandstone map shows a lack of sandstone in several parts of the study area where values drop to zero, and comparison with the isopach map shows that the interval is shale dominated.

I interpret the sandstones to be remnant point bar sands and possible channel lags of multiple rivers through time. These channels eroded into the underlying T1 shale, and the depth of incision increased to the north (Figure 31). The rivers began to flow northward across the study area during the formation of the unconformity at the base of the Balltown D as sea level fell and the foreland ramp was increasingly exposed due to a forced regression of sea level. The change in drainage direction from westward in the Bradford zone to northward in the Balltown zone suggests that some structural tilting in combination with a eustatic sea level fall may have led to the formation of the unconformity at the base of the Balltown zone. Hussing (1994) also observed this kind of syndepositional tectonic activity in his study of the Kane sandstone in the Cush Cushion

Field. Paleotopographic features caused by faulting and folding influenced the depositional trend of the Kane sandstone as well as variations in thickness across paleotopographic highs and lows. 


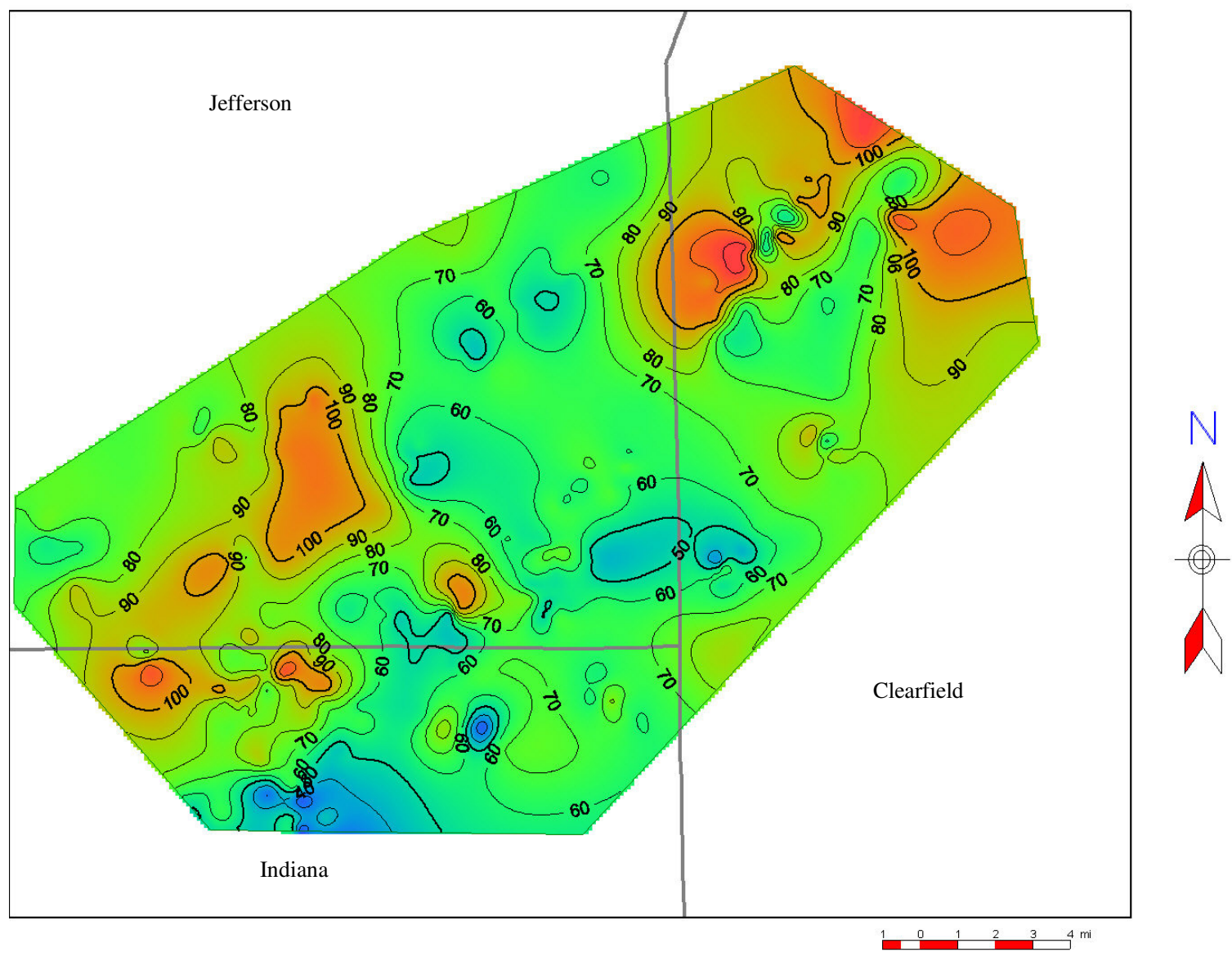

Figure 34-Balltown D Isopach Map

Contour Interval $=10 \mathrm{ft}$ 


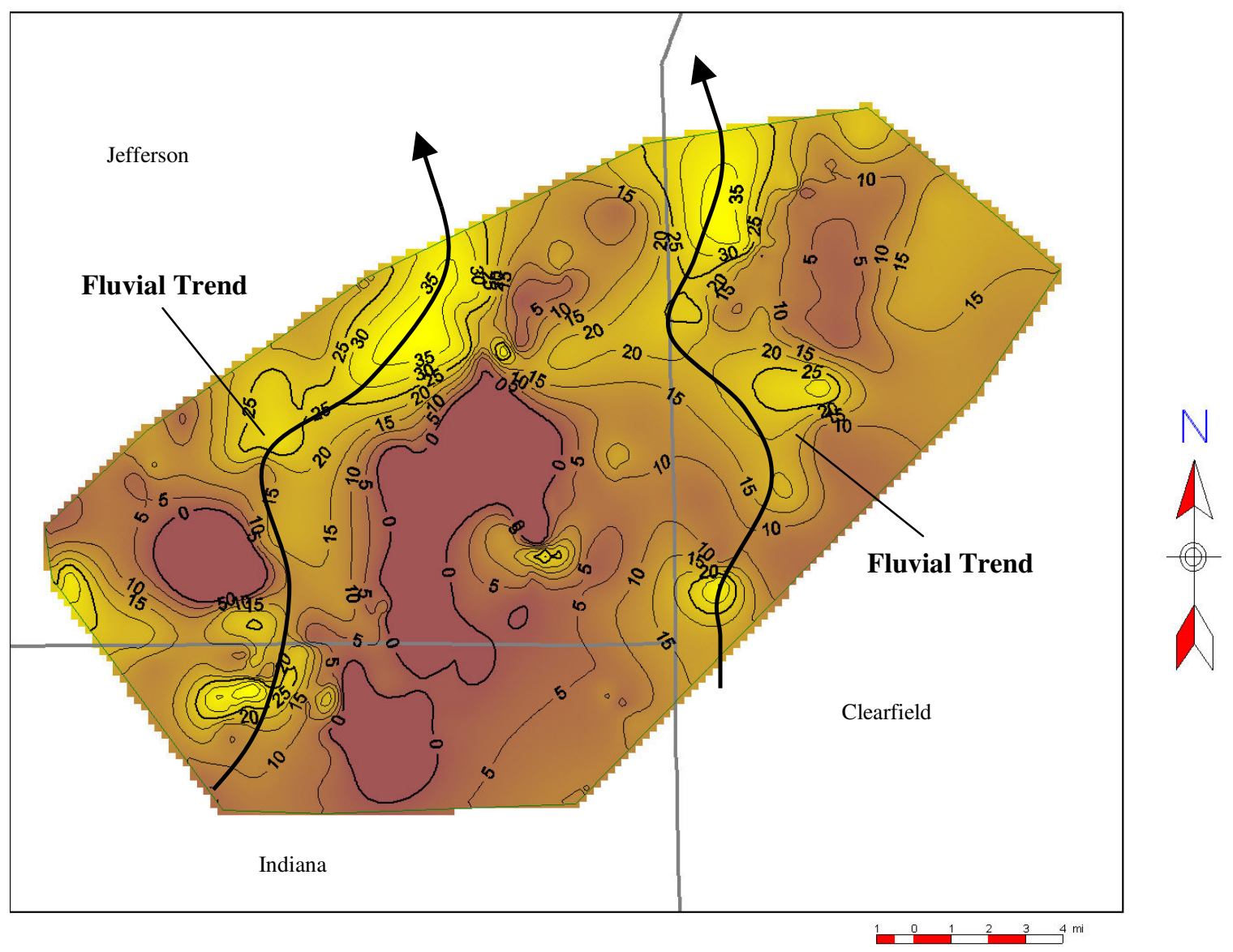

Figure 35-Balltown D Net-sandstone Map

Contour Interval $=5 f t$ 
The beginning of the lowstand systems tract (LST) was marked by the end of the forced regression as eustatic sea level began to rise. Locally, however, relative sea level continued to fall due to the onset of a normal regression as the rate of sedimentation outpaced the rate of eustatic sea level rise (Catuneanu, 2006). During this time, sediments of the LST began to aggrade and fill the incised channels formed during the preceding eustatic fall. The Balltown D interval is composed of these sediments. The unconformity at the base of the Balltown D is observed in cross section (Figure 36) and in map view (Figure 31) to have locally removed over 50 feet of underlying section. Incised valleys such as these have been also been identified by Cotter and Driese (1998) in the Catskill Formation to the east. In my study area a basal sandstone directly overlies the unconformity which is, in turn, overlain by a silty-shale with lenses of sandstone. These beds are on average about 20 to 50 feet thick with the thicker intervals being seen where scouring was the greatest. The upper Balltown D beds, therefore, constitute a fining-upward succession and are topped by a shale that marks the contact with the Balltown C beds (Figure 37). The top of the basal sandstone (LST) is interpreted as a transgressive surface, and the overlying package of shale and siltstone compose the transgressive systems tract (TST) that was deposited when relative sea level rose at a rate higher than that which sediment accumulated. The top of this regionally correlative shale is interpreted as a maximum flooding surface and marks the end of the transgressive systems tract. 


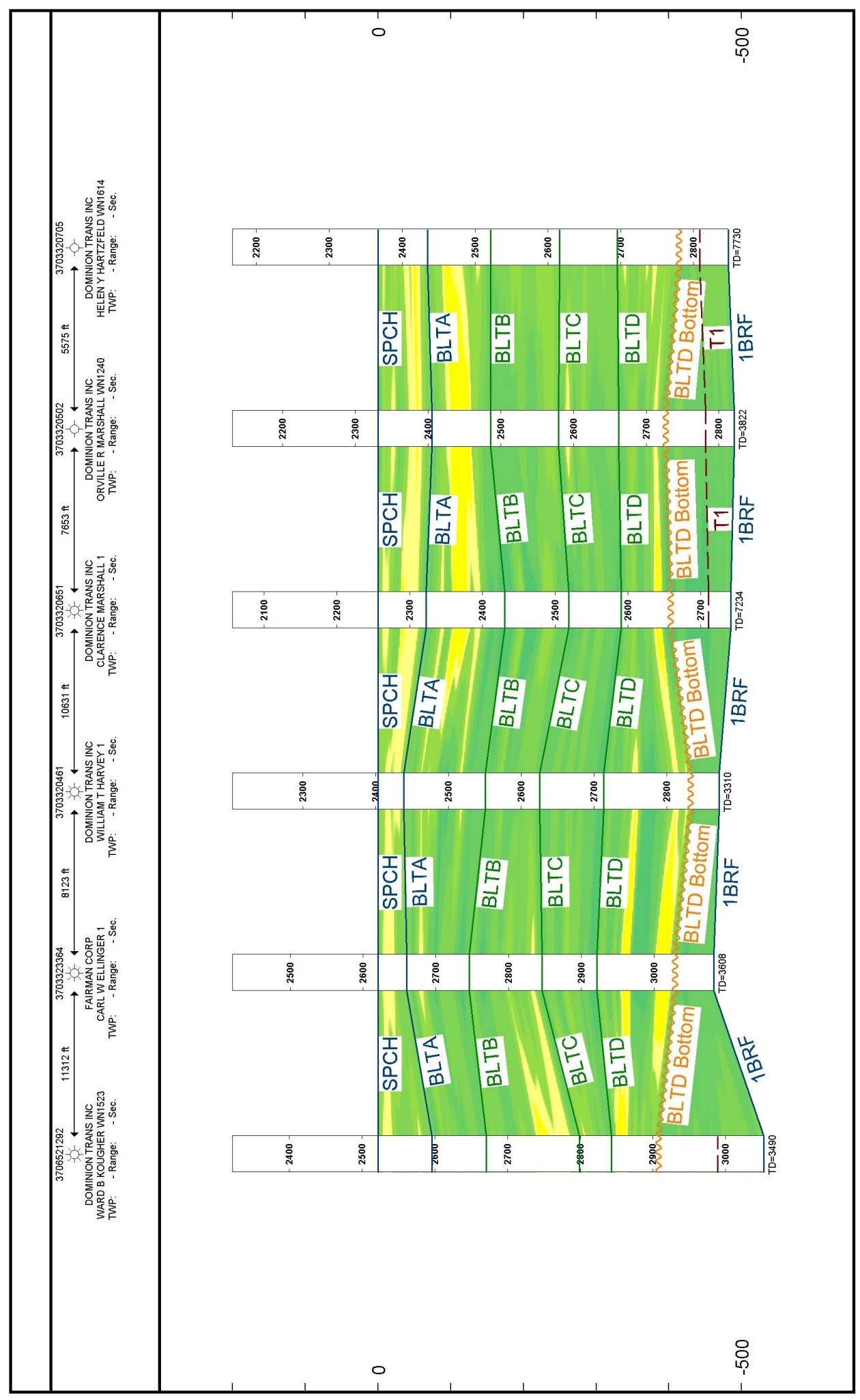

Figure 36- A-A'Dubois Dip Trending Balltown Zone Cross Section

See Figure 12 for location of the cross section. 


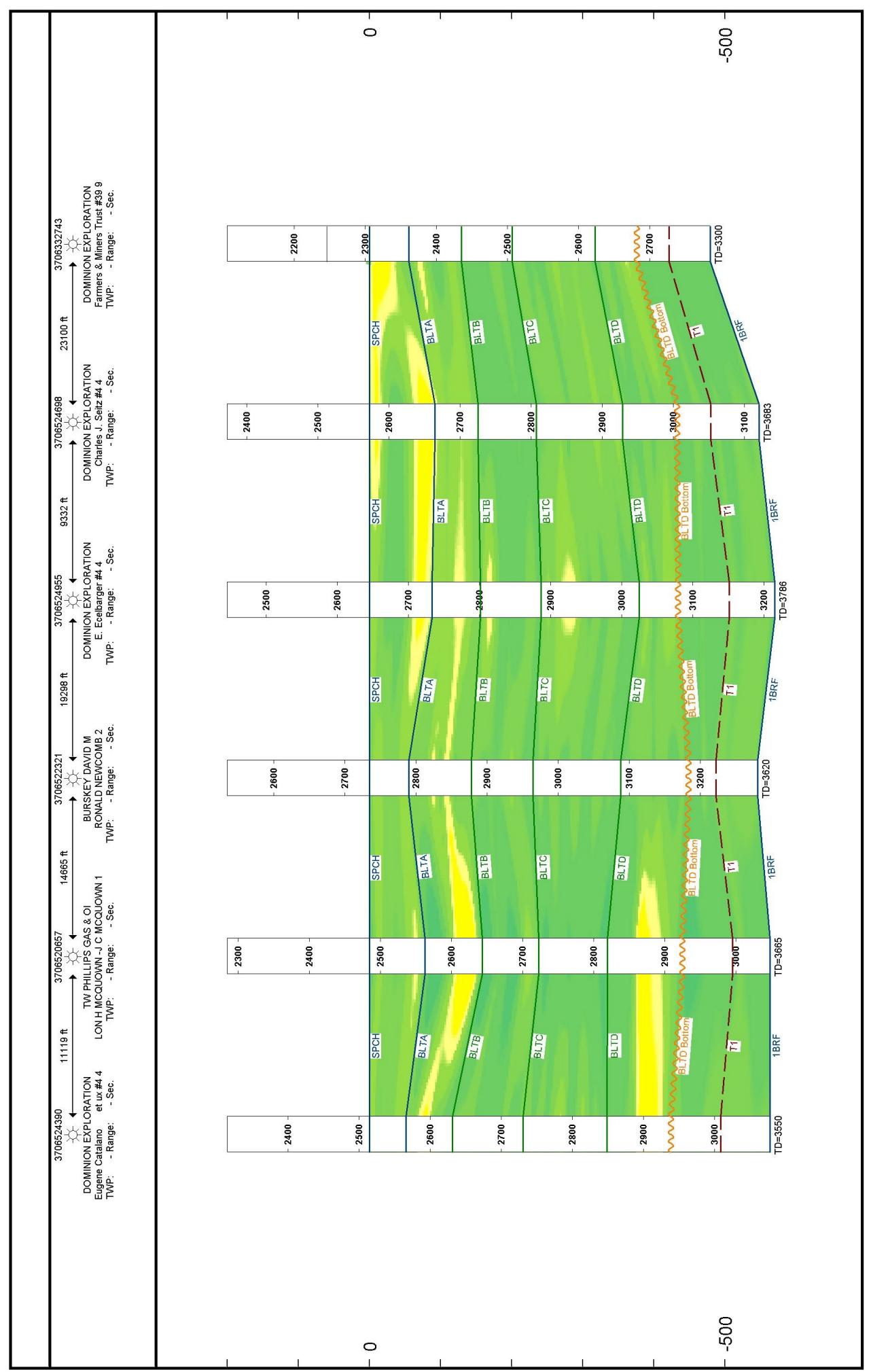

Figure 37-C-C'Northern Punxsutawney Dip Trending Balltown Zone Cross Section

See Figure 12 for location of the cross section. 


\section{Balltown C Beds}

The Balltown $\mathrm{C}$ beds average around 100 feet thick (Figure 38). Most of the sediment in the Balltown $\mathrm{C}$ was deposited in the southern and western parts of the study area. However, the net-sandstone map (Figures 39) shows that the Balltown C sandstone tends to be located in areas where the total interval is generally thin. The map also shows a lobate shape that is composed of radiating fingers. The net-sandstone values average around 10 feet thick with a maximum of 24 feet. 


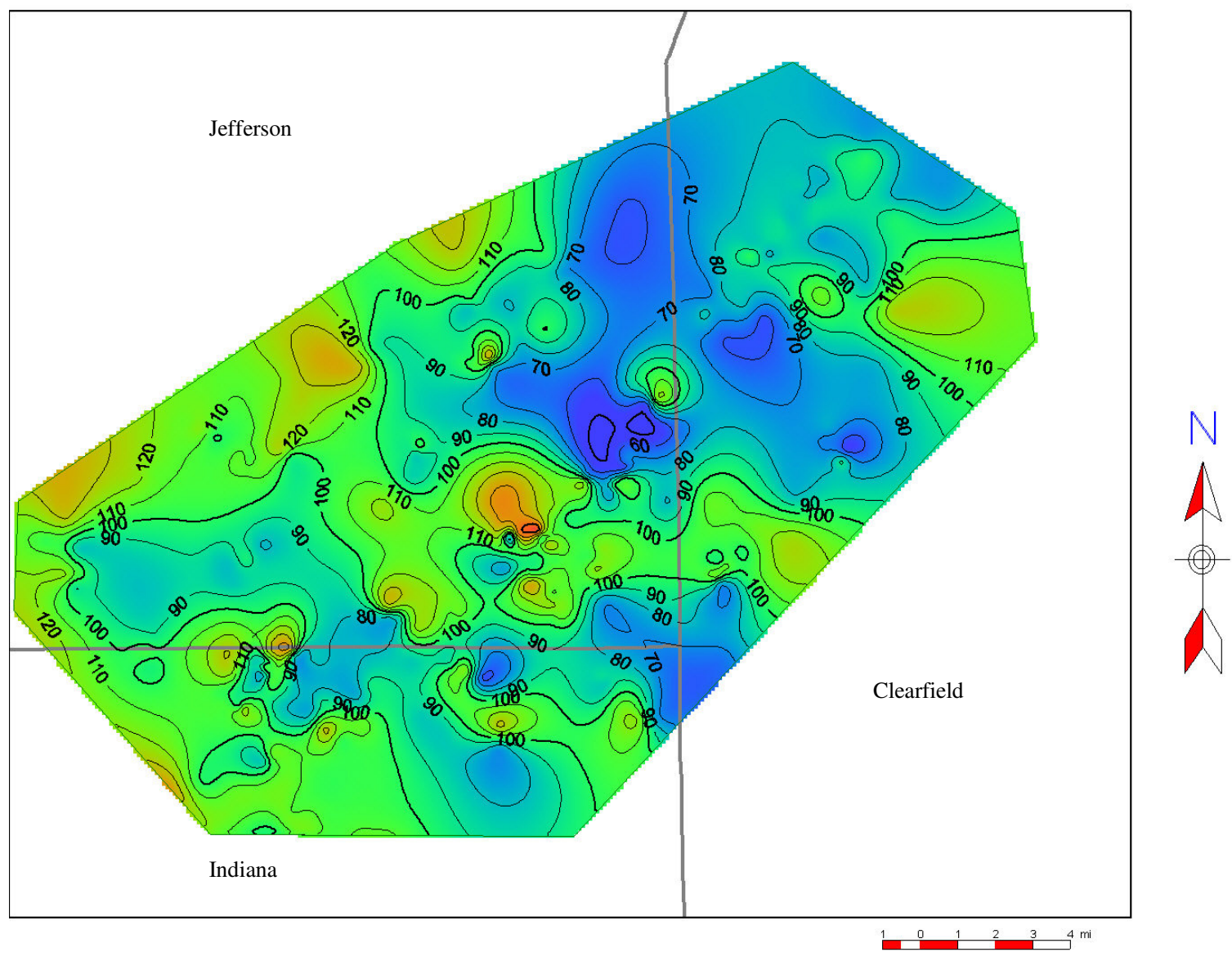

\section{Figure 38-Balltown C Isopach}

Contour Interval $=10 \mathrm{ft}$ 


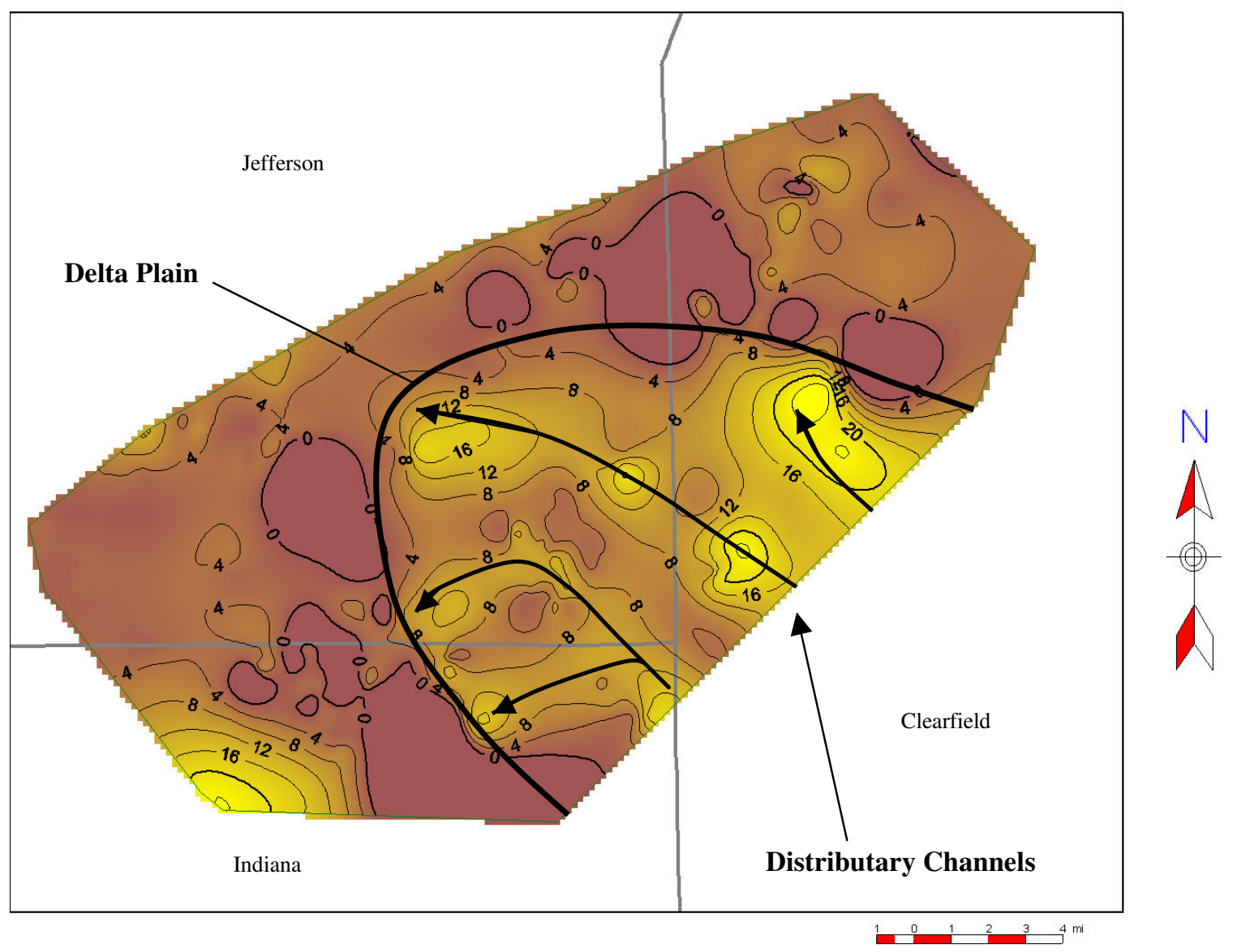

Figure 39-Balltown C Net-sandstone Map

Contour Interval $=4 f t$ 
The Balltown $\mathrm{C}$ sandstone is interpreted to have been deposited within distributary channels of a small prograding delta located in the central part of the study area. The sandstone in these channels is lenticular in cross section and is separated by interdistributary shale of the delta plain (Figure 40). Prodeltaic mud was located in the northern and western part of the study area. The feeder channel through which sediment was transported to the delta was located in the same position as the eastern fluvial channel of Balltown D (Figure 39). Here the Balltown C is interpreted as being part of the early highstand systems tract (HST), deposited during a time in which sea level was still rising but was being outpaced by sedimentation rate. This resulted in a normal regression of sea level with accommodation space being filled near the shoreline and the subsequent progradation of the delta (Catuneanu, 2006). 


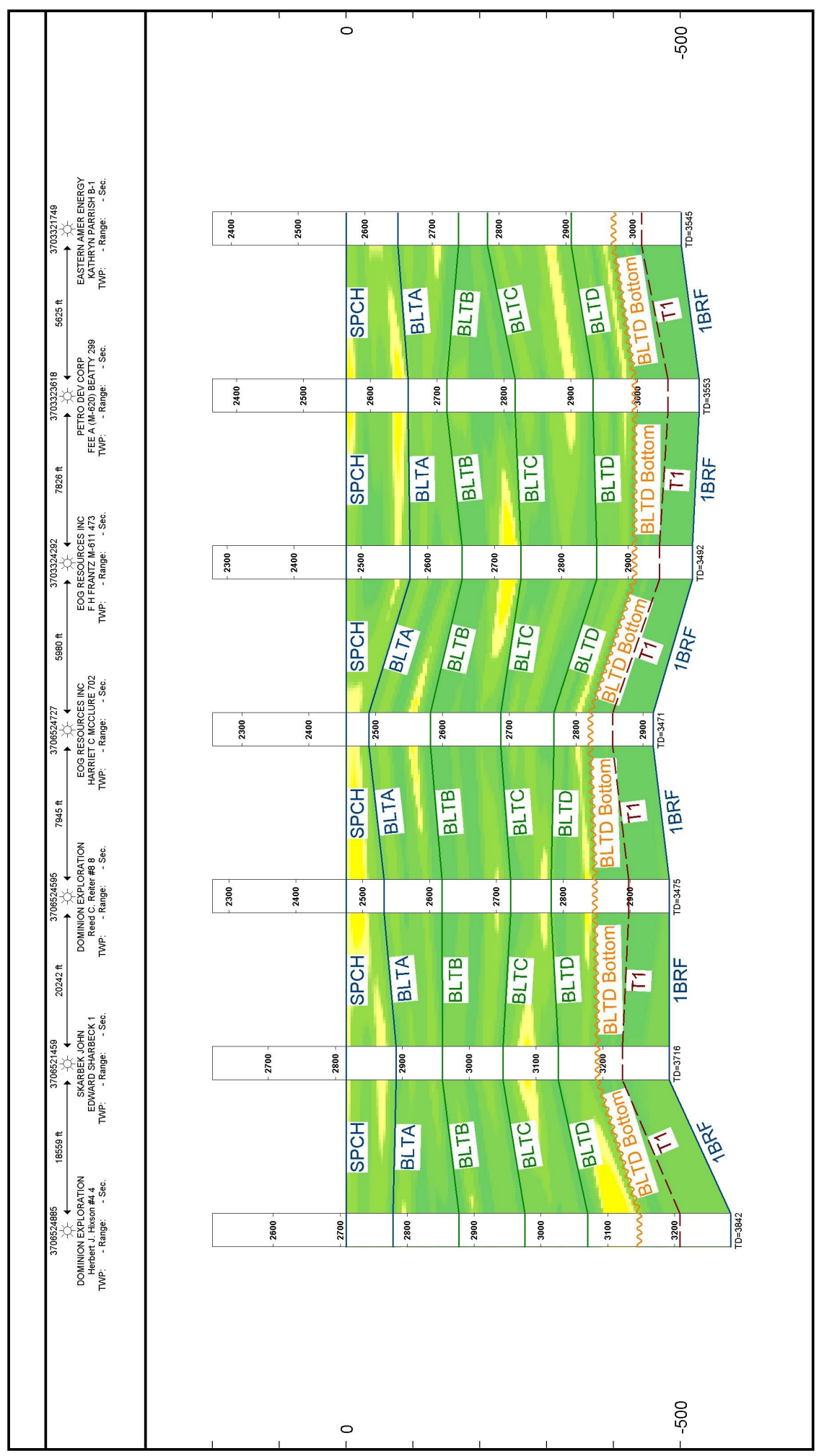

Figure 40-B-B' McGees Mill Dip Trending Balltown Zone Cross Section

See Figure 12 for location of the cross section. 


\section{Balltown B Beds}

The isopach map of the Balltown B beds shows a maximum thickness of over 120 feet with an average 90 feet (Figure 41). The net-sandstone map (Figure 42) shows average values of 5 to 10 feet thick, a maximum value of 20 feet, and large areas in the eastern and western parts of the study area with no sandstone. This map shows a distinct lobe of sandstone of the Balltown B located slightly northward of the sandstone lobe in the underlying Balltown $\mathrm{C}$ beds. The Balltown $\mathrm{B}$ interval as a whole is predominately composed of shale, and sandstone composes only a small percent of the interval. The predominance of shale and the lack of sandstone is observable in cross section (Figure 43). Where sandstone is present, it occurs in localized lenticular-shaped beds (Figure 40). 


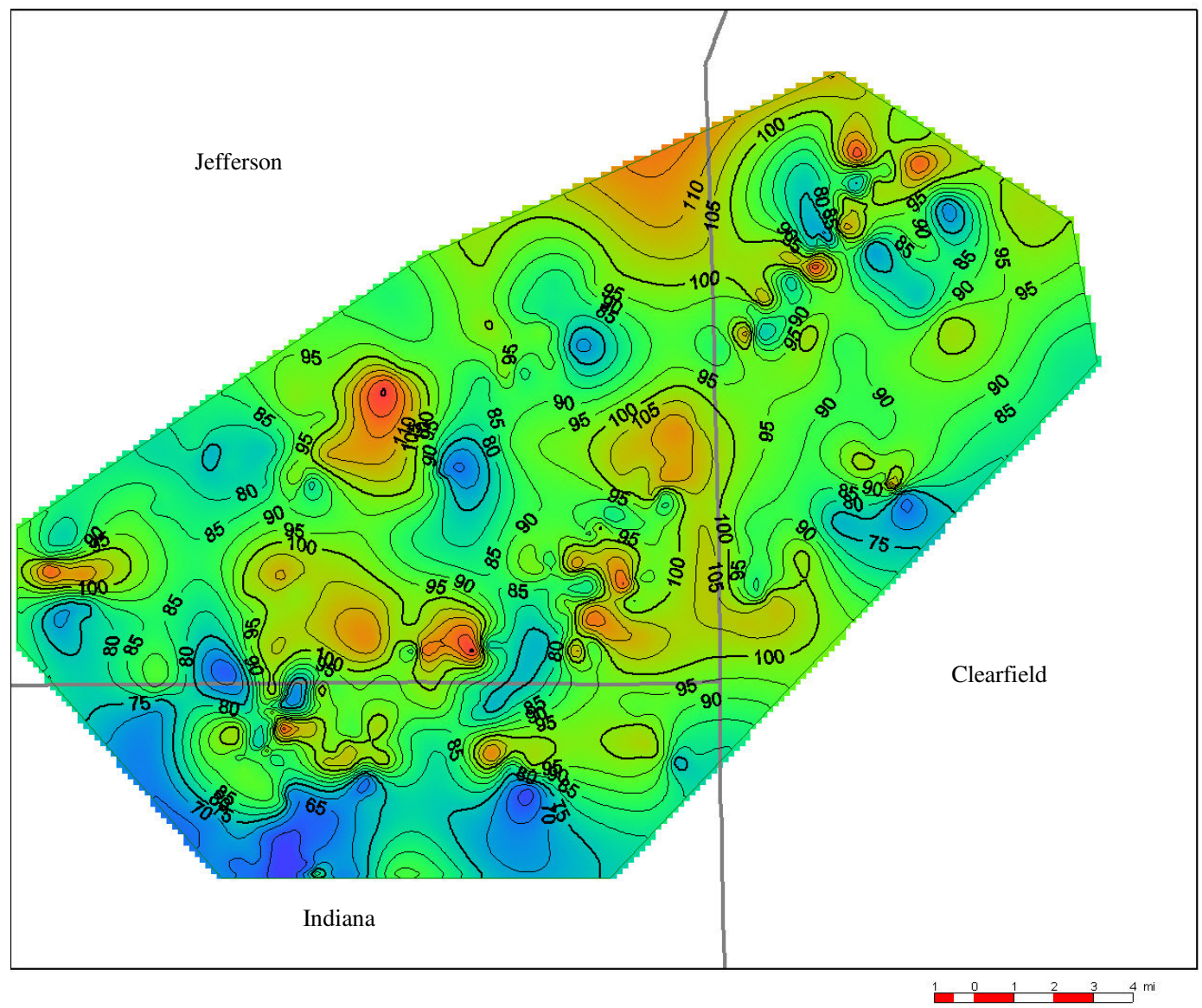

\section{Figure 41-Balltown B Isopach Map}

Based on the net-sandstone interpretations the orange-red shale thicks are inferred to be representative of interdistributary bays.

Contour Interval $=5 f t$ 


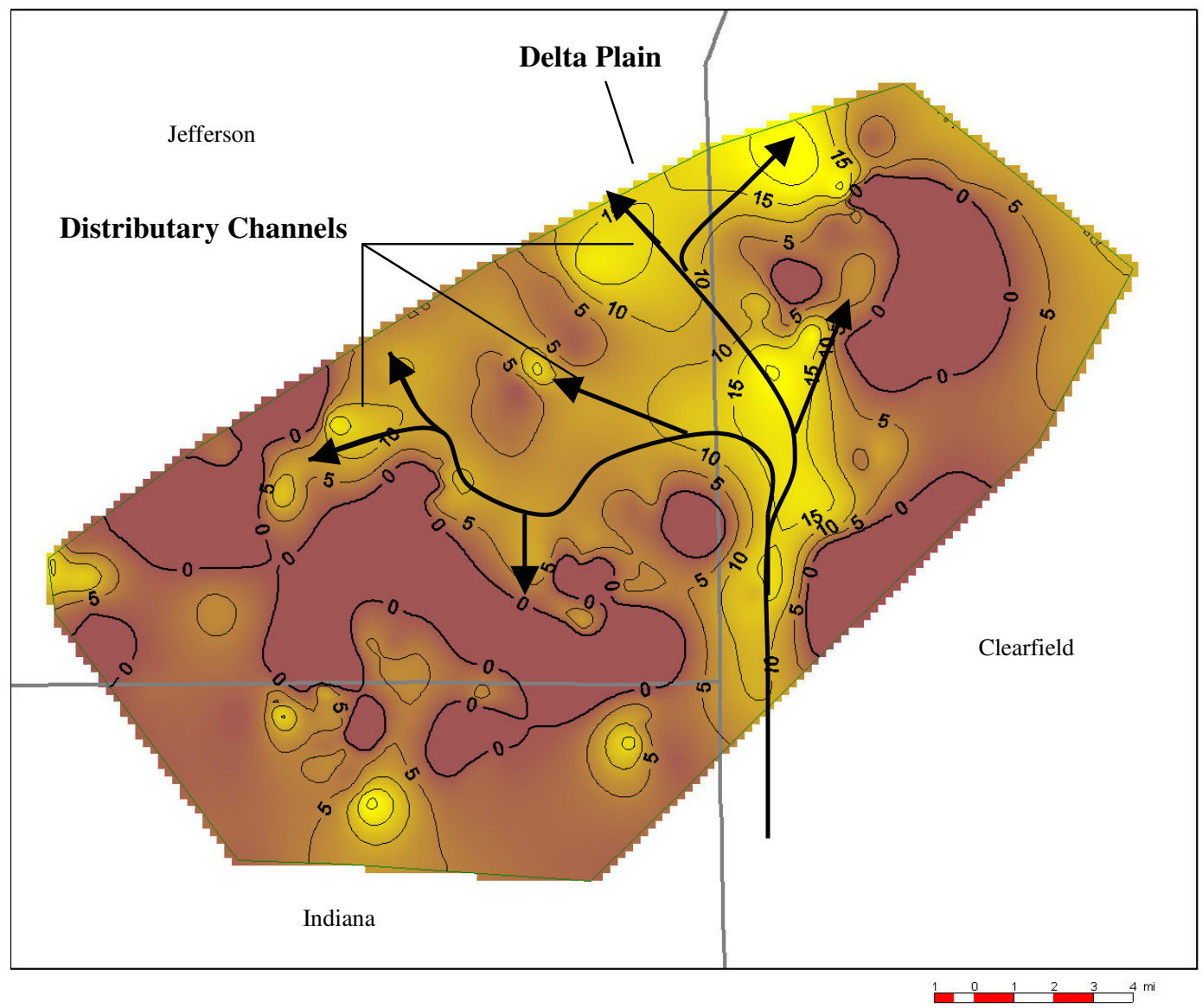

Figure 42-Balltown B Net-sandstone Map

Contour Interval $=5 f t$ 


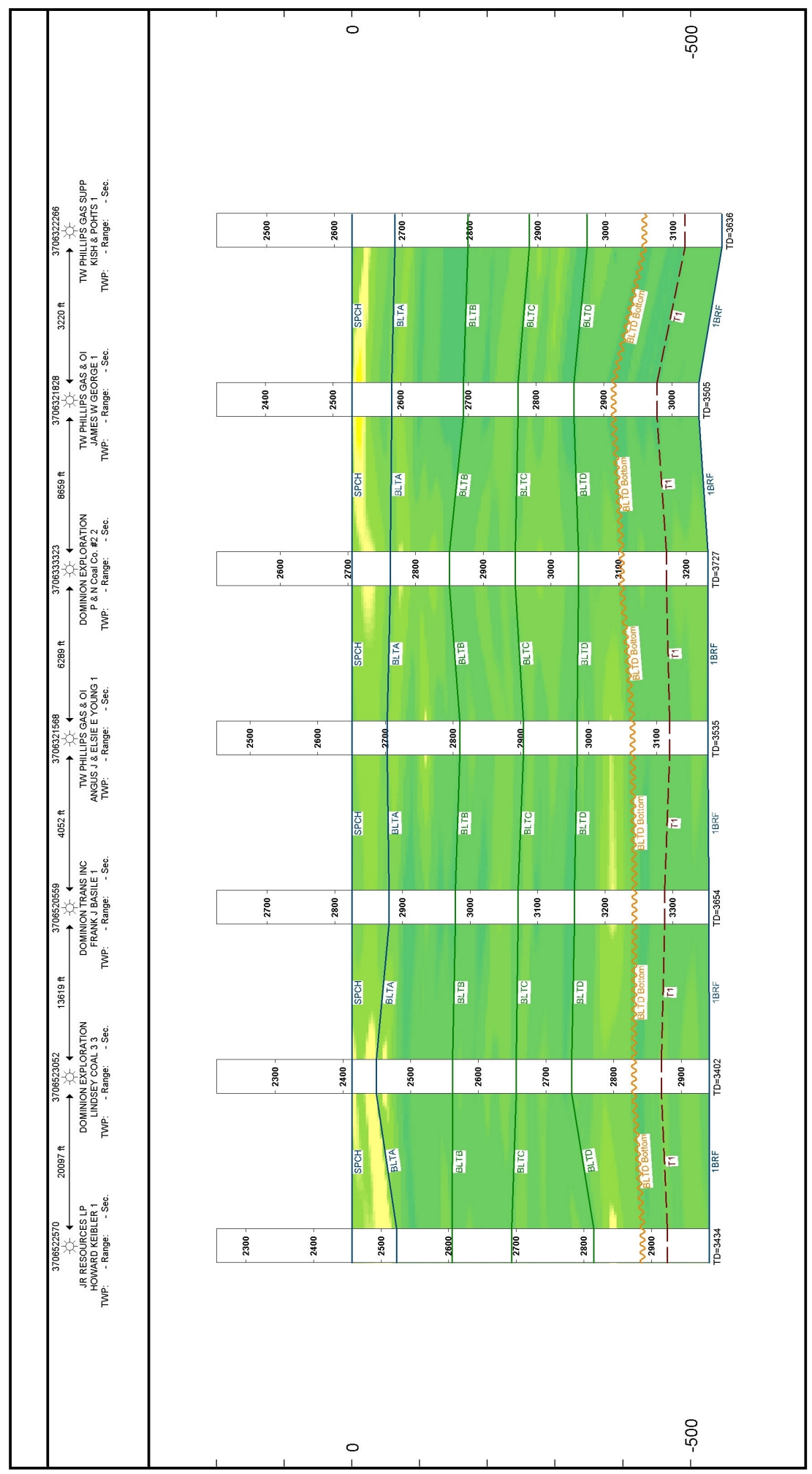

Figure 43-D-D' Southern Punxsutawney Dip Trending Balltown Zone Cross Section

See Figure 12 for location of the cross section. 
Sandstones of the Balltown B are interpreted as being deposited within distributary channels of the delta plain (Figure 41) separated by shale-dominated interdistributary bays (Figure 42). There is also a possible second delta in the southwestern part of the study area, but too much of that sediment body is located off the map. The deltaic-nearshore facies of the Balltown B and Balltown C are similar to those in the Sherman Creek and Irish Valley Members of the Catskill Formation. In eastern outcrops these members contain light gray, cross-laminated sandstone and green-gray, fissile mudrock representative of fluvial and shallow-marine nearshore environments respectively (Cotter and Driese, 1998). During this time any effects of eustatic sea-level rise were overwhelmed by the high rate of deltaic sedimentation within the study area, which caused relative sea level to continue dropping as accommodation space filled. The Balltown B is interpreted to represent continued deposition of deltaic sediment in the late HST resulting in the N-NW progradation of the delta, compared to the earlier location of the Balltown $\mathrm{C}$ beds. Continued normal regression during the late HST resulted in the lengthening of streams as they crossed the delta plain, and transport of sediment farther basinward. 


\section{Balltown A Beds}

The Balltown A is the fourth sandstone in the Balltown zone, and overlies the deltaic deposits of the Balltown B interval. The Balltown A averages approximately 80 feet thick (Figure 44), and has net-sandstone values that average around 10 to 15 feet thick (Figure 45). The sandstone trend of the Balltown A strikes in a north-northwest direction, and occurs in the same general location as the trend seen in the Balltown B isopach map (Figure 41). The Balltown A beds are different from the Balltown B in that the isopach thicks correlate geographically to the net-sandstone values. In cross section (Figure 46) the Balltown A is composed of thin lenticular sandstones interbedded with shale in the southern and western part of the study area. However, the most easterly sandstone is thicker and more channel-form than other sandstones of the Balltown A beds. 


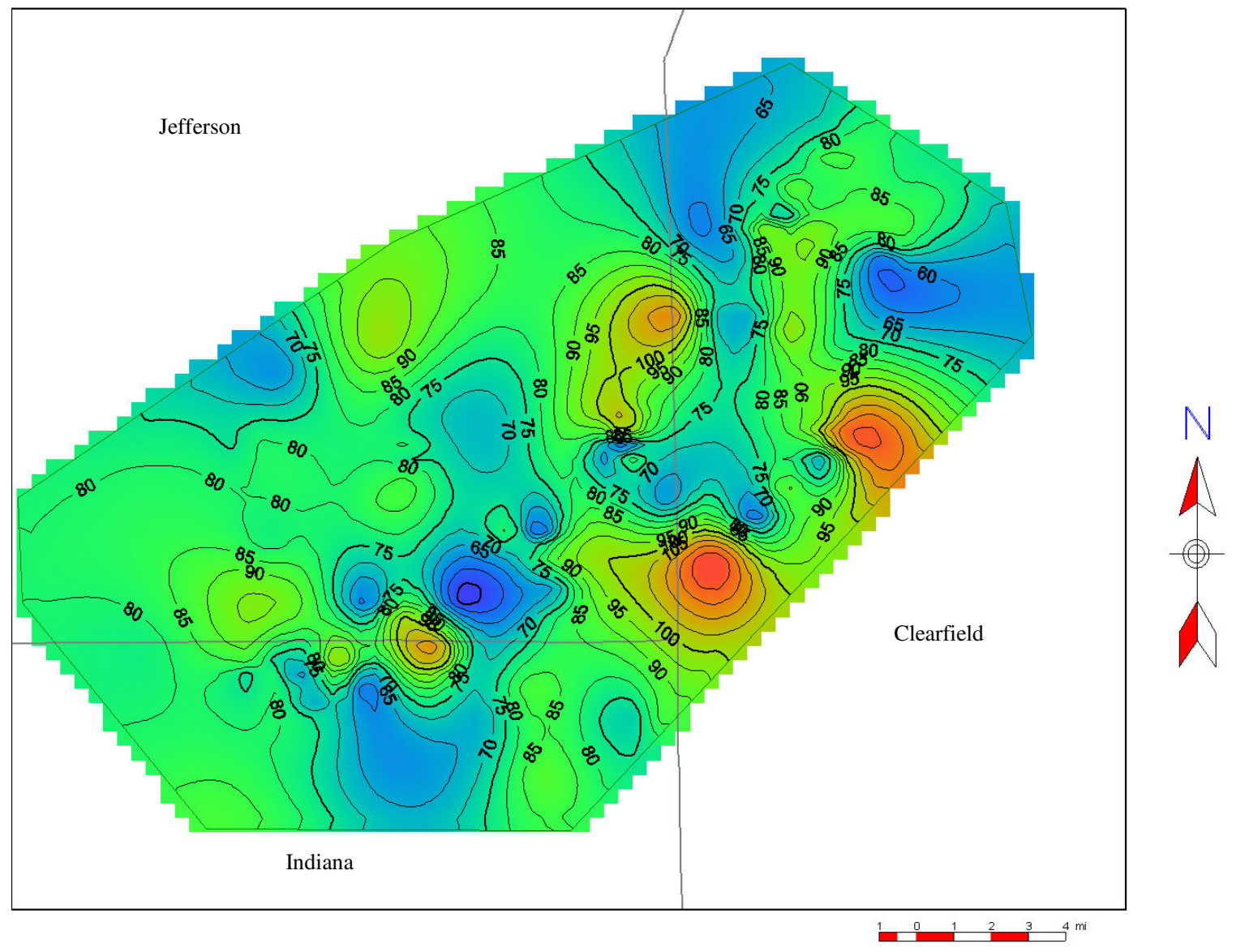

Figure 44 -Balltown A Isopach Map

Contour Interval $=5 f t$ 


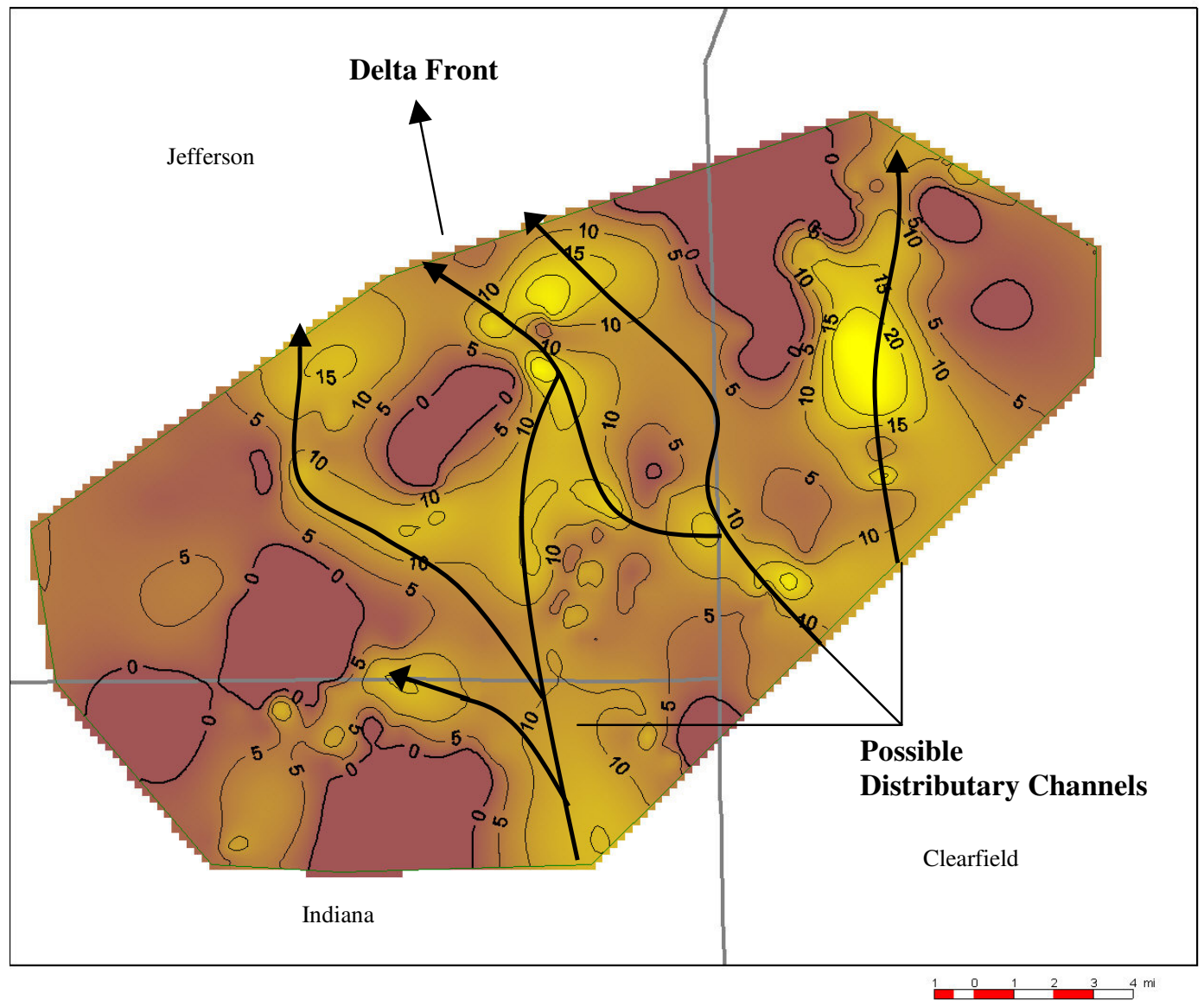

N

Figure 45-Balltown A Net-sandstone Map

Contour Interval $=5 f t$ 


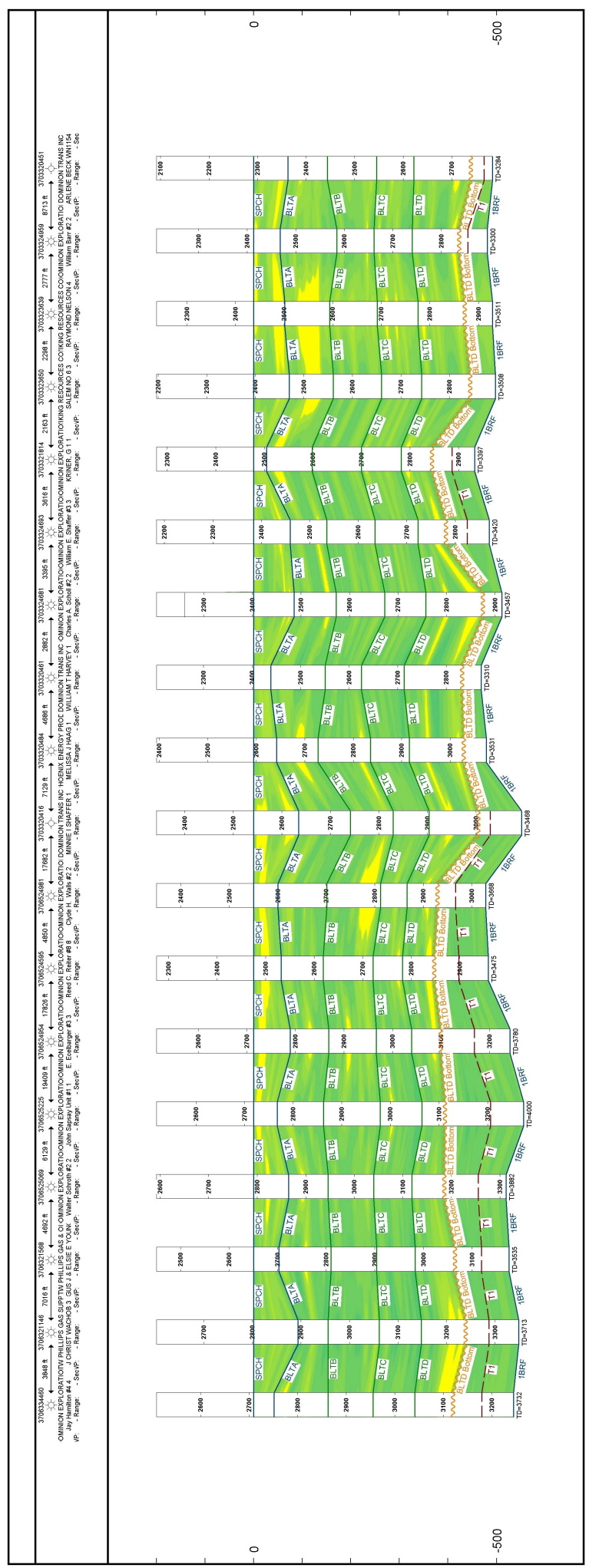

Figure 46-E-E' Balltown Zone Strike Cross Section

See Figure 12 for location of the cross section. 
The sandstones of the Balltown A show a similar distributary pattern as seen in previous intervals of the Balltown zone (B and C), and are interpreted to be representative of distributary channels on the delta plain. The isopach map of the Balltown A beds also shows these distributary trends. This suggests that accommodation space was beginning to become limited on the delta plain, and that sediment was being deposited in the more isolated channels. However, the Balltown A does not display any further seaward progradation of the delta from shorelines established in the Balltown $\mathrm{C}$ and $\mathrm{B}$ beds. Rather, the focus of deposition of the Balltown A beds shifted laterally to the west as the rate of base level rise decreased and accommodation space was filled (Catuneanu, 2006). During this time, the rate of the normal regression of sea level began to slow due to the more lateral and less basinward deposition of sediment late in the HST. 


\section{Speechley Beds}

The Speechley beds are the uppermost unit of the Balltown zone and contain the last major drillers' sandstone of the Bradford zone in the Greater Punxsutawney Area. The Speechley isopach map (Figure 47) shows that the average thickness of the unit is about 70 feet thick. The Speechley beds are thickest in the eastern part of the study area with a maximum thickness of over 120 feet thick, and the thinnest part of the interval is in the southern part of the study area where values dip as low as 40 feet thick. The netsandstone values of the Speechley interval are greater than those seen in the underlying three intervals of the Balltown zone (A, B, and C) with thicknesses averaging around 20 feet thick but reaching over 34 feet thick (Figure 48). In the study area, approximately $20 \%$ of the Speechley beds are composed of sandstone, while the previous three intervals were composed of approximately $10 \%$ sandstone and had average net-sandstone values of around 10 feet thick. In cross section the Speechley interval is also seen to comprise sandstones that are more laterally continuous than those in underlying Balltown beds (Figure 36). However, above the Speechley beds are interbedded sandstones and shales that change from gray to red beds. The transition from gray to red beds is observed in drillers' logs within the study area (Figure 49), but are sometimes inconclusive as to the depth of this transition due to the lack of sample collecting by most drillers. 


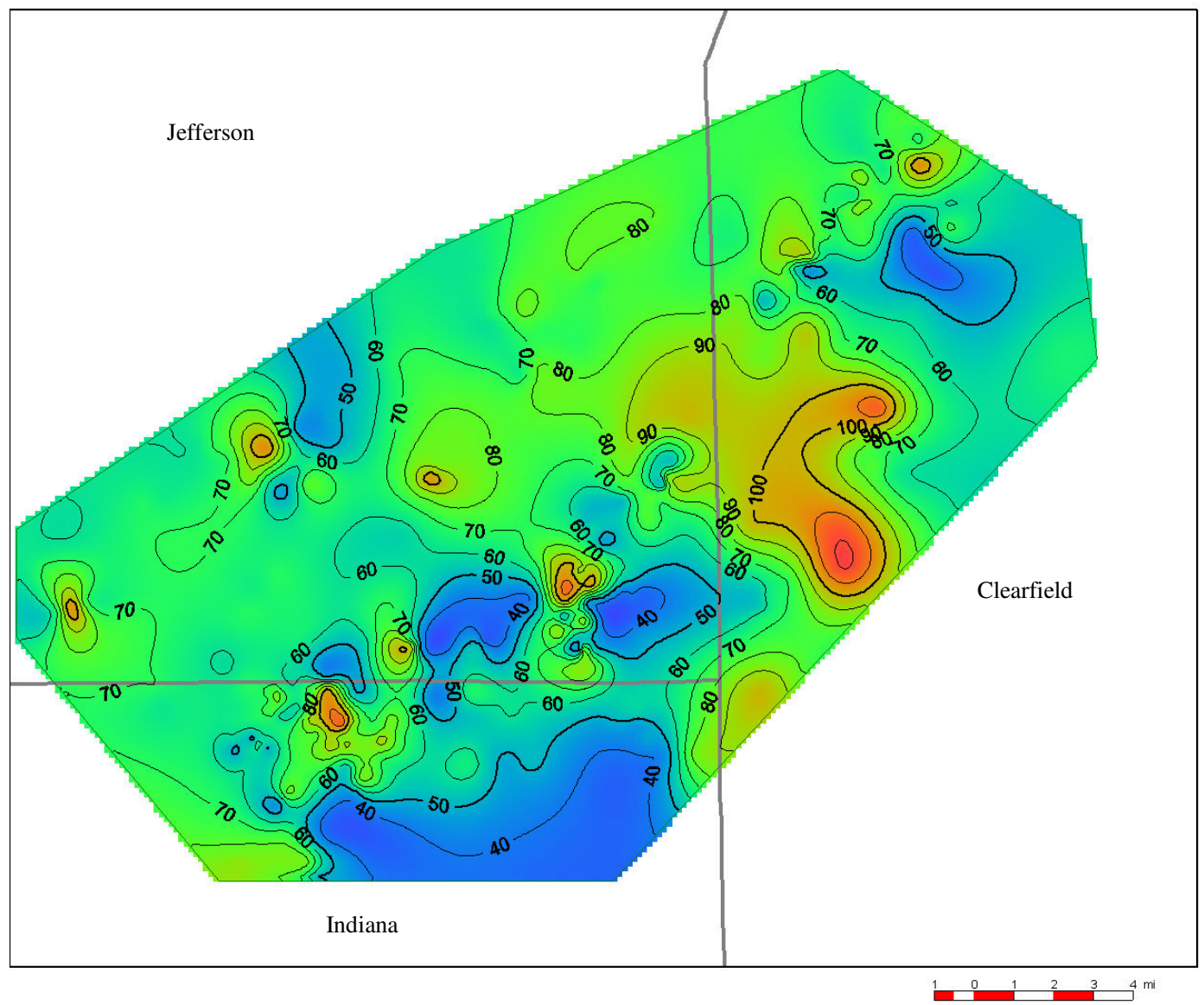

N

Figure 47 -Speechley Isopach Map

Contour Interval $=10 \mathrm{ft}$ 


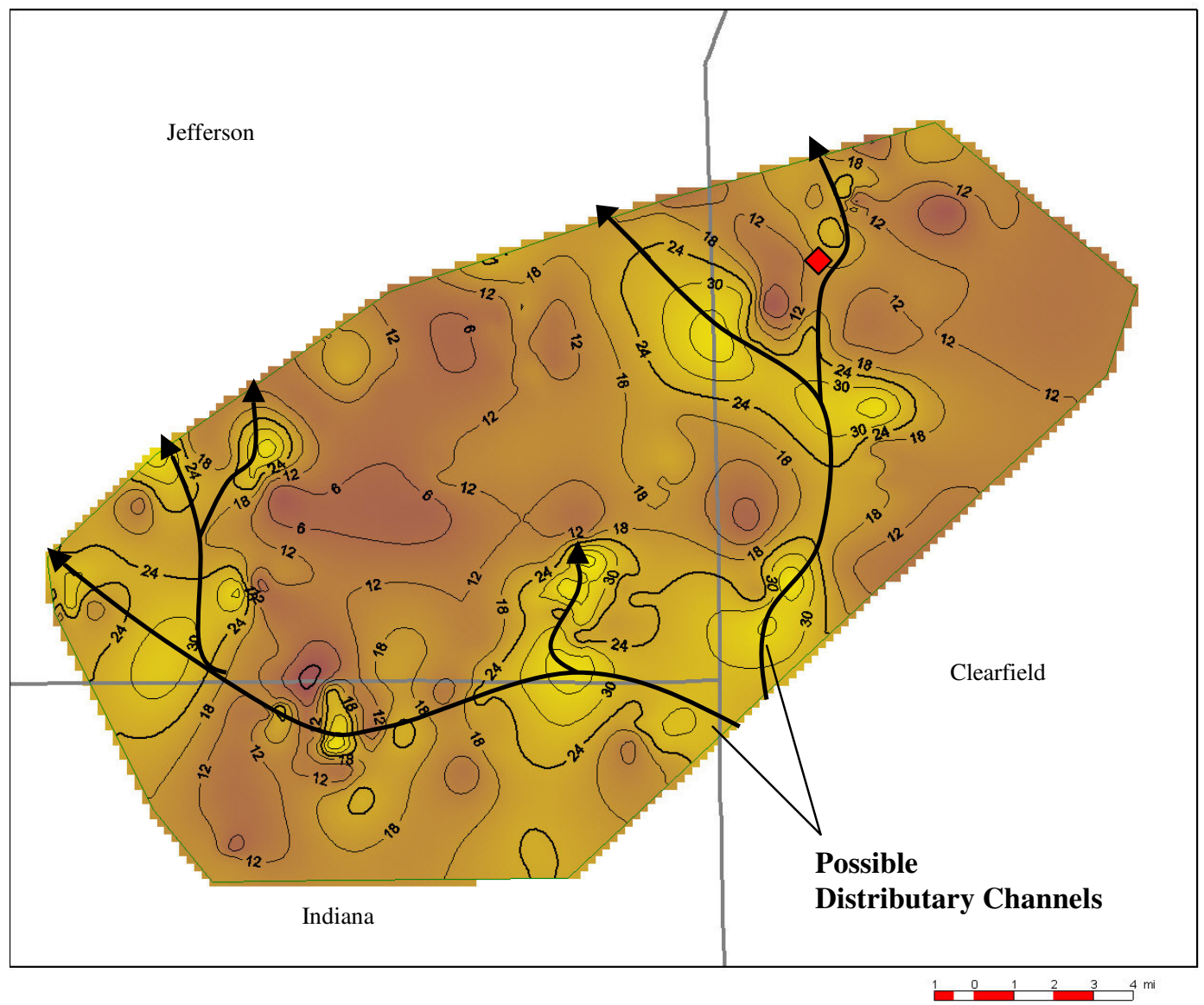

Figure 48-Speechley Net-sandstone Map

Contour Interval $=6 f t$

$\diamond=$ Well \#37-033-24694 


\begin{tabular}{|c|c|c|c|c|c|c|c|c|}
\hline & \multicolumn{4}{|c|}{ LOG OF FORMATIONS } & \multicolumn{4}{|c|}{ Well APIN 37-033-24694 } \\
\hline Formation Name or Type & $\begin{array}{l}\text { Top } \\
\text { (feetl }\end{array}$ & $\begin{array}{c}\text { Bottom } \\
\text { (teet) }\end{array}$ & $\begin{array}{c}\text { Gas at } \\
\text { (feot) }\end{array}$ & $\begin{array}{l}\text { Oll at } \\
\text { (feet) }\end{array}$ & $\begin{array}{c}\text { Water at } \\
\text { (tresh / bone, it) }\end{array}$ & Sol & urce 0 & f Data \\
\hline $\begin{array}{l}\text { Let down } \\
\text { brown shale } \\
\text { brown sandy shale } \\
\text { gray sandy shale } \\
\text { black coal } \\
\text { gray shale } \\
\text { black coal } \\
\text { black shale } \\
\text { gray sand } \\
\text { black shale } \\
\text { black coal } \\
\text { black shale } \\
\text { gray sand } \\
\text { redrock } \\
\text { gray sand } \\
\text { red sand \& shale } \\
\text { gray sand } \\
\text { red \& gray sand } \\
\text { gray sand } \\
\text { gray shale } \\
\text { gray sand \& shele } \\
\text { gray shale } \\
\text { gray sand \& shale } \\
\text { gray sand } \\
\text { gray sand \& shale } \\
\text { gray shale } \\
\text { gray sand } \\
\text { red \& gray shale } \\
\text { gray shale } \\
\text { redrock } \\
\text { gray sandy shale } \\
\text { redrock } \\
\text { gray sandy shale } \\
\text { gray sand } \\
\text { gray sandy shale } \\
\text { redrock } \\
\text { gray sandy shale } \\
\text { gray sand } \\
\text { gray sandy shale } \\
\text { gray sand } \\
\text { gray sandy shale } \\
\text { gray sand } \\
\text { gray shale } \\
\text { gray sandy shale } \\
\text { gray shale } \\
\end{array}$ & $\begin{array}{r}0 \\
5 \\
10 \\
25 \\
75 \\
80 \\
100 \\
102 \\
115 \\
240 \\
275 \\
278 \\
315 \\
625 \\
680 \\
815 \\
825 \\
840 \\
870 \\
895 \\
905 \\
920 \\
930 \\
950 \\
1050 \\
1180 \\
1270 \\
1365 \\
1400 \\
1460 \\
1655 \\
1685 \\
1740 \\
1835 \\
1935 \\
2200 \\
2240 \\
2430 \\
2485 \\
2640 \\
2720 \\
3260 \\
3290 \\
3400 \\
3470\end{array}$ & $\begin{array}{r}5 \\
10 \\
25 \\
75 \\
80 \\
100 \\
102 \\
115 \\
240 \\
275 \\
278 \\
315 \\
625 \\
680 \\
815 \\
825 \\
840 \\
870 \\
895 \\
905 \\
920 \\
930 \\
950 \\
1050 \\
1180 \\
1270 \\
1365 \\
1400 \\
1460 \\
1655 \\
1685 \\
1740 \\
1835 \\
1935 \\
2220 \\
2240 \\
2430 \\
2485 \\
2640 \\
2720 \\
3260 \\
3290 \\
3400 \\
3470 \\
3510\end{array}$ & & $\begin{array}{l}\text { Bottom } \\
\text { Speech }\end{array}$ & f red beds @ top @ 2402 & 40 & 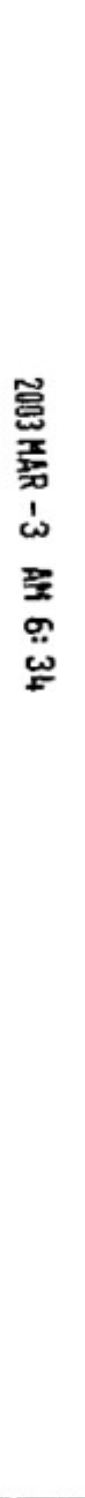 & 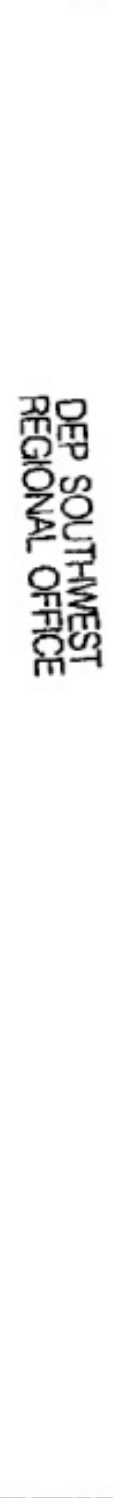 \\
\hline
\end{tabular}

Figure 49_Drillers' Log of Well \#37-033-24694

The top of the Speechley drillers' sandstone is at 2402'. 
The Speechley is here interpreted to have been deposited in the latest HST during a time when the avulsion of the distributary channels on the delta plain caused sediment to be dispersed laterally. The distributary channels of the Speechley interval, as compared to the Balltown A, show that the delta was continuing to shift westward as the thickness and percentage of sandstone increased. Red beds are typically reported approximately 200 feet above the Speechley beds (Figure 49), but the interval varies as much as 40 feet due to the lack of accuracy of the drillers' logs. These red beds are assigned to the Catskill Formation, which has been interpreted to be representative of non-marine fluvial environments (Cotter and Driese, 1998), and mark a continuation of the highstand systems tract. However, a lack of subsurface data forces the study to end at the top of the Speechley beds. 


\section{DESCRIPTION AND INTERPRETATION OF NET-PAY MAPS}

The net-pay maps constructed for the Bradford Group, Bradford zone, Balltown zone, and each individual drillers' sandstone are helpful tools for identifying potential locations for the future drilling of gas wells. This is especially helpful in the Bradford Group where secondary porosity due to the diagenetic leaching of metamorphic and lithic fragments is present (Smosna and Bruner, 1997). The gamma-ray curve may indicate a sandstone zone with low API units, but compaction and the loss of primary porosity may render the zone to be unproductive. Therefore, the net-pay maps, used in conjunction with the net-sandstone maps, help to identify potential gas-producing zones, and reinforce the trends seen in the net-sandstone maps.

The Bradford zone net-pay maps (Figures 50-54) show the same trends but are only about 10 feet thinner than the values seen in the net-sandstone maps. This correlation of net-sandstone to net-pay indicates that the occurrence of porosity within the reservoirs correlates very well to the presence of sandstone within the Bradford zone. However, permeability in the sandstones of the First Bradford was measured at less than 0.01 millidarcy (Murin, 1988). Both Murin (1988) and Hussing (1994) concluded that structural features are important to understanding permeability and reservoir potential in the Bradford zone of west-central PA. Fractures, such as those observed by Murin (1988) in core plugs, may have been vital pathways for the migration of the fluids that were responsible for the leaching of lithic and metamorphic fragments and the creation of secondary porosity within these reservoirs (Smosna and Bruner, 1997). 


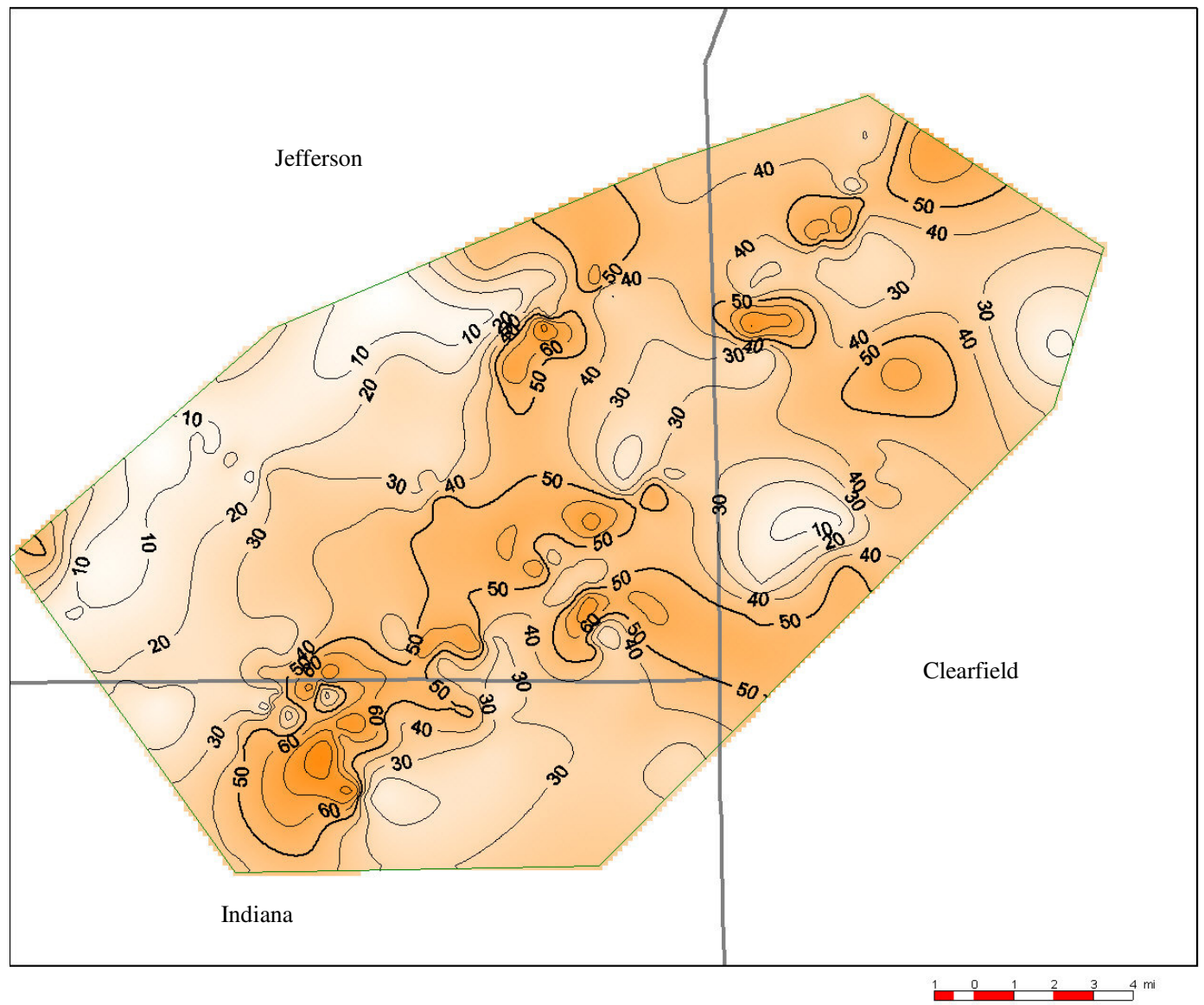

Figure 50_Bradford Zone Net-Pay Map

Reference: Bradford zone net-sandstone map (Figure 16)

Contour Interval $=10 \mathrm{ft}$ 


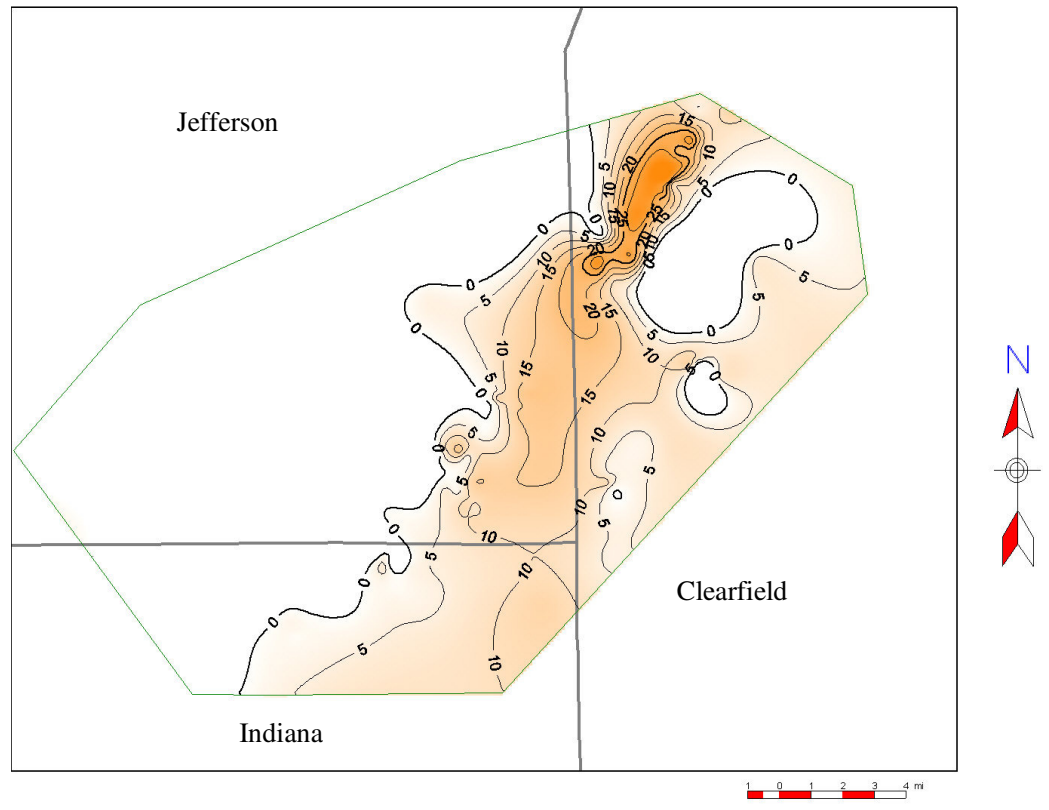

Figure 51-Kane Net-Pay Map

Reference: Kane net-sandstone map (Figure 17)

Contour Interval $=5 f t$

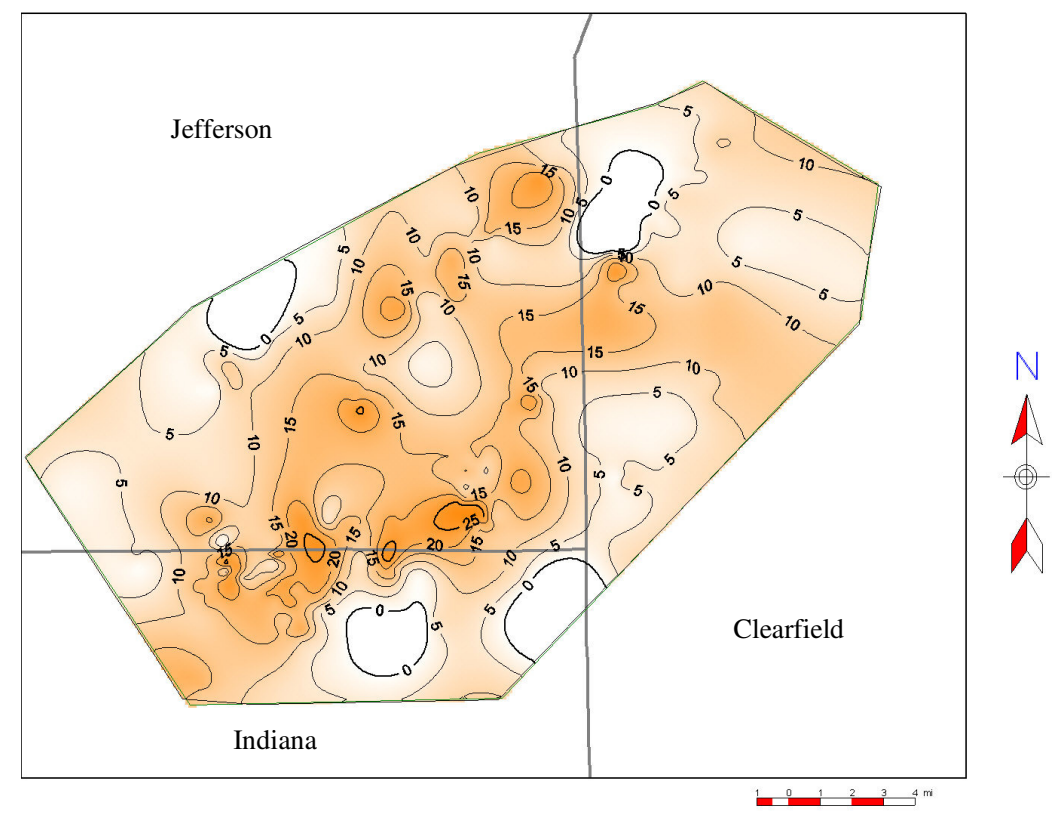

Figure 52-Third Bradford Net-Pay Map

Reference: Third Bradford net-sandstone map (Figure 23)

Contour Interval $=5 f t$ 


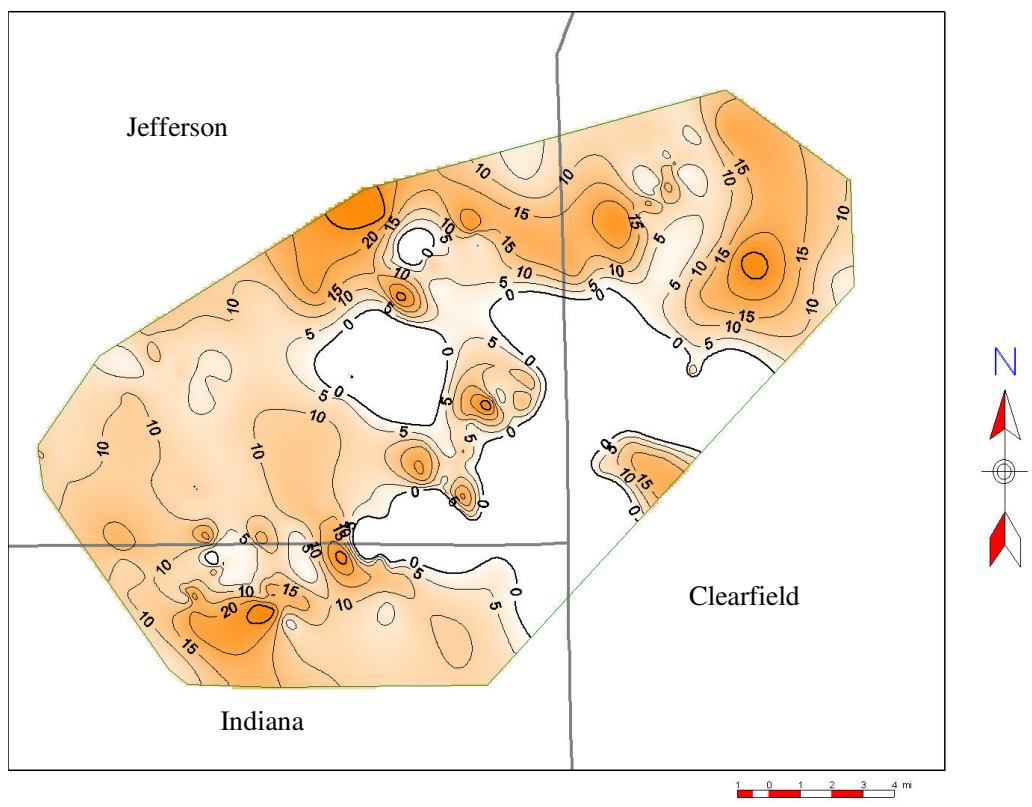

Figure 53-Second Bradford Net-Pay Map

Reference: Second Bradford net-sandstone map (Figure 26)

Contour Interval $=5 f t$

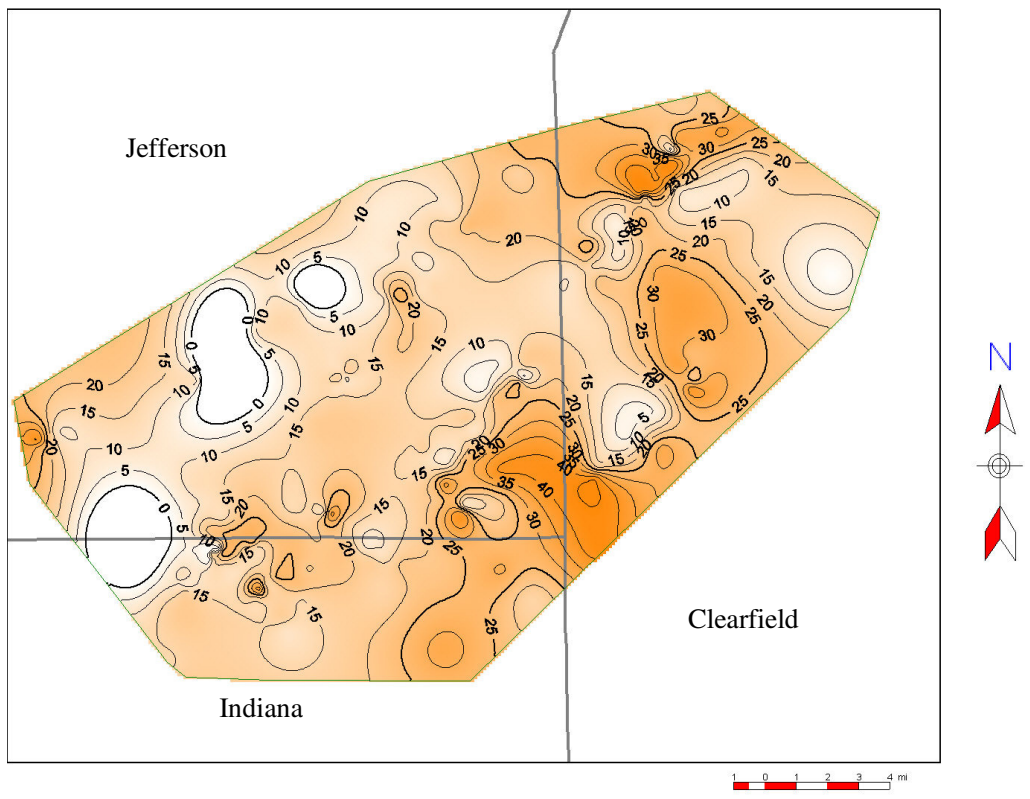

Figure 54-First Bradford Net-Pay Map

Reference: First Bradford net-sandstone map (Figure 28)

Contour Interval $=5 f t$ 
The Balltown zone net-pay maps (Figures 55-60) also show many of the same basic trends that are seen in the net-sandstone maps. However, the net-pay values for the Speechley beds tend to be notably thinner when compared to the net-sandstone values. The net-pay values of the Speechley are as much as ten feet thinner than the netsandstone values. This is due to the relative lack of porosity in these sandstones. Smosna and Bruner (1997) showed that depositional processes largely controlled the lack of porosity in the Lock Haven Formation in Clinton County, PA. They found that the sandstones with the greatest porosity were those deposited in mouth bar and shelf environments and had a moderate content of lithic fragments. The lithic fragments within the Lock Haven Formation allow for the creation of secondary porosity within the sandstones. However, if the lithic content is too high compaction of these ductile grains destroys the primary porosity necessary for the leaching of the grains (Smosna and Bruner, 1997). This interpretation is reflected in the sandstones of the Speechley beds where the shoreline had migrated relatively close to the study area, and with it increased the influence of the fluvial systems feeding the delta. Predictively, this would have caused the deposition of a higher quantity of lithic fragments, and therefore reduced the porosity seen within these sandstones. 


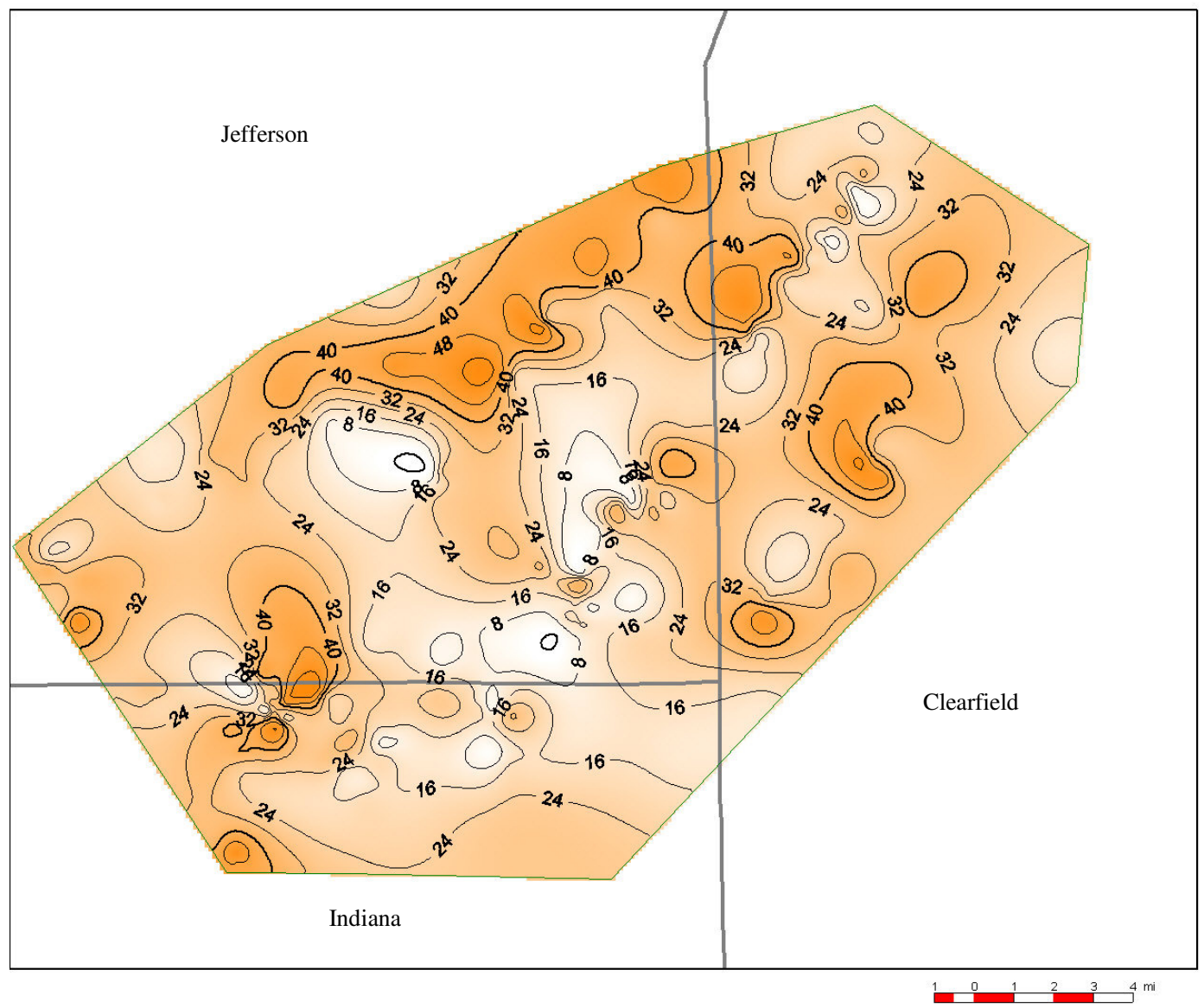

Figure 55-Balltown Zone Net-Pay Map

Reference: Balltown zone net-sandstone map (Figure 33)

Contour Interval $=8 f t$ 


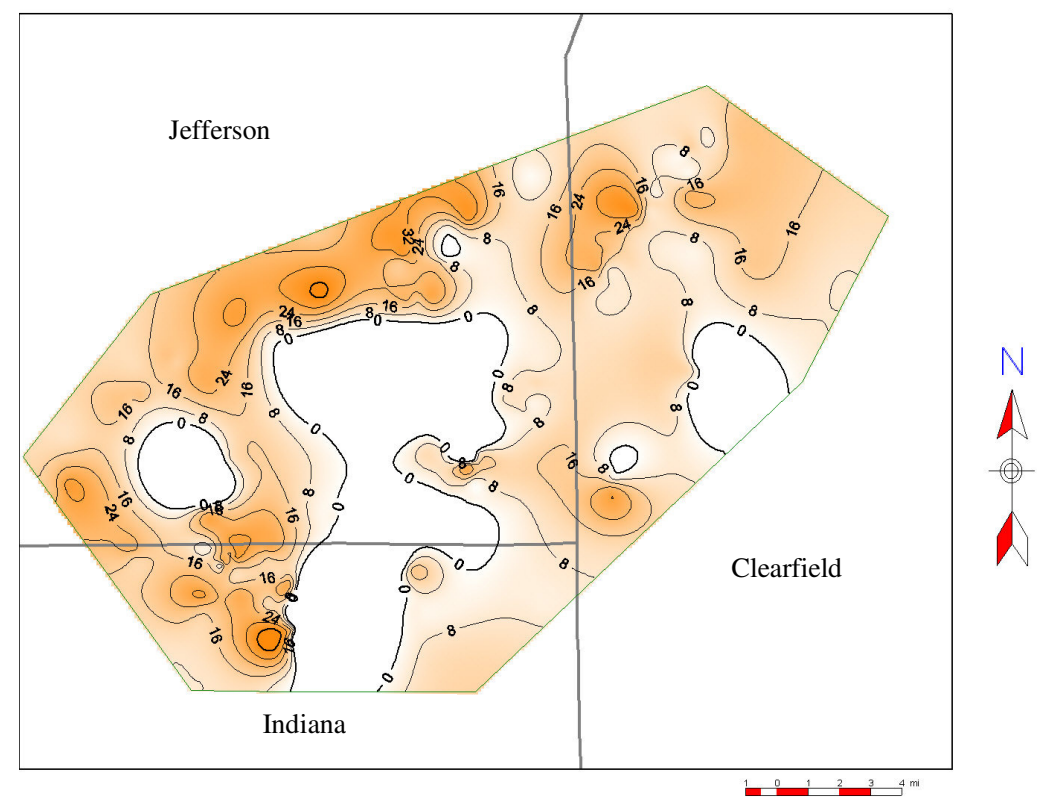

Figure 56-Balltown D Net-pay Map

Reference: Balltown D net-sandstone map (Figure 35)

Contour Interval $=8 f t$

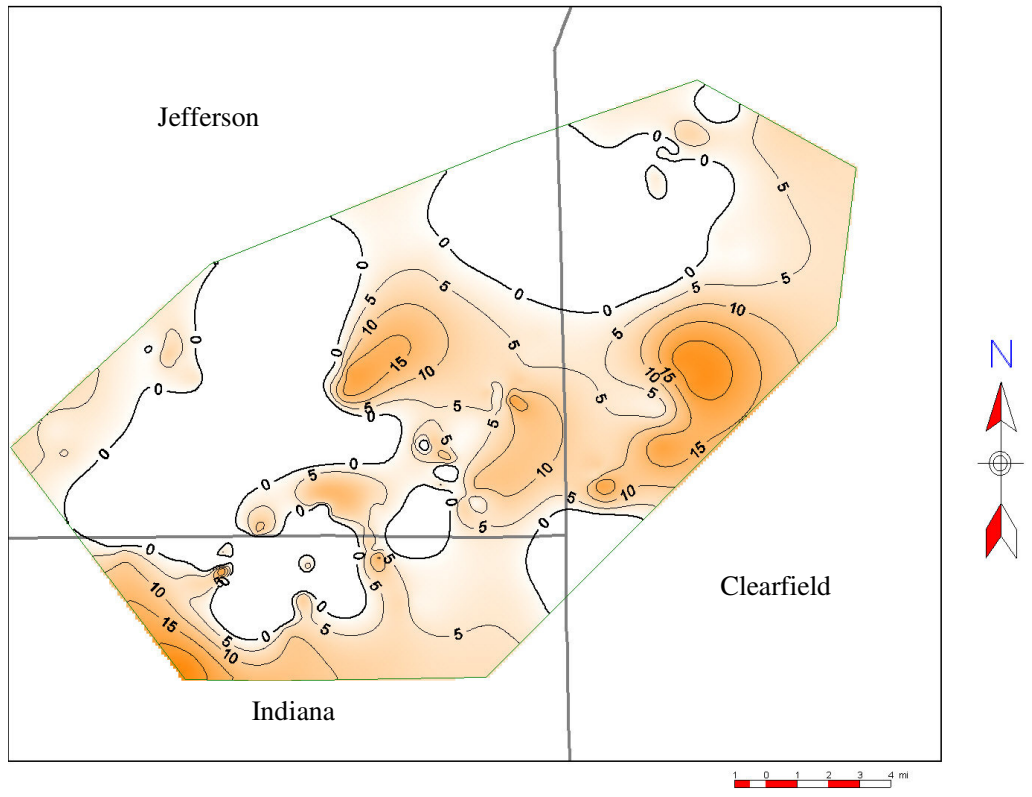

Figure 57-Balltown C Net-pay Map

Reference: Balltown C net-sandstone map (Figure 39)

Contour Interval $=5 f t$ 


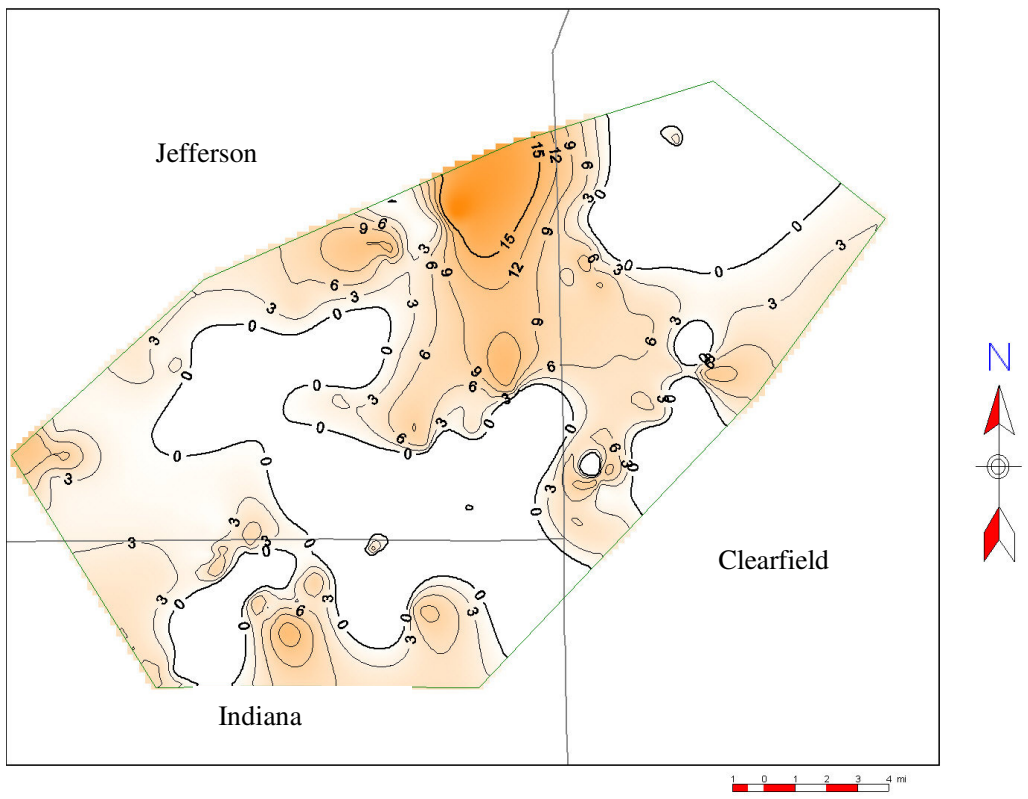

Figure 58-Balltown B Net-pay Map

Reference: Balltown B net-sandstone map (Figure 42)

Contour Interval $=3 f t$

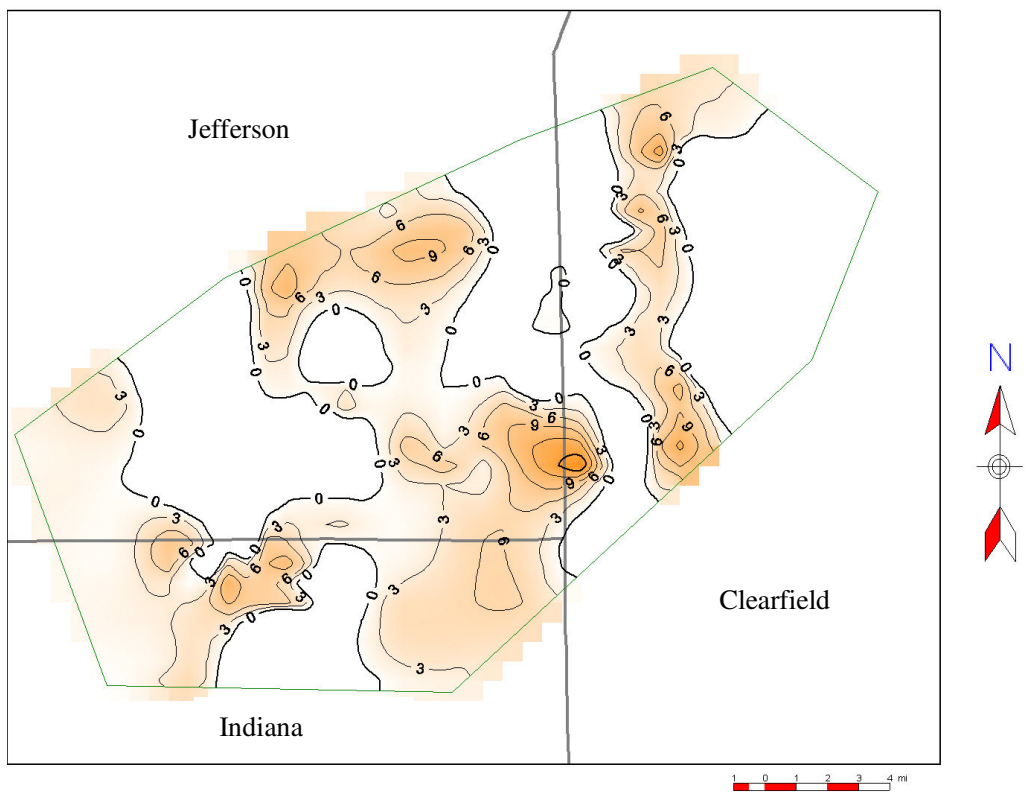

Figure 59-Balltown A Net-pay Map

Reference: Balltown A net-sandstone map (Figure 45)

Contour Interval $=3 f t$ 


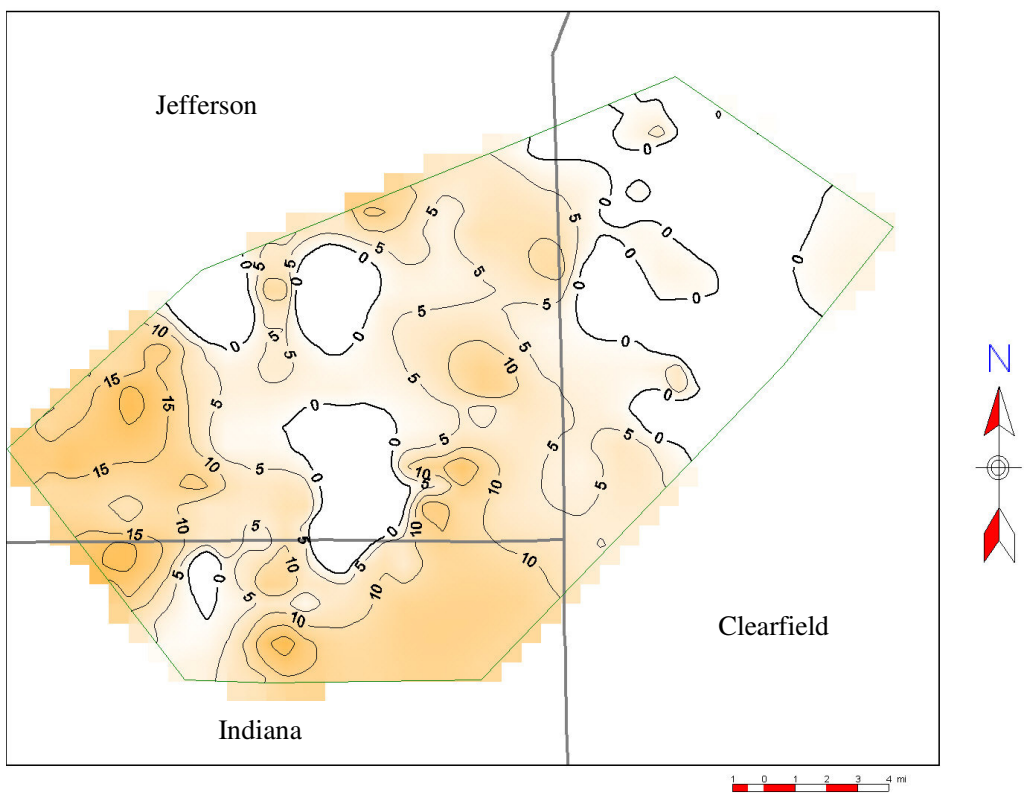

Figure 60-Speechley Net-pay Map

Reference: Speechley net-sandstone map (Figure 48)

Contour Interval $=5 f t$ 
The Bradford Group net-pay values as a whole indicate that the best locations for drilling appear to be located in the northern and eastern portions of the study area where values average around 100 feet thick (Figure 61). There is also good potential in the southwestern portion of the study area where net-pay values for the Bradford Group reach over 130 feet thick. However, net-pay values within the Bradford Group do not necessarily indicate the presence of a gas filled reservoir. Within the study area, some drillers' sandstones are known to be wet and when targeted produce water. Therefore, although the presence of porosity is necessary for a productive gas reservoir it is not entirely indicative of such, and sandstones should be individually evaluated for their economic potential. 


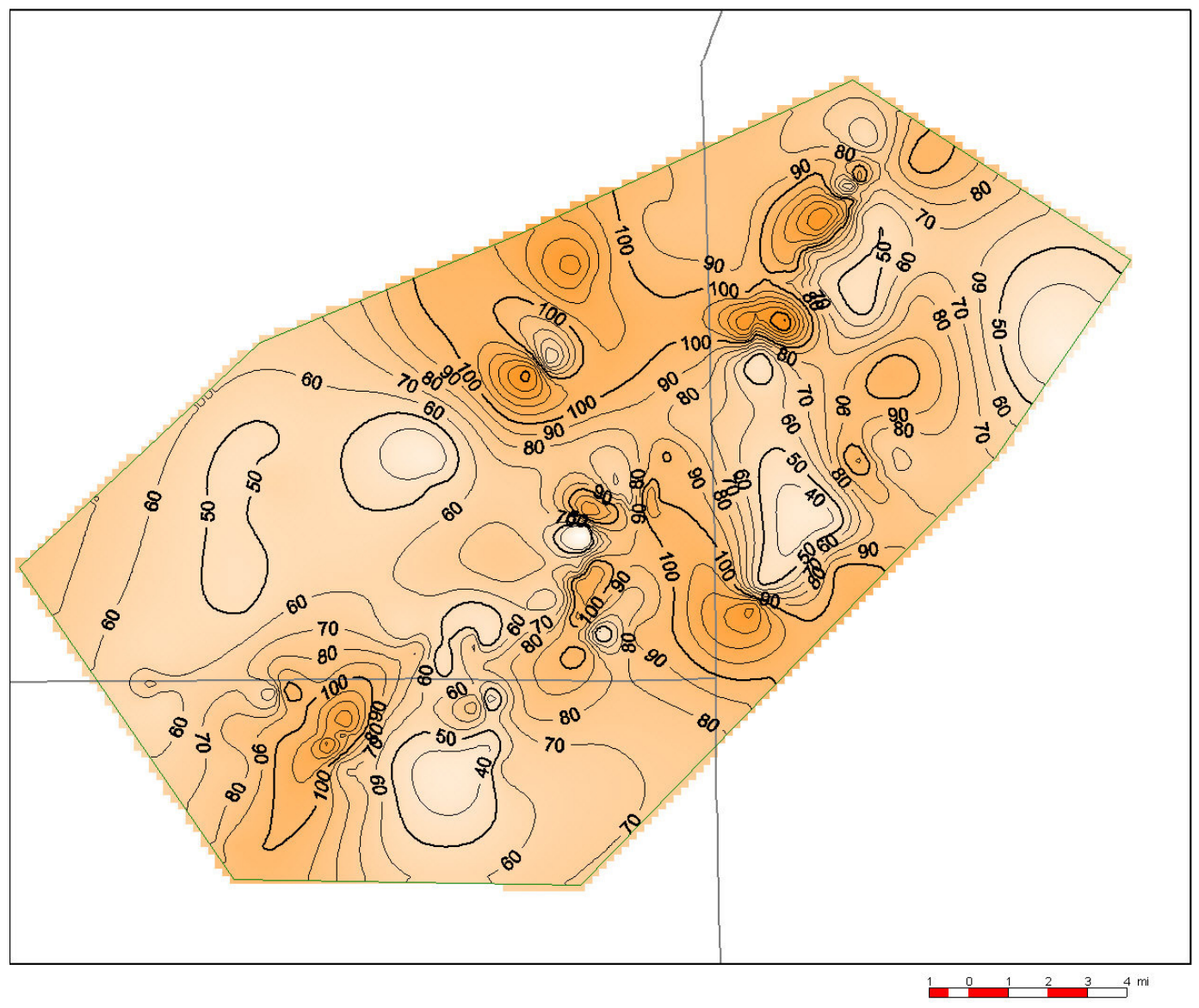

N

Figure 61-Bradford Group Net-pay Map

Contour Interval $=10 \mathrm{ft}$ 


\section{CONCLUSIONS}

The intent of this study was to apply the principles of sequence stratigraphy to the Bradford Group of west-central Pennsylvania in order to more accurately identify individual drillers' sandstones, as well as allow for the interpretation of the depositional environments in which these sandstones were deposited. Regionally correlative shales and other marker beds were used to correlate the individual drillers' sandstones on e-logs within the study area. Maps were then constructed based on net-sandstone values, netpay values, and the total thickness between marker beds. Cross sections were also constructed to show vertical variation and trends seen in both the strike and dip directions. The maps and cross section were used to not only show the location of sandstones and porosity within the study area, but also to interpret changes of relative sea level and the corresponding relationship of chronostratigraphic surfaces within the Bradford Group.

The two fourth order sequences recognized in the Bradford Group (Figure 62) are interpreted to be the result of the active deposition of sediment and the filling of accommodation space created by fluctuations in eustatic sea level. A fall of sea level in the Greater Punxsutawney area began at the base of the Bradford Group and is defined by the transition from deep-water basinal shales of the Brallier Group to the sandy turbidites of the Kane and Third Bradford beds. The contact between the Brallier Group and the Kane beds is interpreted as a correlative conformity that marked the onset of a forced regression of sea level and the FSST. The overlying First and Second Bradfords

comprise the LST. During the beginning of the LST, eustatic sea level had turned around and was beginning to rise, but the rate of sedimentation overwhelmed the influences of 
eustatic sea level rise. The normal regression of sea level caused the shoreline to the east to migrate farther basinward until the delta-front sandstone seen in the First Bradford prograded into the study area. The top of the First Bradford is marked by a flooding surface and the onset of the TST, which is composed of shales. During this time eustatic sea level rose at a rate that overwhelmed sedimentation rate, caused coarser sediment to be trapped in nearshore and fluvial systems, and allowed the basinal shale of the T1 beds to be deposited within the study area. The T1 marker bed, deposited within the T1 shale, is interpreted to be a maximum flooding surface at the end of the TST. The shale located above the T1 marker bed, therefore, belong to the HST of the Bradford zone. However, the HST within the study area is not well preserved due to the erosion by fluvial channels of the overlying Balltown zone that formed the unconformity and sequence boundary that separates the Bradford zone from the Balltown zone. 


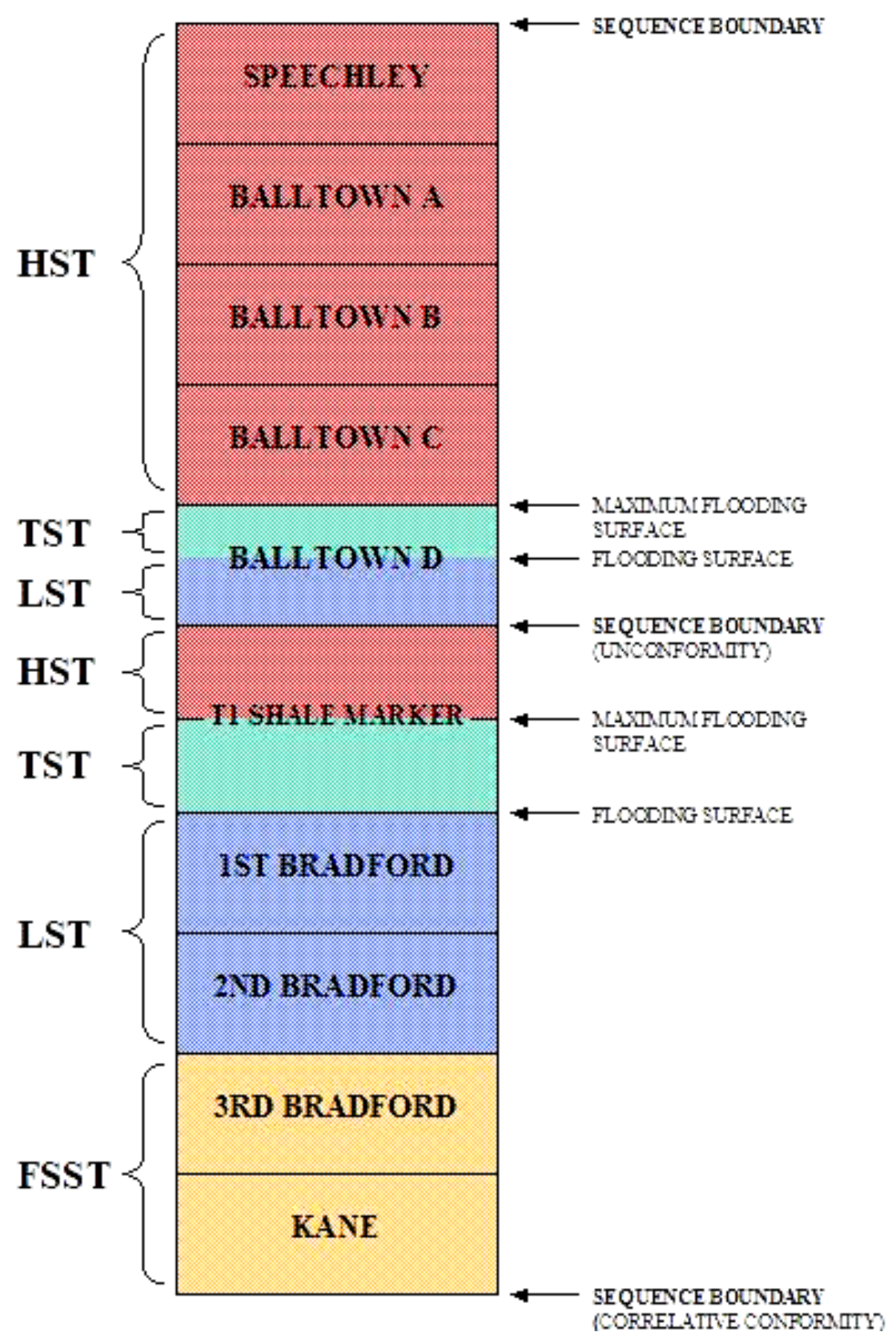

Figure 62-Sequence Stratigraphic Diagram of the Upper Devonian Bradford Group FSST = Falling Stage Systems Tract; LST = Lowstand Systems Tract; TST= Transgressive Systems Tract; HST = Highstand Systems Tract. 
The Balltown zone is composed of fluvial-deltaic deposits. The Balltown D beds overly the basal unconformity. The basal sandstone of the Balltown D beds is interpreted to be the LST. During which, the eustatic sea level fall that caused the formation of the unconformity had now began to rise, but was outpaced by the rate of sedimentation. This caused the infilling of the fluvial channels. The TST of the Balltown zone is composed entirely of the upper siltstone and shale package of the Balltown D beds that overlies the basal fluvial sandstones (of the LST). The top of the siltstone and shale package is interpreted to be a maximum flooding surface or maximum transgression of sea level in the Balltown zone. The HST of the Balltown zone consists of the Balltown C, Balltown B, Balltown A, and Speechley beds. The Balltown C beds are representative of a small prograding delta within the study area. Sandstones of the Balltown B show that progradation of the delta continued seaward as sediment filled accommodation space. However, the overlying Balltown A and Speechley show more of a lateral accumulation of sediment within the study area as the position of the delta shifted to the west. This lateral shift of sedimentation indicates a lack of accommodation space, and is supported by the transition from the deltaic deposits of the Balltown zone to the overlying red beds of the Catskill Formation.

This study has shown that by combining sequence stratigraphic principles with interpretations made by other authors, both depositional environments and reservoir characteristics can be interpreted and predicted. However, these interpretations and predictions are limited by the ability to identify geologically significant beds on e-logs and by the accuracy of the interpretations made by other authors. Despite these problems, this study does provide a methodology by which to both explore and develop gas 
reservoirs within west-central Pennsylvania more accurately and efficiently than previous studies. 


\section{REFERENCES}

Allen, P. A., Allen, John R., 2005, Basin Analysis: Principles and Applications, Blackwell Publishing Limited, 549 pg.

Boswell, R.M., 1988, Basin Analysis of Acadian Clastic Wedge in Northern West Virginia and Adjacent Areas: unpublished Ph. D. dissertation, West Virginia University, $351 \mathrm{p}$.

Boswell, R.M. and Donaldson, A.C., 1988, Depositional architecture of the Upper Devonian Catskill Delta Complex: central Appalachian Basin, U.S.A., Canadian Society of Petroleum Geologists, v. 14, p. 65-84.

Boswell, Ray M. and Jewell, Gregory A., 1988, Atlas of Upper Devonian/Lower Mississippian Sandstones in the Subsurface of West Virginia, West Virginia Geological and Economic Survey, Report: C-43, p. 143.

Boswell, Ray, Thomas, Bradley W., Hussing, R. Brandon, Murin, Timothy M., Donaldson, Alan, 1996, Upper Devonian Bradford Sandstones and Siltstones, West Virginia Geological and Economic Survey, Report: v. 25, p. 70-76.

Cant, Douglas J., 1996, Sedimentological and sequence stratigraphic srganization of a foreland clastic wedge, Western Canada Basin: Journal of Sedimentary Research, v. 66, no.6, p. 1137-1147.

Carter, Kristin M. and Harper, John A, 2002, Oil and gas prospects in northeastern Pennsylvania, in Inners, J.D., and Fleeger, G.M., eds., from Tunkahnnock to Starrucca: bluestone, glacial lakes, and great bridges in the "Endless Mountains" of northeastern Pennsylvania: Guidebook, $67^{\text {th }}$ Annual Field Conference of Pennsylvania Geologists, Tunkhannock, PA, p. 15-31.

Castle, James W., 2000, Recognition of facies, bounding surfaces, and stratigraphic patterns in foreland-ramp successions: an example from the Upper Devonian, Appalachian Basin, U.S.A.: Journal of Sedimentary Research, v. 70, no. 4, p. 896-912.

Castle, James W., 2001a, Appalachian Basin stratigraphic response to convergent-margin structural evolution, Basin Research, v.13, p. 397-418.

Castle, James W., 2001b, Foreland-basin sequence response to collisional tectonism, Geological Society of America Bulletin, v. 113, no. 7, p. 801-812.

Catuneanu, Octavian, 2006, Principles of Sequence Stratigraphy, Elsevier, Amsterdam, The Netherlands, $375 \mathrm{pg}$. 
Cecil, C. Blaine, Brezinski, David K., DuLong, Frank, 2004, The Paleozoic record of changes in global climate and sea level: central Appalachian Basin, Geology of the National Capital Region-Field Trip Guidebook, Geological Society of America, C. 1264, p. 77-135.

Cotter, Edward, Driese, Steven G., 1998, Incised-valley fills and other evidence of sealevel fluctuations affecting deposition of the Catskill Formation (Upper Devonian), Appalachian foreland basin, Pennsylvania, Journal of Sedimentary Research, v. 68, no. 2, p. 347-361.

Dalrymple, Robert W., Zaitlin, Brian A., and Boyd, Ron, Estuarine facies models; conceptual basis and stratigraphic implications, 1992, Journal of Sedimentary Research, v. 62, p. 1130-1146.

Demaison, G. and Moore, G. T., 1980, Anoxic environments and oil source bed genesis, AAPG Bulletin, v. 64, p. 1179-1209.

Demarest, J.M. and Kraft, J.C., 1987, Stratigraphic record of Quaternary sea levels: implications for more ancient strata, in Sea-level fluctuation and coastal evolution (Eds D. Nummedal, O.H. Pilkey and J.D. Howard), SEPM Spec. Publ., 41, p. 223-229.

Dennison, John M., 1985, Catskill delta shallow marine strata, Geological Society of America, v. 201, p. 91-106.

Ettensohn, F.R., 1985, The Catskill delta complex and the Acadian orogeny: a model, Geological Society of America Special Paper 201, p. 39-49.

Gautier, D.L., Dolton, G.L., Takahashi, K.I., and Varnes, K.L., 1995, 1995 national assessment of United States oil and gas resources-results, methodology, and supporting data: U.S. Geological Survey, Digital Data Series DDS-30 [CD-ROM].

Glaeser, J. D., 1974, Upper Devonian stratigraphy and sedimentary environments in northeastern Pennsylvania: Pennsylvania Geological Survey, $4^{\text {th }}$ Series, General Geology Report 63.

Hibbard, James P., 2004, The Appalachian orogen, in van der Pluijm, Ben A., Marshak, Stephen, Earth structure, W. W. Norton \& Company, Inc., p. 582-591.

Hussing, R. Brandon, 1994, Structure and Sedimentation of Upper Devonian Bradford Group "Kane" Sandstone of Cush Cushion Field, West-Central Pennsylvania: unpublished M.S. thesis, West Virginia University, Morgantown, 86p.

Johnson, J.G., Klapper, Gilbert, Sandberg, Charles A., 1985, Devonian eustatic fluctuations in Euramerica, Geological Society of America Bulletin, v. 96, no. 5, p. 567587. 
Kent, D.V., 1985, Paleocontinental setting for the Catskill delta, in Woodrow, D.L., and Sevon, W.D., eds., The Catskill Delta: Geological Society of America, Special Paper 201.

Laughrey, C. D. and Harper, J. A., 1986, Comparisons of Upper Devonian and Lower Silurian tight formations in Pennsylvania-geological and engineering characteristics, AAPG Bulletin, v. 24, p. 9-43.

Laughrey, Christopher D., Billman, Dan A., Canich, Michael R., 2004, Petroleum geology and geochemistry of the Council Run gas field, North Central Pennsylvania, AAPG Bulletin, v. 88, no. 2, p. 213-239.

McMillan, N. J., Embry, A. F., Glass, D.J., Devonian of the world; Proceedings of the Second International Symposium on the Devonian System, Canadian Society of Petroleum Geologists, Vol. 14.

Murin, Timothy Michael, 1988, Sedimentology and structure of the First Bradford sandstone in the Pennsylvanian Plateau province, unpublished M.S. thesis, University of Pittsburgh, Pittsburgh, 95pg.

Posamentier, Henry W., Jervey, M.T., and Vail, P.R., 1988, Eustatic controls on clastic deposition I-conceptual framework, in sea level changes-an integrated approach, SEPM Special Publication 42, p. 110-124.

Posamentier, Henry W., Allen, George P., James, David P., and Tesson, Michel, 1992, Forced regressions in a sequence stratigraphic framework: concepts, examples, and exploration significance, AAPG Bulletin, v. 76, No. 11, p. 1687-1709.

Posamentier, Henry W., Allen, George P., James, David P., 1992, High resolution sequence stratigraphy-the East Coulee Delta, Alberta, Journal of Sedimentary Petrology, v. 62, no. 2, p. 310-317.

Prothero, Donald R., Schwab, Fred, 1996, Sedimentary geology: an introduction to sedimentary rocks and stratigraphy, W.H. Freeman and Company, New York, 575 pg.

Quinlan, G. M. and Beaumont, C., 1984, Appalachian thrusting, lithospheric flexure, and the Paleozoic stratigraphy of the eastern interior of North America, in Appalachian basin stratigraphic response to convergent-margin structural evolution by J.W. Castle, Can. F. Earth Sci., 21, p. 973-996.

Reading, H. G. and Levell, B. K., 1996, Controls on the sedimentary rock record, in Sedimentary environments: processes, facies, and stratigraphy, Blackwell Science, London, p. 5-36.

Sevon, W. D. and Woodrow, D. L., 1985, Middle and Upper Devonian stratigraphy within the Appalachian basin, The Catskill delta: Geological Society of America, Special Paper 201, p. 1-7. 
Slingerland, Rudy and Loule, J.P., 1988, Wind-wave and tidal processes along Upper Devonian Catskill shoreline in Pennsylvania, U.S.A., Canadian Society of Petroleum Geologists Memoir 14, v. 2, p. 125-137.

Smosna, Richard and Bruner, Kathy R., 1997, Depositional controls over porosity development in lithic sandstones of the Appalachian basin: reducing exploration risk, in Kupecz, J.A., Gluyas, J., and Bloch, S., eds., Reservoir quality prediction in sandstones and carbonates: AAPG Memoir 69, p. 249-265.

Vail, P. R., Mitchum Jr., R. M., Thompson III, 1977, Seismic stratigraphy and global changes of sea level, part 3: Relative changes of sea sevel from coastal onlap, in C. E. Payton, ed., Seismic stratigraphy—applications to hydrocarbon exploration: AAPG Memoir 26, p. 63-97.

van der Pluijm, Ben A., Marshak, Stephen, 2004, Earth Structure: Second Edition, The Appalachian Orogen-An Essay by James P. Hibbard, W. W. Norton \& Company, Inc., p. 582-591.

Van der Voo, R., 1988, Paleozoic paleogeography of North America, Gondwana, and intervening displaced terranes: comparisons of paleomagnetism with paleoclimatology and geographical patterns: Geological Society of America Bulletin, v. 100, p. 311-324.

Van Tassell, Jay, 1987, Upper Devonian Catskill delta margin cyclic sedimentation: Brallier, Scherr and Foreknobs Formations of Virginia and West Virginia: Geological Society of America Bulletin, v. 99, p. 414-426.

Van Wagoner, J. C., Mitchum, R.M. Jr., Campion, K.M., and Rahmanian, V.D., 1990, Siliciclastic sequence stratigraphy in well logs, cores, and outcrops: concepts for highresolution correlation of time and facies, American Association of Petroleum Geologists, 55 pgs.

Walker, Roger G., 1971, Nondeltaic depositional environments in the Catskill clastic wedge (Upper Devonian) of central Pennsylvania, Geological Society of America Bulletin, v. 82, no. 5, p. 1305-1326.

Walker, Roger G., Harms, J.C., 1971, The 'Catskill Delta': a prograding muddy shoreline in central Pennsylvania, Journal of Geology, v. 79, no. 4, p. 381-399.

Walker, Roger G., 1992, Facies, facies models, and modern stratigraphic concepts, Facies Models, p. 1-14.

Walker, R.G. and Plint, A.G., 1992, Wave- and storm-dominated shallow marine systems, in Facies Models: Response to sea level change (Ed. by R. G. Walker and N. P. James),. Geological Association of Canada, p. 219-238. 
Warne, Andrew G., McGhee Jr., George R., 1991, Stratigraphic subdivisions of the Upper Devonian Scherr, Foreknobs, and Lock Haven Formations near the Allegheny front of central Pennsylvania; Northeastern Geology, v. 13, no. 2, p. 96-109.

White, David A., 1980, Assessing oil and gas plays in facies-cycle wedges, AAPG Bulletin, v. 64, no. 8, p. 1158-1178.

Woodrow, D.L. \& Sevon, W.D., 1985, eds., The Catskill delta, Geological Society of America, Special Paper 201.

Woodrow, D. L., Dennison, J. M., Ettensohn, Frank R., Sevon, W.T., Kirchgasser, W. T.,1988, Middle and Upper Devonian stratigraphy and paleontology of the southern Appalachians and eastern midcontinent, U.S.A., Canadian Society of Petroleum Geologists, v. 14, p. 277-301.

Woodrow, Donald L. and Fletcher, Frank W., 2002, Late Devonian stratigraphy in northeastern Pennsylvania, or, Devonian subdividin' and correlatin', in Inners, J.D., and Fleeger, G.M., eds., from Tunkhannock to Starrucca: bluestone, glacial lakes and great bridges in the "Endless Mountains" of northeastern Pennsylvania: Guidebook, $67^{\text {th }}$ Annual Field Conference of Pennsylvania Geologists, Tunkhannock, PA, p. 1-7.

Wright, V.P., Marriott, S.B., 1993, The sequence stratigraphy of fluvial depositional systems: the role of floodplain sediment storage, Journal of Sedimentary Geology, v. 86, p. 203-210. 